\title{
Instytut Hematologii i Transfuzjologii - działalność naukowa, lecznicza i diagnostyczna
}

\section{Wprowadzenie}

Instytut Hematologii i Transfuzjologii działa na podstawie ustawy z 30 kwietnia 2010 roku o instytutach badawczych (Dz. U. z 2016 r., nr 371 ze zm.), ustawy z 30 kwietnia 2010 roku - Przepisy wprowadzające ustawy reformujące system nauki (Dz. U. z 2010 r., nr 620 ze zm.), ustawy z 15 kwietnia 2011 roku o działalności leczniczej (Dz. U. z 2015 r., nr 618, ze zm.), ustawy z 22 sierpnia 1997 roku o publicznej służbie krwi (Dz. U. z 2014 r., nr 332, ze zm.) oraz rozporządzenia Rady Ministrów z 2 czerwca 1951 r. w sprawie utworzenia Instytutu Hematologii (Dz. U. z 1951 r., nr 35, poz. 268) i zarządzenia ministra zdrowia i opieki społecznej z 28 lutego 1992 r. w sprawie zmiany nazwy Instytutu Hematologii. Nadzór nad działalnością Instytutu sprawuje minister właściwy do spraw zdrowia.

Instytut Hematologii i Transfuzjologii jest państwową jednostką organizacyjną mającą osobowość prawną. Jest zarejestrowany w Sądzie Rejonowym dla m. st. Warszawy, w XIII Wydziale Gospodarczym Krajowego Rejestru Sądowego pod nr. 0000119139, oraz w Rejestrze Podmiotów Wykonujących Działalność Leczniczą prowadzonym przez wojewodę mazowieckiego (nr księgi rejestrowej: 000000018630). Instytutowi Hematologii i Transfuzjologii nadano NIP 525-000-94-24 i REGON 0002888484. Siedzibą Instytutu jest Warszawa. Instytut ma prawo używania okrągłej pieczęci $z$ wizerunkiem godła Rzeczypospolitej Polskiej pośrodku i napisem Instytut Hematologii i Transfuzjologii w otoku.

Instytut Hematologii i Transfuzjologii ma uprawnienia do nadawania stopni naukowych doktora i doktora habilitowanego oraz do prowadzania postępowania o nadanie tytułu naukowego profesora na podstawie odrębnych przepisów.

Organami Instytutu są Dyrektor i Rada Naukowa. Dyrektor zarządza Instytutem przy pomocy zastępców do spraw: naukowych, lecznictwa, trans- fuzjologii, zarządzania i ekonomiczno-finansowych, a także kierowników komórek organizacyjnych i samodzielnych stanowisk. Rada Naukowa jest organem stanowiącym, inicjującym, opiniodawczym i doradczym Instytutu w zakresie jego działalności statutowej oraz w sprawach rozwoju kadr naukowej i badawczo-technicznej.

\section{Jednostki organizacyjne}

Zgodnie ze znowelizowanymi w 2016 roku Statutem i Regulaminem Organizacyjnym Instytutu Hematologii i Transfuzjologii pion leczniczy tworzy obecnie 5 klinik: Klinika Hematologii, Klinika Zaburzeń Hemostazy i Chorób Wewnętrznych, Klinika Transplantacji Komórek Krwiotwórczych, Klinika Chirurgii Ogólnej, Onkologicznej i Metabolicznej, Klinika Chirurgii Naczyniowej, a także Oddział Anestezjologii i Intensywnej Terapii, Oddział Leczenia Dziennego oraz Blok Operacyjny. Jednostkami pomocniczymi są Przychodnia Specjalistyczna, Izba Przyjęć i Apteka.

W skład Instytutu Hematologii i Transfuzjologii wchodzi również 8 zakładów naukowych $z$ pracowniami diagnostycznymi i naukowymi, w tym: Zakład Transfuzjologii, Zakład Diagnostyki Hematologicznej, Zakład Hemostazy i Chorób Metabolicznych, Zakład Immunologii Hematologicznej i Transfuzjologicznej, Zakład Wirusologii, Zakład Immunogenetyki, Zakład Radiologii oraz Zakład Hematologii Doświadczalnej.

Ponadto w Instytucie istnieją liczne komórki działalności pomocniczej i obsługi służące utrzymaniu działalności wymienionych komórek podstawowych, którymi są działy, sekcje, biblioteka i samodzielne stanowiska pracy (ryc. 1).

\section{Pracownicy}

Ogółem liczba zatrudnionych w Instytucie osób wynosi obecnie 665 , w tym 88 lekarzy i 209 pielęgniarek. Na stanowiskach naukowych 


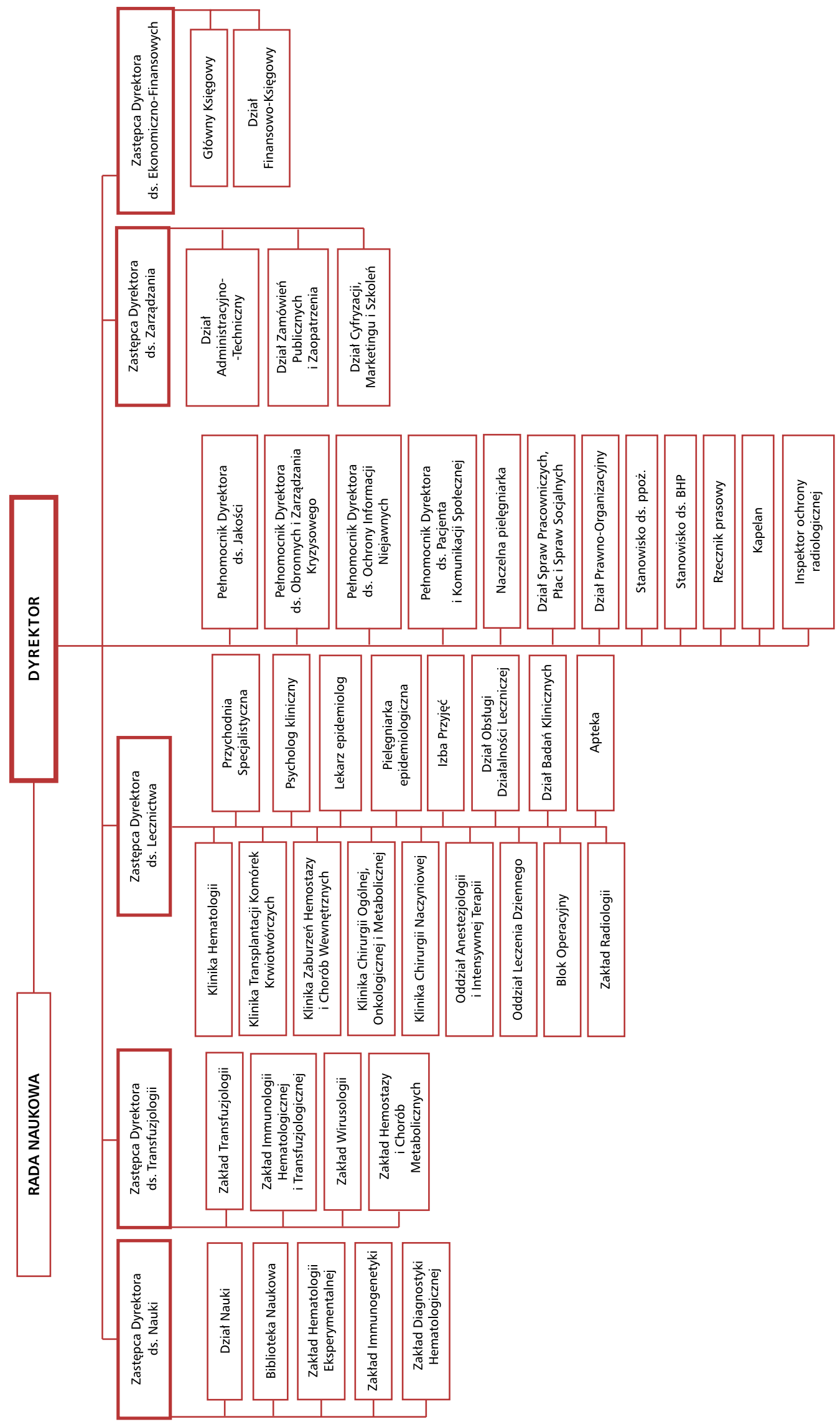

Rycina 1. Schemat organizacyjny Instytutu Hematologii i Transfuzjologii 


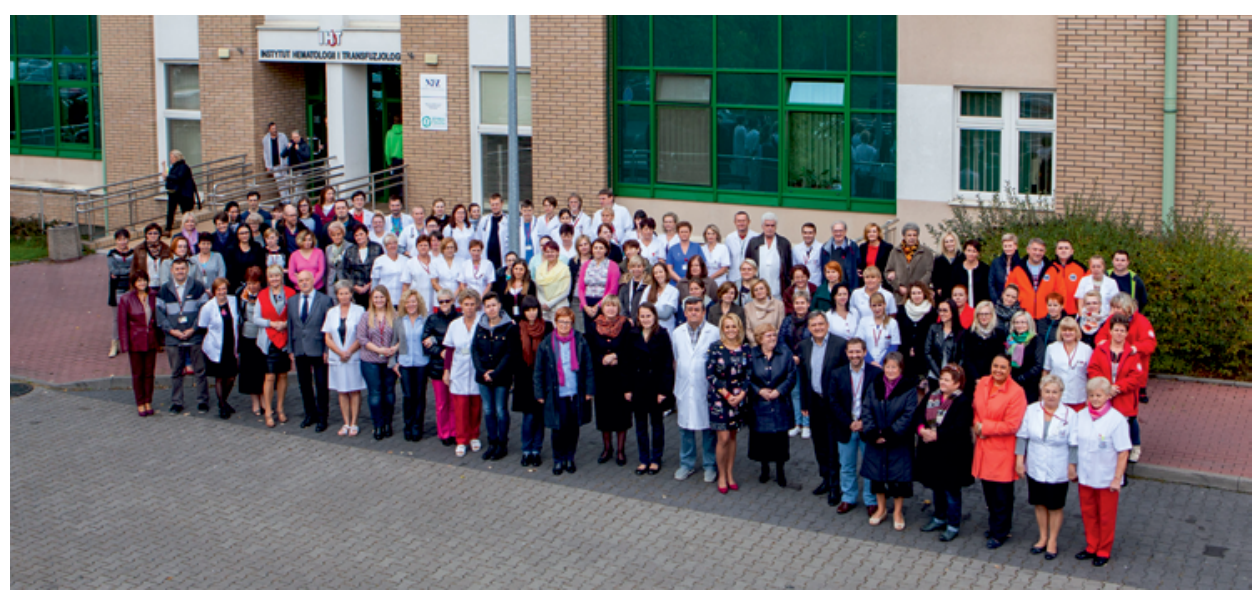

Rycina 2. 65-lecie Instytutu Hematologii i Transfuzjologii — wspólne zdjęcie pracowników

zatrudnione są 43 osoby, w tym 9 profesorów zwyczajnych, 6 profesorów nadzwyczajnych $z$ tytułem naukowym doktora habilitowanego, 23 adiunktów i 5 asystentów (ryc. 2).

Najdłużej pracującym w Instytucie pracownikiem był profesor Jerzy Kościelak, który został zatrudniony 1 września 1951 jako wolontariusz, a następnie przez kilkadziesiąt lat pełnił $\mathrm{w}$ nim funkcje sekretarza naukowego i kierownika $\mathrm{Za}-$ kładu Biochemii, a następnie przez wiele lat, aż do czasu przejścia na emeryturę 31 grudnia 2007 roku, pełnił funkcję zastępcy dyrektora Instytutu do spraw naukowo-badawczych. Obecnie osobą o najdłuższym stażu pracy w Instytucie jest Pani mgr Marianna Jońska, która przeszła tutaj wszystkie etapy kariery zawodowej, poczynając od stanowiska księgowej (1965 r.), zastępcy głównego księgowego (1976 r.), głównego księgowego (1985 r.) i zastępcy dyrektora ds. ekonomiczno-finansowych (2003-2016 r.).

\section{Misja}

Misją Instytutu Hematologii i Transfuzjologii jest udzielanie wysokospecjalistycznych świadczeń zdrowotnych oraz prowadzenie badań naukowych i prac rozwojowych dla postępu nauki w zakresie hematologii, transfuzjologii i dyscyplin pokrewnych, przy zachowaniu dbałości o przyjazne i bezpieczne warunki pobytu pacjentów i pracy personelu.

Instytut Hematologii i Transfuzjologii posiada - certyfikowany od 2008 roku - Zintegrowany System Zarządzania Jakością, Zarządzania Środowiskowego i Zarządzania Bezpieczeństwem i Higieną Pracy według norm: ISO 9001, ISO 14001, OHSAS 18001. W dniu 11 maja 2015 roku minister zdrowia przyznał Instytutowi Certyfikat Akredytacyjny potwierdzający nakierowanie wszystkich działań bezpośrednio na bezpieczeństwo pacjentów, pracowników oraz osób przebywających na terenie Instytutu, a tym samym spełnienie wymagań standardów przewidzianych dla lecznictwa zamkniętego. Proces przygotowania do akredytacji odbył się w ramach drugiej edycji naboru do realizowanego przez Centrum Monitorowania Jakości w Ochronie Zdrowia projektu „Bezpieczny szpital — bezpieczny pacjent".

Instytut Hematologii i Transfuzjologii od 5 lat utrzymuje się w ścisłej czołówce ogólnopolskiego rankingu „Bezpieczny Szpital” prowadzonego przez „Rzeczypospolitą”. W 2015 roku po raz kolejny uzyskał pierwsze miejsce w województwie mazowieckim wśród wszystkich ocenianych placówek służby zdrowia oraz drugą lokatę w Polsce w kategorii monospecjalistycznych szpitali zabiegowych.

\section{Działalność diagnostyczna i lecznicza}

Instytut Hematologii i Transfuzjologii podpisał w 2015 roku 7 umów z Mazowieckim Oddziałem Narodowego Funduszu Zdrowia na udzielanie świadczeń zdrowotnych na łączną kwote 123237 962,18 zł. W ramach tych umów w klinikach i na oddziałach Instytutu przeprowadzono 13583 hospitalizacji, w poradniach Przychodni Specjalistycznej udzielono 48921 porad ambulatoryjnych, a w zakładach i pracowniach naukowych wykonano 916707 badań diagnostycznych.

W ostatnich latach działalności statutowej Instytutu Hematologii i Transfuzjologii obserwuje się ustawiczny wzrost przychodów $z$ tytułu działalności operacyjnej, w tym przede wszystkim w związku $z$ realizacją zwiększonej liczby wysokospecjalistycznych świadczeń medycznych 
i badań klinicznych, projektów i grantów naukowych krajowych i zagranicznych oraz $\mathrm{w}$ związku $z$ wykonywaniem dla podmiotów zewnętrznych komercyjnych badań specjalistycznych, ocen, ekspertyz i innych. Utrzymująca się dobra kondycja finansowa Instytutu pozwoliła nie tylko na utrzymanie płynności finansowej - Instytut nie miał i nie ma zobowiązań wymagalnych - ale także na wypracowanie nadwyżki finansowej w 2015 roku. Ta sytuacja pozwala aplikować o środki zewnętrzne na inwestycje, zwłaszcza $z$ programów operacyjnych Unii Europejskiej perspektywy finansowej 2014-2020. Czynione są starania o pozyskanie funduszy między innymi na budowę pawilonu naukowo-diagnostycznego w siedzibie na Ursynowie mogącego pomieścić pracownie i zakłady naukowe zlokalizowane obecnie przy ul. Chocimskiej 5.

\section{Działalność naukowa}

Wynikiem działalności naukowej pracowników Instytutu Hematologii i Transfuzjologii są liczne publikacje i doniesienia naukowe przedstawiane na konferencjach i zjazdach w kraju i za granicą. Całkowita liczba publikacji pełnotekstowych w ostatnich 5 latach wyniosła 524 (łączny Impact Factor [IF] 1069, liczba cytowań 2613, indeks Hirscha 19), 19 monografii i podręczników oraz 177 rozdziałów w publikacjach zbiorowych. Dodatkowo w tym czasie opublikowano 1254 streszczeń przesłanych na konferencje lub zjazdy naukowe, krajowe bądź zagraniczne, w postaci plakatów lub wystąpień ustnych oraz zrealizowano 12 grantów krajowych i 5 grantów unijnych.

Pracownicy Instytutu Hematologii i Transfuzjologii aktywnie uczestniczą w realizacji badań naukowych prowadzonych przez Polską Grupę Białaczkową u Dorosłych, Polską Grupę Badawczą Chłoniaków, Polską Grupę Szpiczakową i Polską Grupę ds. Hemostazy oraz wchodzą w skład osobowy ich Zarządów. Od 1970 roku, wspólnie, z Polskim Towarzystwem Hematologów i Transfuzjologów, Instytut wydaje periodyk „Acta Haematologica Polonica”, a także, od 2008 roku - kwartalnik "Journal of Transfusion Medicine” (red. M. Łętowska) i od 2010 roku — kwartalnik „Hematologia” (red. K. Warzocha).

Wszechstronna i twórcza aktywność naukowa i edukacyjna Pracowników Instytutu jest od lat wysoko oceniana przez Komitet Ewaluacji Jednostek
Ministerstwa Nauki i Szkolnictwa Wyższego, który od początku prowadzenia przedmiotowej kategoryzacji (2010 r.) przyznaje Instytutowi Hematologii i Transfuzjologii kategorię A.

\section{Działalność edukacyjna}

Od wielu lat Pracownicy Instytutu Hematologii i Transfuzjologii aktywnie uczestniczą we wspó1redagowaniu czasopism i monografii o charakterze zaleceń diagnostyczno-leczniczych w chorobach krwi, onkologii, transfuzjologii klinicznej i laboratoryjnej. Między innymi współtworzyli, jako współredaktorzy i autorzy rozdziałów, następujące opracowania: „Zalecenia diagnostyczno-terapeutyczne w nowotworach złośliwych” (red. M. Krzakowski i K. Warzocha, Via Medica, Gdańsk 2013), „Onkologia kliniczna” (red. M. Krzakowski, P. Potemski, K. Warzocha, P. Wysocki, Via Medica, Gdańsk 2015), „Hematologia” (red. T. Robak i K. Warzocha, Via Medica, Gdańsk 2016), „Medyczne zasady pobierania krwi, oddzielania jej składników i wydawania obowiązujące w jednostkach organizacyjnych publicznej służby krwi”(red. M. Łętowska, IHT, Warszawa, 2011 i 2014).

Ważną formą działalności Instytutu Hematologii i Transfuzjologii jest organizowanie, często we współpracy z innymi ośrodkami, konferencji naukowych i kursów szkoleniowych. Od 10 lat Instytut patronuje ogólnopolskiej konferencji po ASH, stanowiącej przegląd najważniejszych wyników badań naukowych publikowanych $\mathrm{w}$ trakcie corocznych konferencji Amerykańskiego Towarzystwa Hematologicznego. Od 7 lat patronuje także corocznej ogólnopolskiej konferencji edukacyjnej czasopisma „Hematologia” oraz cyklowi regionalnych spotkań naukowych pod nazwą „Hematologia i Hemostaza”.

W 2013 roku w strukturach Instytutu została utworzona, pod kierunkiem profesor Ewy Lech-Marańdy, Klinika Hematologii i Transfuzjologii Centrum Medycznego Kształcenia Podyplomowego, prowadząca kształcenie podyplomowe dla lekarzy specjalizujących się w dziedzinie hematologii i transfuzjologii klinicznej. Instytut jest także ośrodkiem szkoleniowo-dydaktycznym dla lekarzy specjalizujących się w chorobach wewnętrznych, transplantologii oraz dla diagnostów laboratoryjnych specjalizujących się w laboratoryjnej transfuzjologii i hematologii medycznej. 
Hematologia 2016, tom 7, suplement A

\section{DYREKCJA}
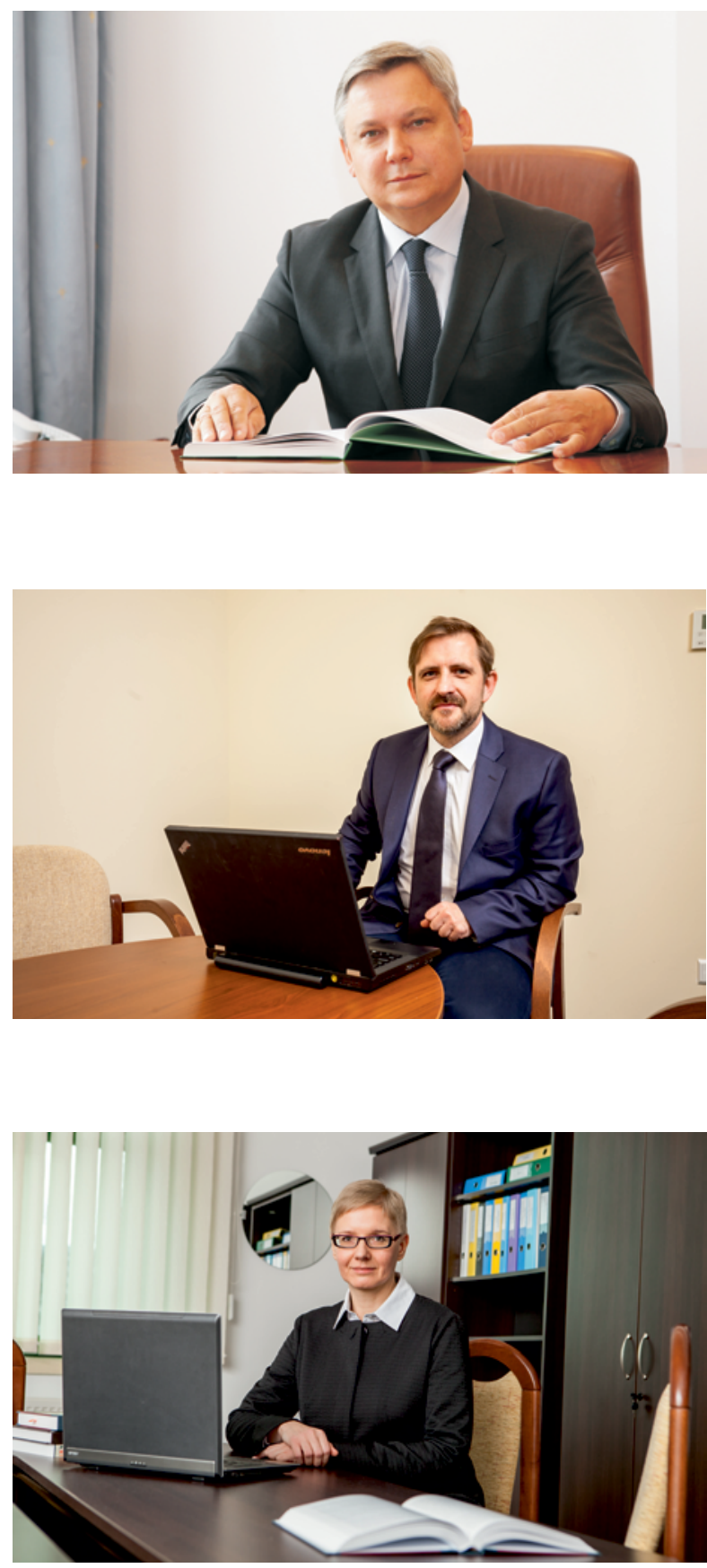

\section{Dyrektor Instytutu}

prof. dr hab. n. med. Krzysztof Warzocha

Sekretariat: Anna Ścibor

tel.: 223496 176; 223496179

faks 223496178

e-mail: sekihit@ihit.waw.pl

\section{Zastępca Dyrektora ds. Nauki}

dr hab. n. med. Przemysław Juszczyński, prof. nadzw.

Sekretariat: mgr Monika Milczarek-Szpak

tel. 223496305

faks 223496237

e-mail: mmilczarekszpak@ihit.waw.pl

\section{Zastępca Dyrektora ds. Lecznictwa} prof. dr hab. n. med. Ewa-Lech-Marańda

Sekretariat: Ilona Lesiak

tel. 223496527

faks 223496361

e-mail: lecznictwo@ihit.waw.pl 

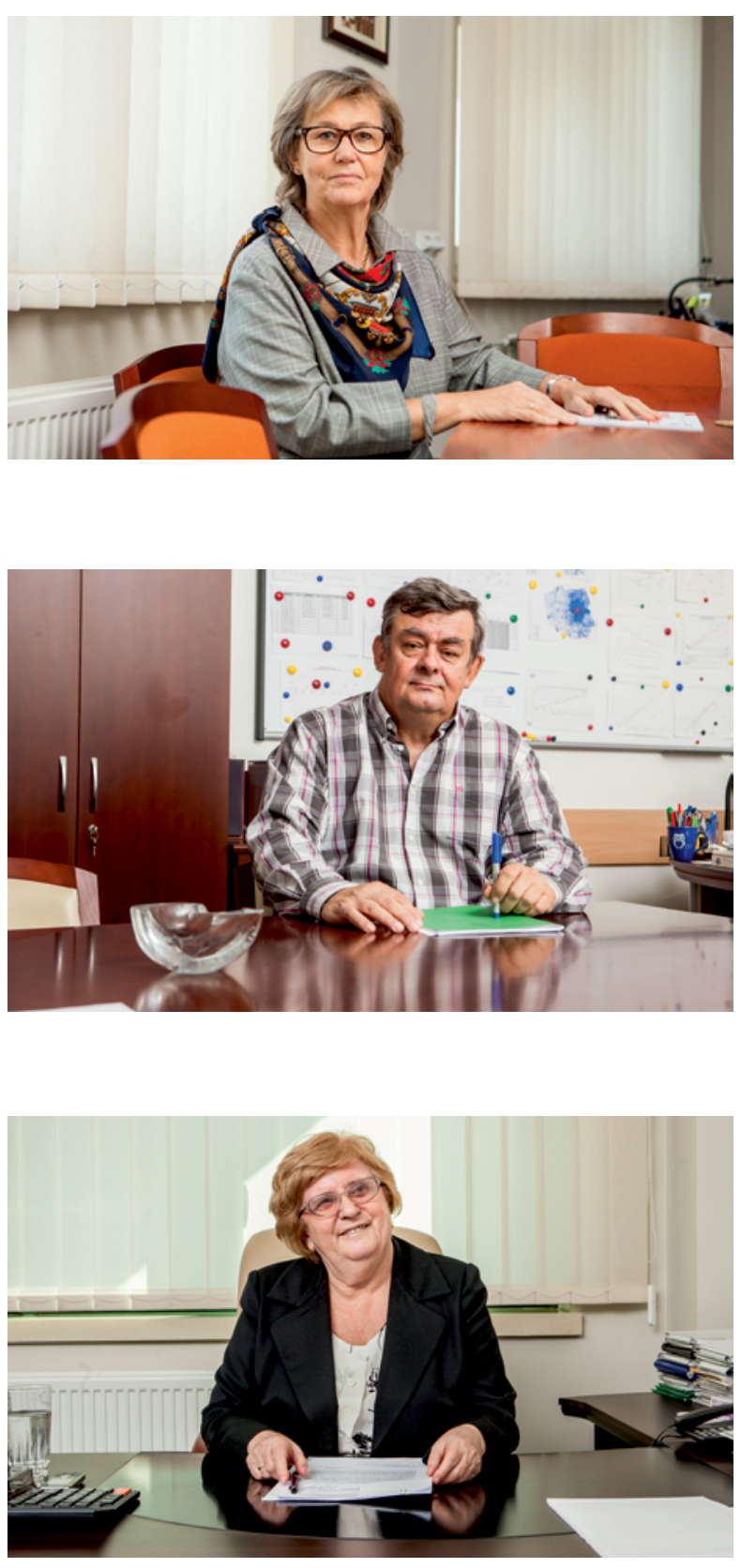

\section{Zastępca Dyrektora ds. Transfuzjologii} prof. dr hab. n. med. Magdalena Łętowska Sekretariat: Żaneta Mioduszewska tel. 223496371

faks 223496372

e-mail: bloodorg@ihit.waw.pl

Zastępca Dyrektora ds. Zarządzania mgr Witold Kmiotek

Sekretariat: Edyta Berska

tel.: 223496 177; 223496103

faks 223496178

e-mail: eberska@ihit.waw.pl

Zastępca Dyrektora ds. Ekonomiczno-Finansowych mgr Marianna Jońska

Sekretariat: mgr Danuta Stachowska tel.: 223496 187; 223496188 e-mail: mjonska@ihit.waw.pl

\section{Naczelna pielęgniarka}

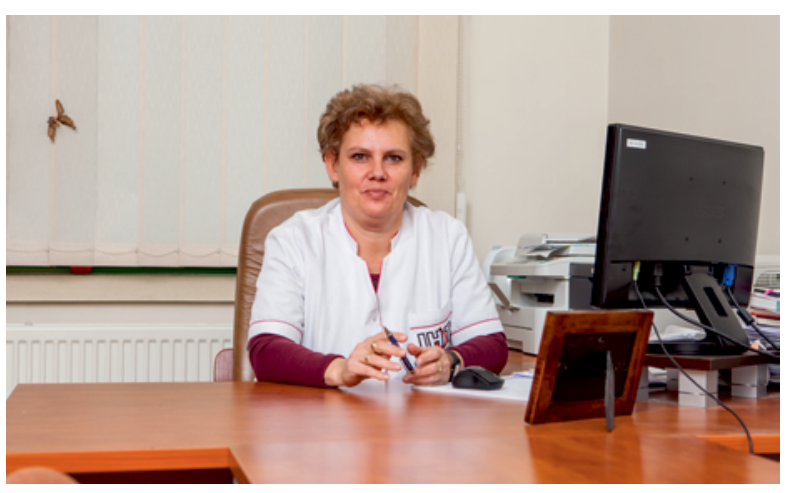

mgr Barbara Włodarczyk

Adres: ul. Indiry Gandhi 14, 02-776 Warszawa tel.: 223496 242; 223496244

faks: 223496243

e-mail: barbaraw@ihit.waw.pl 


\section{ADMINISTRACJA}

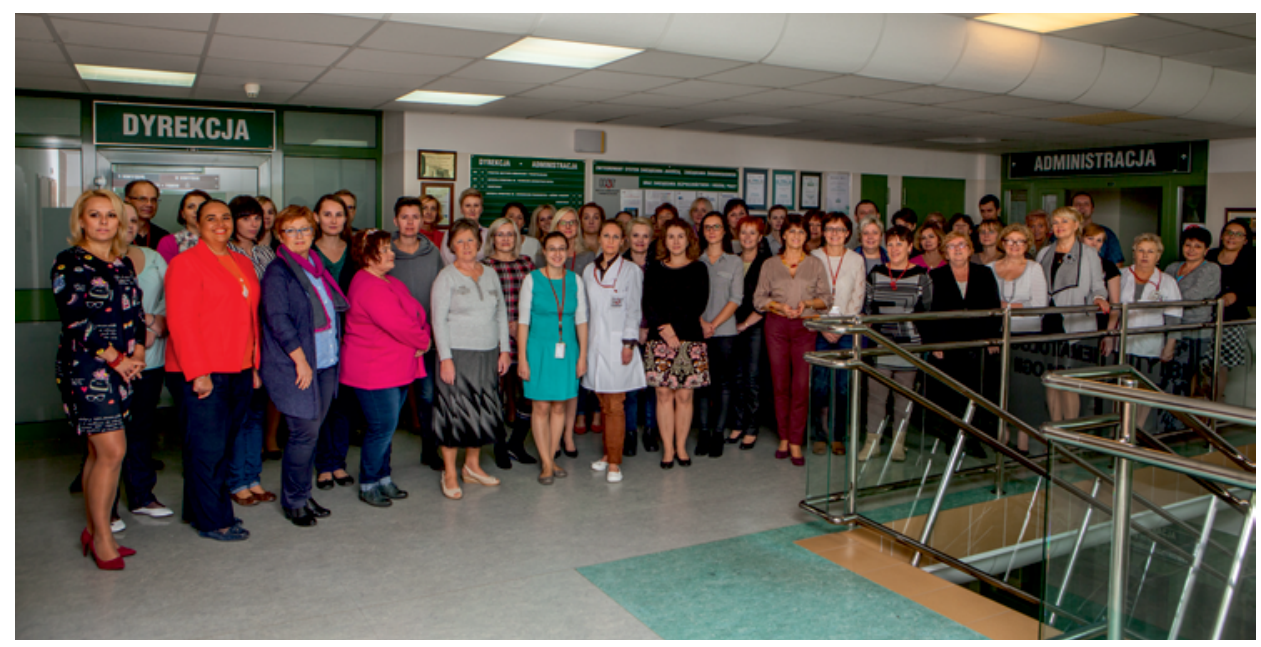

Dział Nauki

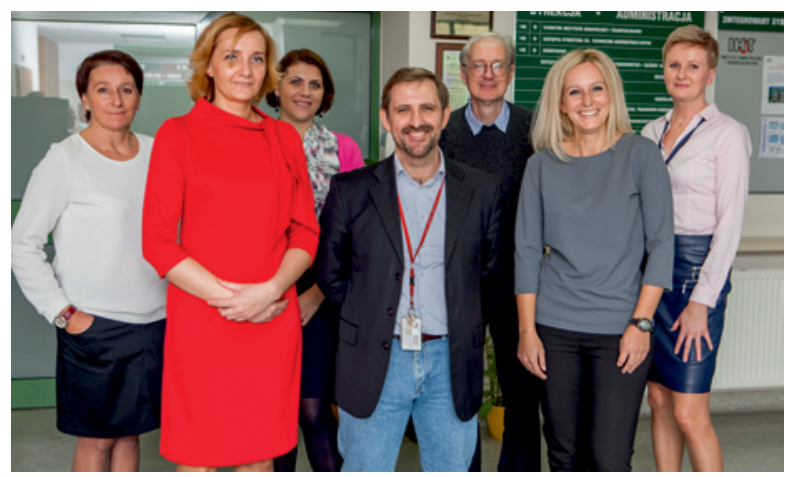

Kierownik: inż. Iwona Niebudek

tel.: 223496 233; 223496 235; 223496236

faks 223496237

e-mail: hematol@ihit.waw.pl

\section{Biblioteka}

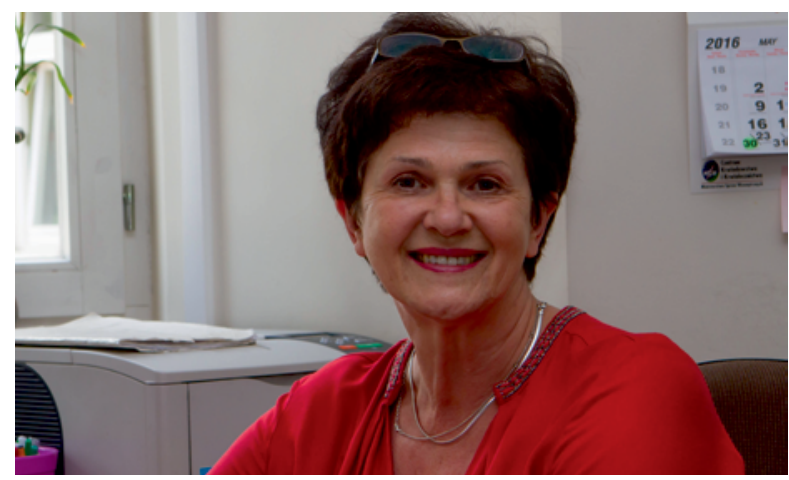

Kierownik: mgr Ewa Gierula-Uchmańska

tel.: 223496 486; 223496489

e-mail: biblioteka@ihit.waw.pl

\section{Dział Badań Klinicznych}

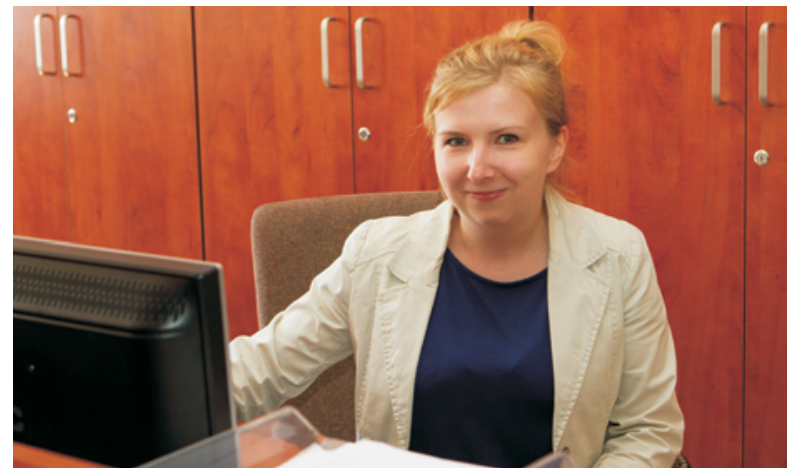

Kierownik: mgr Małgorzata Makowska tel. 223496454

faks 223496335

\section{Dział Obsługi Działalności Leczniczej}

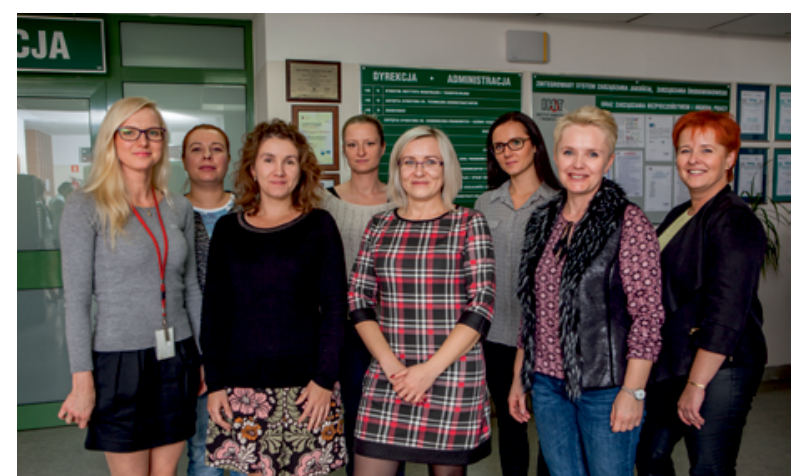

Kierownik: mgr Dorota Łęcka

tel.: 223496 217; 223496 466; 223496219

faks 223496218

e-mail: dol@ihit.waw.pl 


\section{Dział Spraw Pracowniczych, Płac i Spraw Socjalnych}

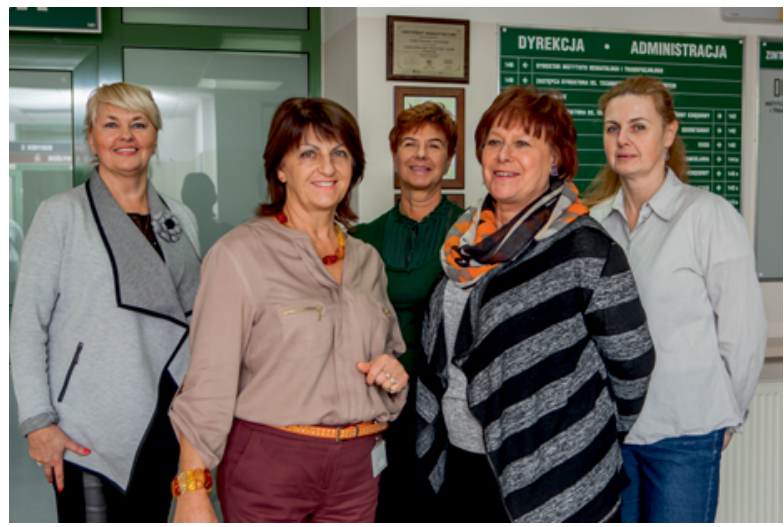

Kierownik: mgr Małgorzata Mitek

tel.: 223496 183; 223496 186; 223496199 e-mail: kadry@ihit.waw.pl

\section{Dział Zamówień Publicznych \\ i Zaopatrzenia}

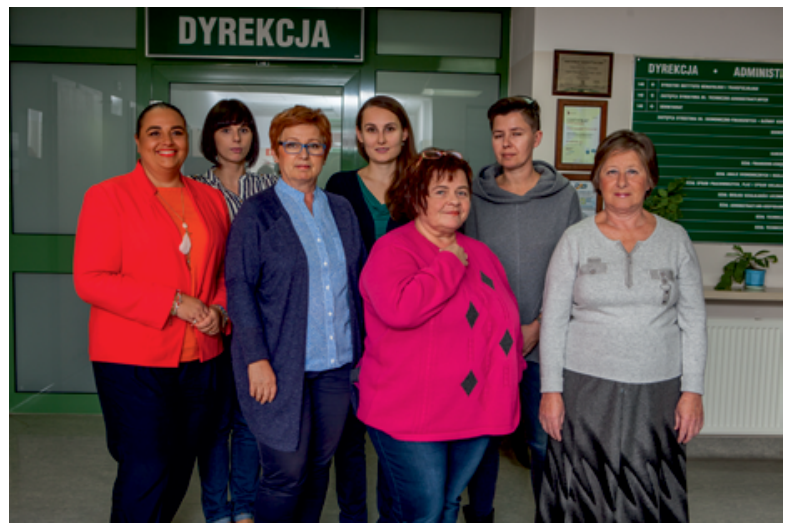

\section{Kierownik: Krystyna Sobczak}

tel.: 223496 222; 223496 225; 223496 226; 223496620

e-mail: ksobczak@ihit.waw.pl

\section{Dział Finansowo-Księgowy}

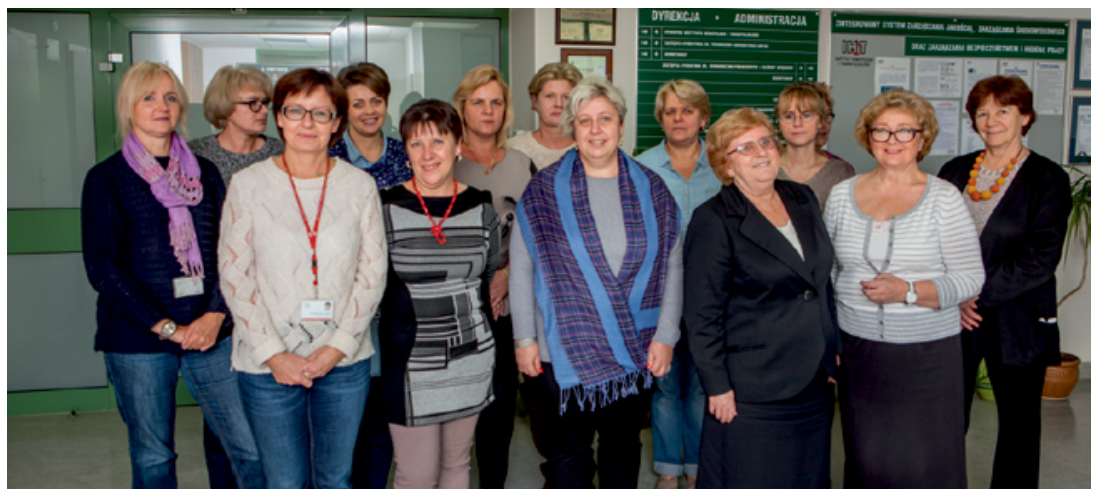

Dział Administracyjno-Techniczny

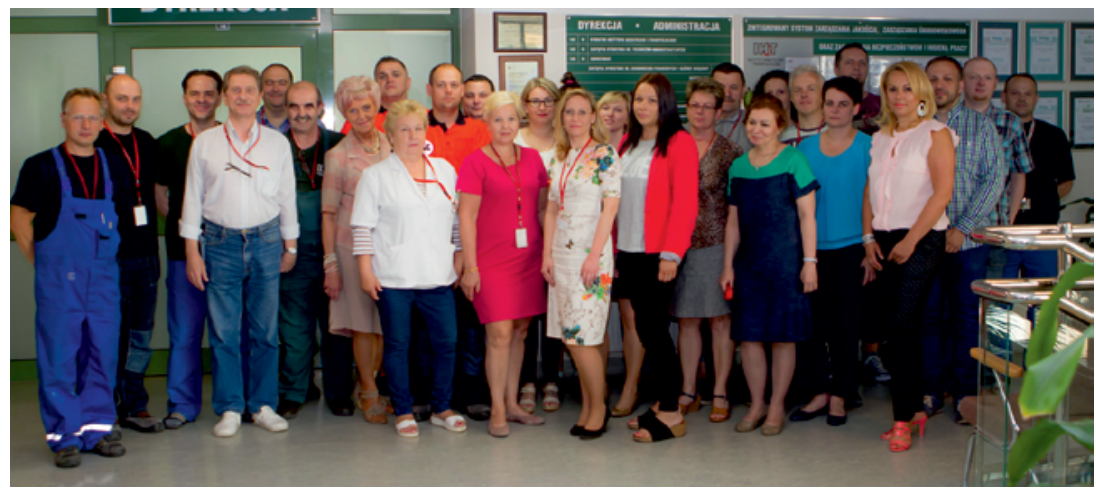

Główna Księgowa: mgr Urszula Pawlak tel. 223496103 faks: 223496189 e-mail: upawlak@ihit.waw.pl

\section{Kierownik:}

mgr Małgorzata Zajączkowska tel.: 223496 509; 601247182

\section{Kancelaria}

tel.: 223496 214; 223496215

faks: 223496213

e-mail: mzajaczkowska@ihit.waw.pl 


\section{Pełnomocnik Dyrektora ds. ochrony informacji niejawnych \\ Pełnomocnik Dyrektora ds. obronnych i zarządzania kryzysowego}

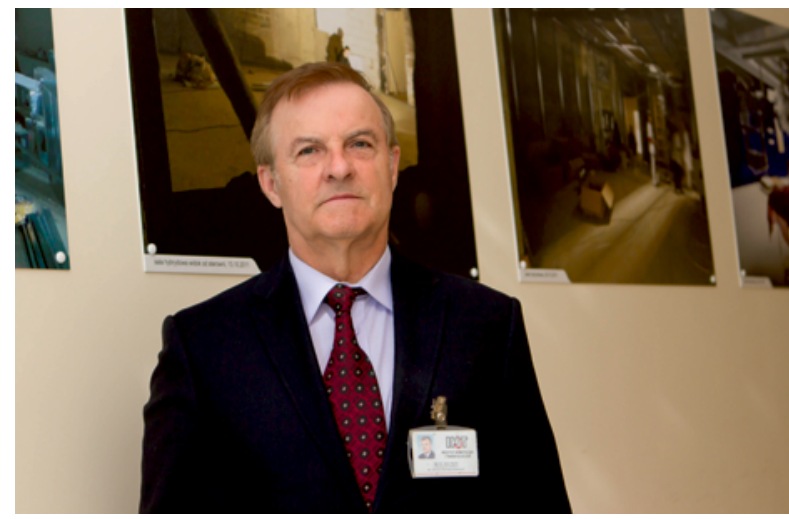

mgr Jerzy Sędzik

tel. 223496 600, w. 132

\section{Pełnomocnik Dyrektora ds. Jakości}

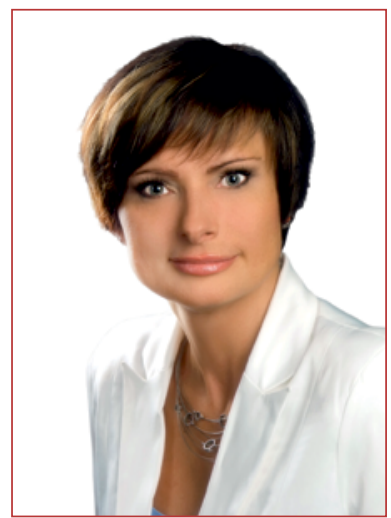

mgr Monika Białas

tel. 223496252

e-mail: mbialas@ihit.waw.pl

\section{Rzecznik prasowy \\ Pełnomocnik Dyrektora \\ ds. Praw Pacjenta \\ i Komunikacji Społecznej}

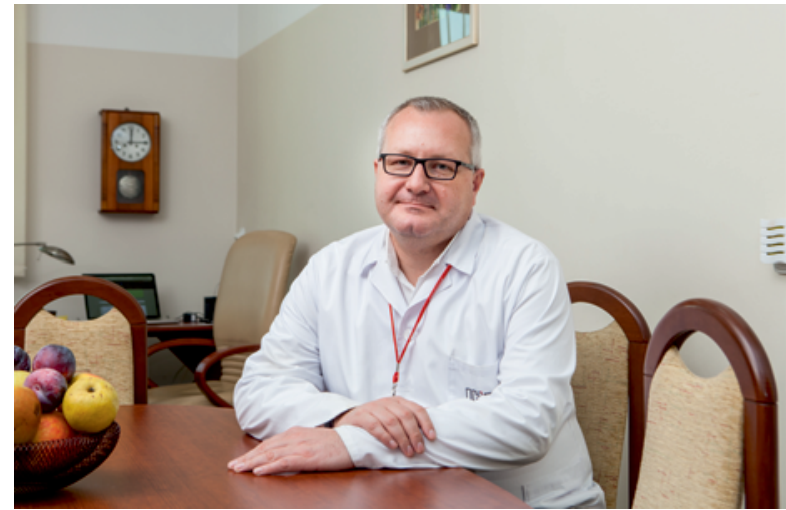

dr Witold Tomaszewski

tel. 223496360

faks 223496361

e-mail: wtomaszewski@ihit.waw.pl

Inspektor ds. BHP

Ewelina Kałun tel. 223496604

e-mail: bhp@ihit.waw.pl

Inspektor ds. ppoż.

Krzysztof Świdwa

tel. 223496604

\section{Dział Prawno-Organizacyjny}

Kierownik: mgr Zofia Kalińska

tel. 223496240

e-mail: zkalinska@ihit.waw.pl

\section{Kapelan}

ks. dr Marcin Łyżniak

tel. kom.: 603446 676; 605521566 


\section{KLINIKA HEMATOLOGII}

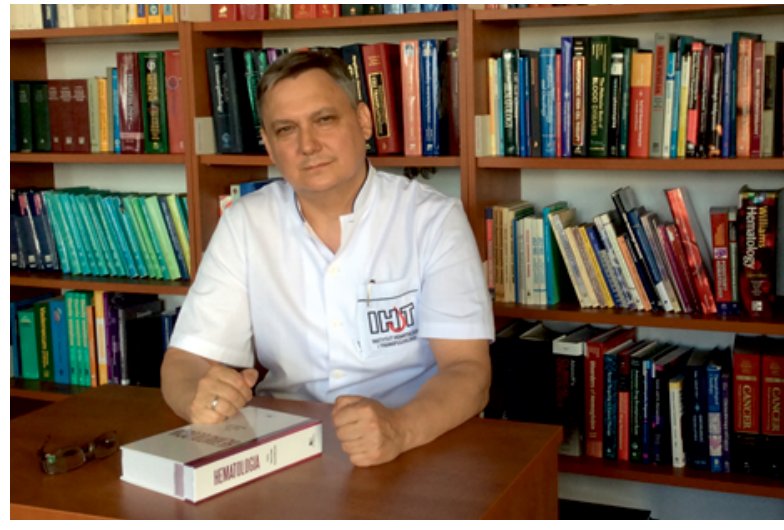

Kierownik: prof. dr hab. n. med. Krzysztof Warzocha Zastępca: prof. dr hab. n. med. Ewa Lech-Marańda Profesorowie nadzwyczajni: dr hab. n. med. Joanna Góra-Tybor, dr hab. n. med. Krzysztof Jamroziak Adiunkci: dr n. med. Ewa Mendek-Czajkowska, dr n. med. Ilona Seferyńska

Lekarze: lek. Joanna Barankiewicz, dr n. med. Bożena Katarzyna Budziszewska, lek. Monika Chełstowska, lek. Anna Ejduk, dr n. med. Aleksandra Gołos, lek. Małgorzata Jarzembowska, lek. Agnieszka Kołkowska-Leśniak, lek. Agnieszka Końska, lek. Kinga Kos-Zakrzewska, lek. Beata Kwaśniak, lek. Wioletta Makowska, dr n. med. Agata Malenda, lek. Marta Maliszewska, dr n. med. Bartosz Puła, lek. Anna Paczek,

lek. Elżbieta Patkowska, lek. Joanna Sawczuk-Chabin, lek. Urszula Walczak, lek. Joanna Wasilewska, lek. Ewa Zaczek

Pielęgniarka oddziałowa: Marzanna Milczarek Sekretariat: mgr inż. Barbara Kalinowska, Katarzyna Kozdęba

Działalność lecznicza Kliniki Hematologii obejmuje diagnostykę i leczenie oraz opiekę ambulatoryjną nad chorymi na choroby układów krwiotwórczego i chłonnego. W skład Kliniki wchodzą: Oddział Diagnostyki Hematologicznej, Oddział Chorób Układu Krwiotwórczego, Oddział Chorób Układu Chłonnego, Oddział Intensywnej Opieki Hematologicznej oraz Poradnia Hematologiczna.

Personel Oddziału Diagnostyki Hematologicznej zajmuje się diagnostyką nowotworowych i nienowotworowych chorób układów krwiotwórczego i chłonnego oraz monitorowaniem skuteczności ich leczenia. Oddział Chorób Układu Krwiotwórczego i Oddział Chorób Układu Chłonnego są ukierunkowane, odpowiednio, na leczenie chorych na nowotwory układów krwiotwórczego i chłonnego, a także zajmują

Adres: ul. Indiry Gandhi 14, 02-776 Warszawa tel. 223496334

faks 223496335

e-mail: hemsek@ihit.waw.pl

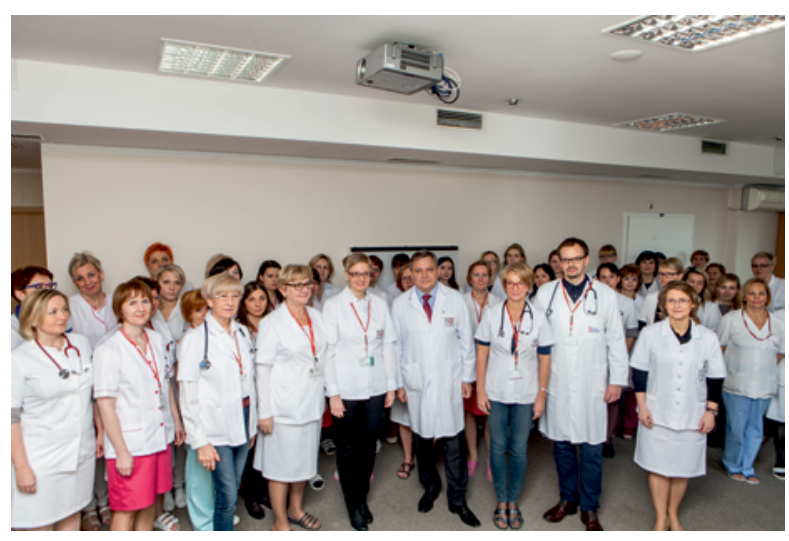

się optymalizacją i wdrażaniem nowych metod diagnostycznych i terapeutycznych. Oddział Intensywnej Opieki Hematologicznej specjalizuje się w opiece nad chorymi wymagającymi stosowania intensywnej chemioterapii i leczenia wspomagającego, w tym również terapii immunoablacyjnej $\mathrm{w}$ aplazji szpiku oraz mobilizacji krwiotwórczych komórek macierzystych do przeszczepienia. Poradnia Hematologiczna realizuje świadczenia ambulatoryjne dla pacjentów pozostających pod opieką Kliniki Hematologii.

Działalność naukowa Kliniki obejmuje optymalizację metod leczniczych i diagnostycznych w nowotworowych i nienowotworowych chorobach układów krwiotwórczego i chłonnego. Badania naukowe są realizowane przede wszystkim w oparciu o projekty badawcze inicjowane przez Polską Grupę ds. Leczenia Białaczek u Dorosłych, Polską Grupę Badawczą Chłoniaków, Polską Grupę Szpiczakową oraz $\mathrm{w}$ ramach międzynarodowych badań klinicznych. Część doświadczalna badań jest realizowana w pracowniach specjalistycznych Zakładu Hematologii Eksperymentalnej i Zakładu Diagnostyki Hematologicznej oraz w oparciu o współpracę $\mathrm{z}$ ośrodkami zewnętrznymi w kraju i za granicą.

Działalność edukacyjna Kliniki obejmuje prowadzenie wykładów na kursach dla lekarzy specjalizujących się w dziedzinie hematologii i ogólnopolskich konferencjach naukowych organizowanych pod patronatem Instytutu, tj. corocznych konferencjach Po-ASH i konferencjach czasopisma edukacyjnego „Hematologia” oraz Interaktywnych Spotkań Onkohematologicznych („Hematologia i Hemostaza”). We wspólpracy z Kliniką Hematologii i Transfuzjologii Centrum Medycznego Kształcenia Podyplomowego (CMKP) pracownicy Kliniki biorą udział w kursach dla lekarzy w ramach specjalizacji $z$ transfuzjologii klinicznej, hematologii, onkologii klinicznej i chorób wewnętrznych. Klinika posiada także akredytację umożliwiającą szkolenie lekarzy ubiegających się o specjalizację w dziedzinie hematologii. 


\section{Oddział Diagnostyki Hematologicznej}

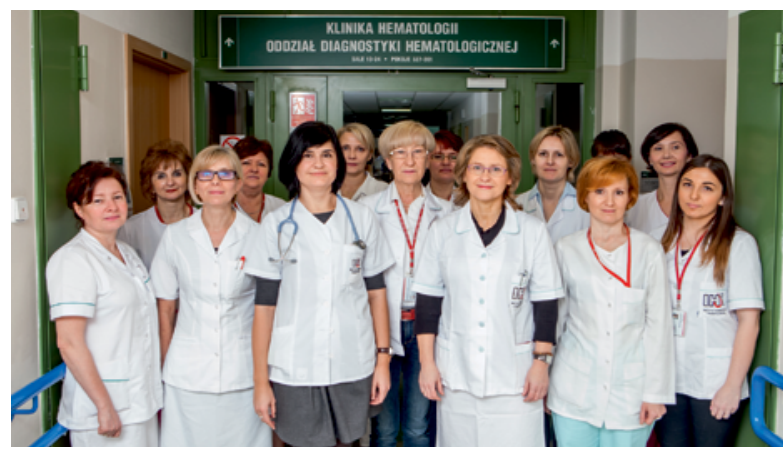

Kierownik: dr n. med. Bożena Katarzyna Budziszewska Zespół: lek. Kinga Kos-Zakrzewska, lek. Marta Maliszewska, dr n. med. Ewa Mendek-Czajkowska, dr n. med. Bartosz Puła, lek. Urszula Walczak, lek. Joanna Wasilewska Sekretariat: Agata Jarząb, Magdalena Kołaczek, mgr Agnieszka Tomaszewska tel. 223496288

e-mail: ajarzab@ihit.waw.pl

\section{Oddział Chorób Układu Krwiotwórczego}

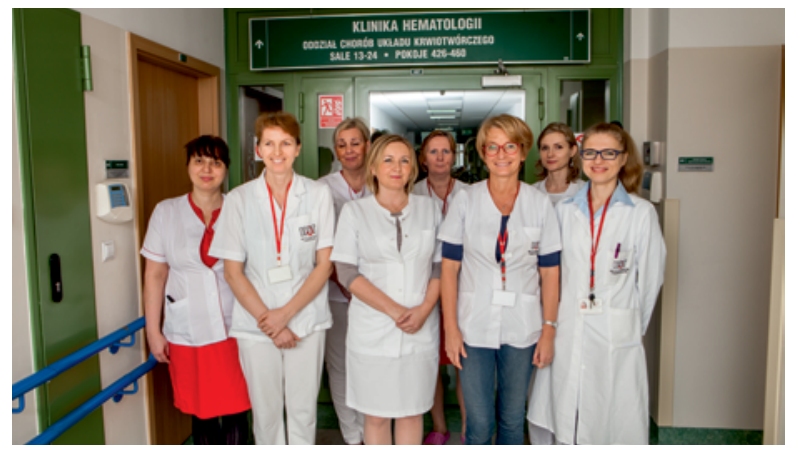

Kierownik: dr hab. n. med. Joanna Góra-Tybor, prof. nadzw.

Zespół: dr n. med. Aleksandra Gołos, lek. Wioletta Makowska, lek. Anna Paczek, lek. Elżbieta Patkowska, lek. Ewa Zaczek

Sekretariat: Lidia Michalak tel. 223496483

e-mail: Imichalak@ihit.waw.pl

\section{Oddział Chorób Układu Chłonnego}

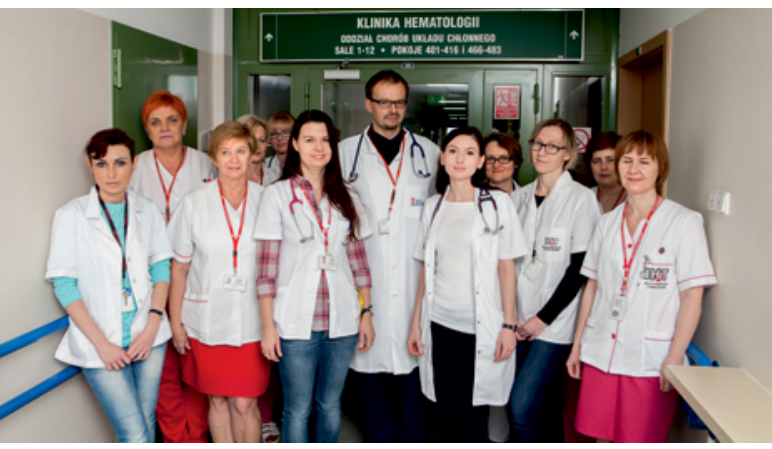

Kierownik: dr hab. n. med. Krzysztof Jamroziak, prof. nadzw.

Zespół: lek. Joanna Barankiewicz, lek. Monika Chełstowska, lek. Małgorzata Jarzembowska, lek. Agnieszka Kołkowska-Leśniak, lek. Agnieszka Końska, lek. Beata Kwaśniak, dr n. med. Agata Malenda Sekretariat: mgr Katarzyna Zielińska tel. 223496483

e-mail: kzielinska@ihit.waw.pl

\section{Oddział Intensywnej Opieki Hematologicznej}

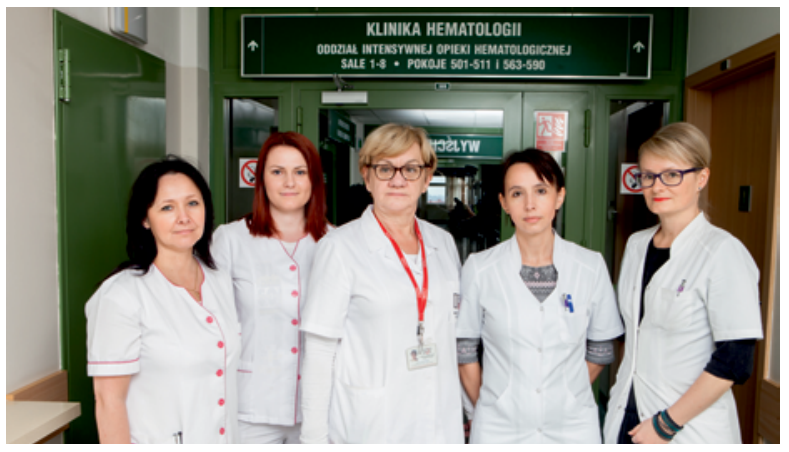

Kierownik: dr n. med. Ilona Seferyńska

Zespół: lek. Anna Ejduk, lek. Joanna Sawczuk-Chabin Sekretariat: Sylwia Kufera tel. 223496472

e-mail: skufera@ihit.waw.pl

\section{Poradnia Hematologiczna}

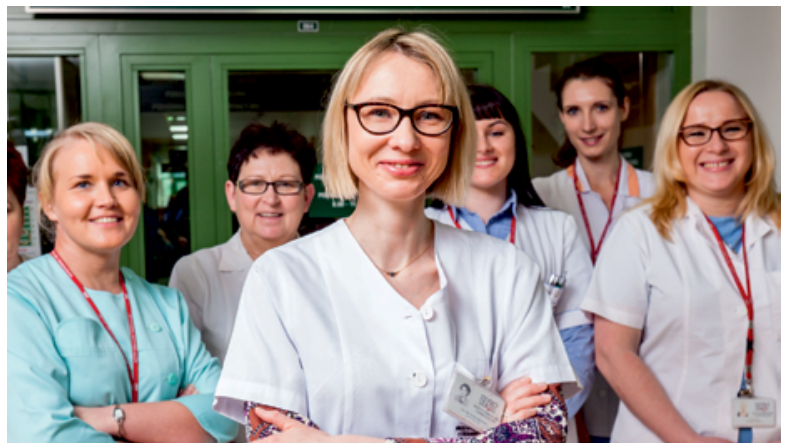

Kierownik: lek. Monika Dąbrowska tel. 223496 291; faks 223496335

e-mail: hemsek@ihit.waw.pl 


\section{KLINIKA ZABURZEŃ HEMOSTAZY I CHORÓB WEWNĘTRZNYCH}

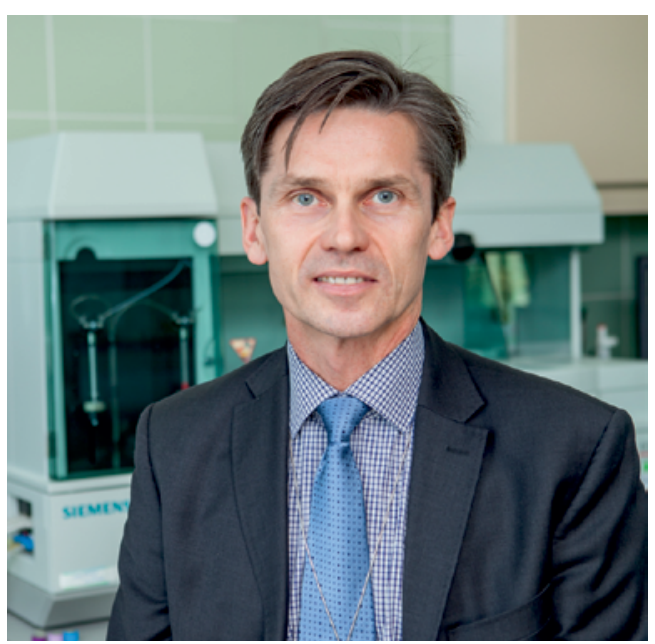

Kierownik: prof. dr hab. n. med. Jerzy Windyga Zastępca: lek. Anna Buczma

Adiunkci: dr n. med. Bernardetta Ceglarek, dr n. med. Anna Sikorska

Lekarze: dr n. med. Magdalena Górska-Kosicka, lek. Adela Gwozdowska, lek. Sławomir Jurek, lek. Joanna Sowińska, dr n. med. Robert Wasilewski Pielęgniarka oddziałowa: mgr Grażyna Grzesikiewicz-Majewska

Sekretariat: mgr Marzanna Rasińska, Aleksandra Wysoczyńska

Zespół Kliniki zajmuje się diagnostyką, leczeniem i opieką ambulatoryjną nad chorymi $z$ zaburzeniami hemostazy i chorobami wewnętrznymi, zwłaszcza $z$ towarzyszącymi chorobami układów krwiotwórczego lub chłonnego. Prowadzi także badania naukowe i szkolenia oraz udziela konsultacji $\mathrm{w}$ wyżej wymienionym zakresie.

Działalność lecznicza jest ukierunkowana przede wszystkim na potrzeby pacjentów $z$ zaburzeniami krzepnięcia, ze szczególnym uwzględnieniem procedur unikatowych w skali kraju. Klinika jest referencyjnym ośrodkiem diagnozowania i leczenia chorych na hemofilię i inne wrodzone i nabyte skazy krwotoczne w Polsce, w tym także chorych na rzadkie skazy krwotoczne (niedobór czynników VII, X, XI, XII; afibrynogenemia). Klinika koordynuje zabiegi wszczepienia endoprotez stawowych i synowektomii izotopowych u pacjentów $z$ artropatią hemofilową oraz prowadzi rehabi-

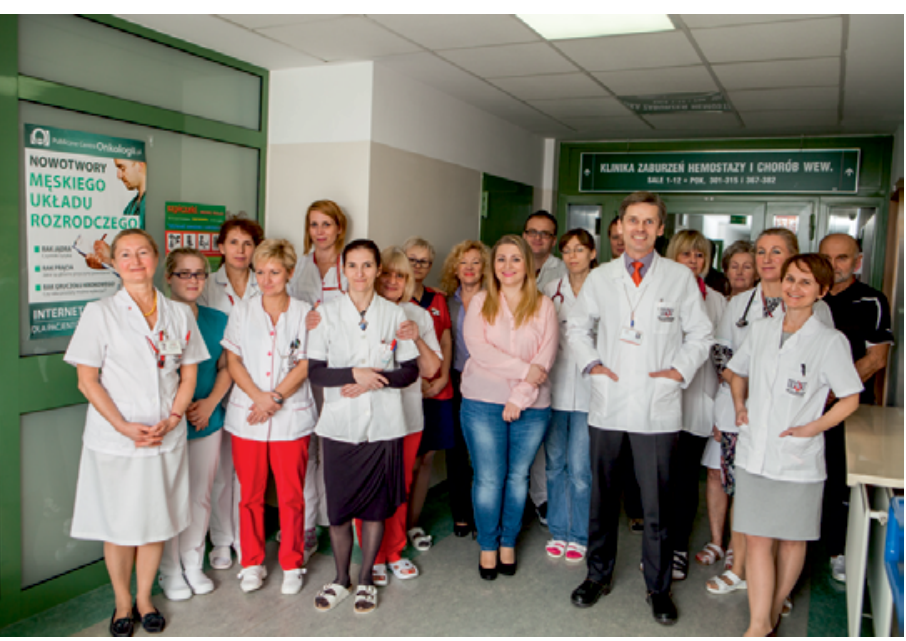

litację chorych po zabiegach operacyjnych. Ponadto prowadzi pełną diagnostykę trombofilii wrodzonej oraz zespołu antyfosfolipidowego. W Klinice przeprowadza się także pełną diagnostykę i leczenie zaostrzeń ostrej porfirii przerywanej oraz sprawuje opiekę nad chorymi z porfirią.

Działalność naukowa Kliniki koncentruje się głównie na problematyce zaburzeń hemostazy. Jest tu prowadzony centralny rejestr chorych na wrodzone skazy krwotoczne $z$ całego kraju oraz rejestr osób obarczonych trombofilią, w tym pacjentów $z$ defektami szczególnie narażającymi na wystąpienie zakrzepicy, czyli z niedoborem antytrombiny, białka C lub białka S, stanu hetero-homozygotycznego wobec mutacji typu Leiden genu czynnika V lub mutacji G20210A genu protrombiny oraz skojarzonych defektów genetycznych. Klinika współpracuje $z$ ośrodkami zagranicznymi oraz krajowymi w zakresie badań nad podłożem genetycznym wrodzonych skaz krwotocznych oraz etiologią żylnej choroby zakrzepowo-zatorowej i udaru niedokrwiennego mózgu w młodym wieku. W Klinice są prowadzone indywidualne szkolenia dla lekarzy odbywających staż specjalizacyjny z zakresu hematologii i chorób wewnętrznych.

W skład Kliniki wchodzą: Oddział Zaburzeń Hemostazy, Oddział Chorób Wewnętrznych i Geriatrii, Poradnia Kinezyterapii, Poradnia Zaburzeń Hemostazy i Poradnia dla Chorych na Porfirię i ich Rodzin.

Adres: ul. Indiry Gandhi 14, 02-776 Warszawa

tel.: 223496 158; 223496481

faks 223496159

e-mail: sekretariatkzh@ihit.waw.pl 


\section{KLINIKA TRANSPLANTACJI KOMÓREK KRWIOTWÓRCZYCH}

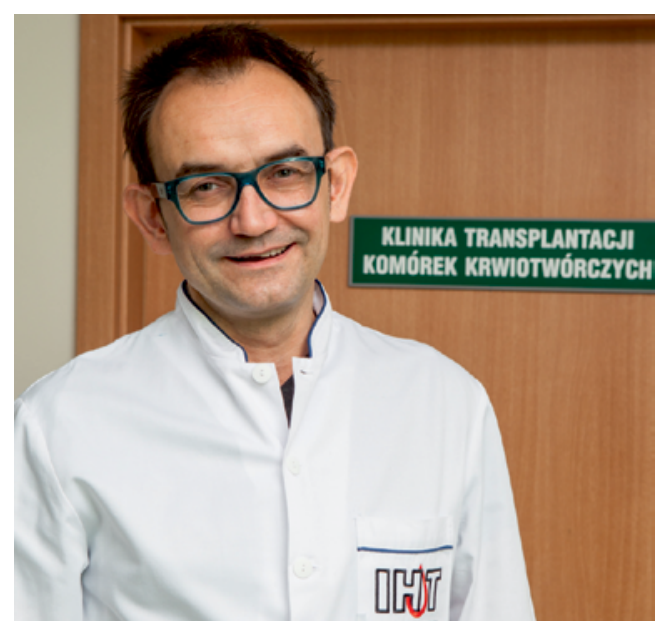

Kierownik: dr n. med. Kazimierz Hałaburda

Zastępca: dr n. med. Agnieszka Tomaszewska Adiunkt: dr n. med. Barbara Nasiłowska-Adamska Asystent: dr n. med. Andrzej Szczepiński Pielęgniarka oddziałowa: Małgorzata Kacprzak Sekretariat: Ilona Lesiak

Zespół Kliniki zajmuje się przeszczepianiem krwiotwórczych komórek macierzystych - zarówno własnych pacjenta, jak i pobranych od dawców rodzinnych oraz niespokrewnionych. Klinika dysponuje oddziałem przeszczepowym złożonym z 15 separatek wyposażonych w filtry powietrza i nadciśnienie. Opiekę nad pacjentami poddawanymi transplantacji sprawuje wykwalifikowany i doświadczony zespół lekarski i pielęgniarski. Po transplantacji opieka lekarska nad pacjentami wcześniej leczonymi w Instytucie jest kontynuowana w Poradni Potransplantacyjnej. Pacjenci kierowani na przeszczepienia $z$ innych ośrodków hematologicznych są ponownie przekazywani pod opiekę macierzystych jednostek.

Klinika ma akredytację Ministerstwa Zdrowia oraz European Society for Blood and Marrow Transplantation na pobieranie i przeszczepianie komórek krwiotwórczych. Ponadto ma także akredytację

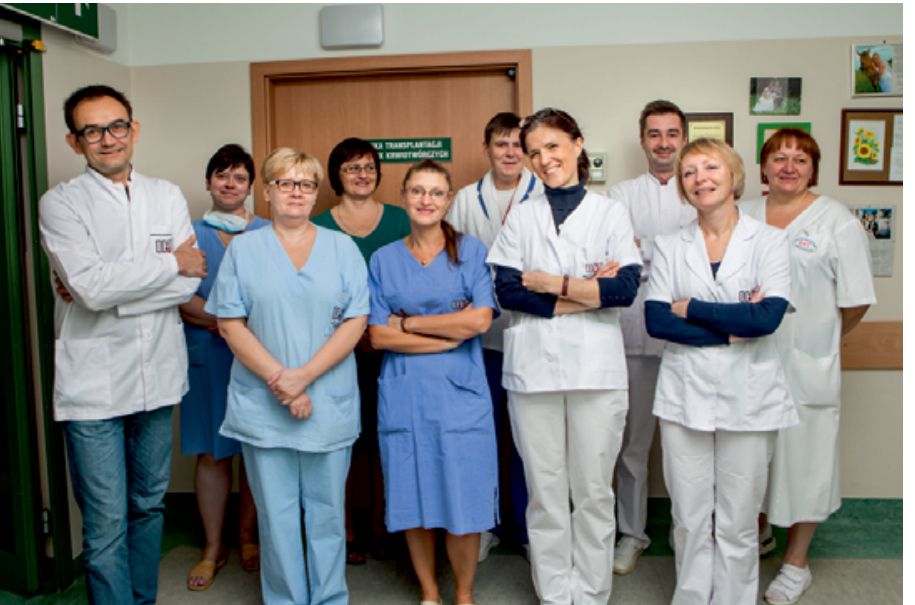

umożliwiającą szkolenie lekarzy ubiegających się o specjalizację $\mathrm{w}$ dziedzinie transplantologii klinicznej i hematologii.

Zainteresowania naukowe zespołu Kliniki dotyczą optymalizacji molekularnych metod oceny chimeryzmu hematopoetycznego w zakresie frakcji leukocytów krwi obwodowej u biorców allogenicznych komórek krwiotwórczych. Zespół Kliniki zajmuje się także oceną wpływu niezgodności w układzie ABO między dawcą i biorcą na wyniki transplantacji allogenicznych oraz analizą występowania powikłań immunohemolitycznych w tej grupie pacjentów. Działalność naukowa Kliniki dotyczy również zagadnień monitorowania wydolności układu oddechowego u chorych przed i po allotransplantacji pod kątem wczesnego rozpoznawania $z$ wiązanych $z$ przeszczepieniem powikłań, w tym zarostowego zapalenia oskrzelików. Ważnym kierunkiem badań jest ocena znaczenia genetycznych i molekularnych czynników wpływających na wyniki leczenia u chorych na ostre białaczki szpikowe.

W skład Kliniki Transplantacji Komórek Krwiotwórczych wchodzą Oddział Kliniczny i Poradnia Potransplantacyjna.

Adres: ul. Indiry Gandhi 14, 02-776 Warszawa

tel. 223496360

faks 223496361

e-mail: transplantacja@ihit.waw.pl 


\section{KLINIKA CHIRURGII OGÓLNEJ, ONKOLOGICZNEJ I METABOLICZNEJ}

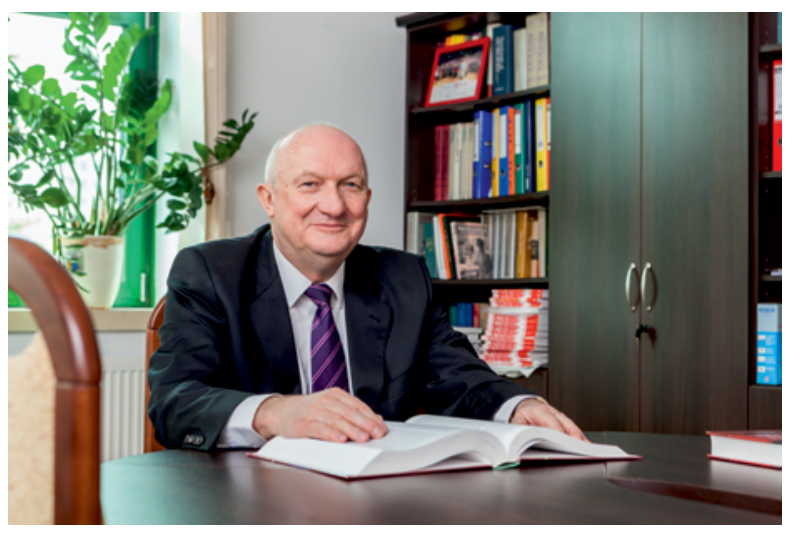

Kierownik Kliniki: prof. dr hab. n. med. Andrzej Szczepanik

Kierownik Oddziału Chirurgii Ogólnej: dr n. med. Wojciech Jaśkowiak

Kierownik Oddziału Chirurgii Onkologicznej

i Metabolicznej: dr n. med. Konrad Pielaciński

Lekarze: prof. dr hab. n. med. Marek Dedecjus, dr n. med. Sławomir Huszcza, dr n. med. Andrzej Misiak, lek. Wojciech Dąbrowski, lek. Sławomir Gajda, lek. Michał Kuryłowicz

Pielęgniarka oddziałowa: mgr Agnieszka Cholewa-Ziętek

Sekretariat: Monika Mendza, Ewa Zbiciak

Zespół Kliniki zajmuje się diagnostyką, leczeniem chirurgicznym i opieką ambulatoryjną nad chorymi z zakresu chirurgii ogólnej, zwłaszcza $z$ towarzyszącymi chorobami układów krwiotwórczego i chłonnego oraz zaburzeniami hemostazy. Ponadto prowadzi prace naukowe i szkolenia oraz udziela konsultacji w tym zakresie.

Działalność lecznicza obejmuje przede wszystkim leczenie chirurgiczne chorych na wrodzone i nabyte zaburzenia krzepnięcia krwi. W Klinice są prowadzone w pełnym zakresie operacje w przebiegu chorób onkohematologicznych, w tym splenektomia metodami klasyczną i laparoskopową. Ponadto przeprowadza się operacje $z$ zakresu chirurgii jamy brzusznej w schorzeniach nowotworowych i nienowotworowych metodami klasycznymi i laparoskopowymi.

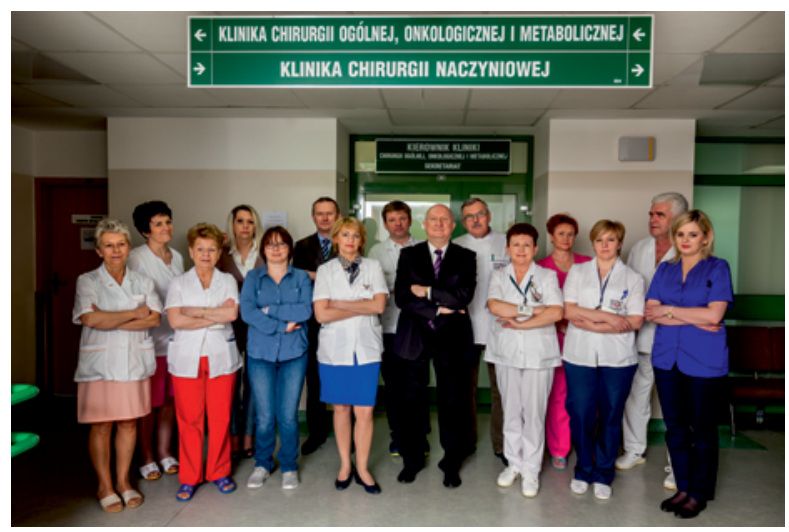

Zainteresowania naukowe zespołu Kliniki koncentrują się na zagadnieniach $z$ zakresu chirurgii ogólnej, onkologicznej i metabolicznej, chirurgicznego leczenia chorych $z$ wrodzonymi zaburzeniami hemostazy, leczenia nadciśnienia wrotnego oraz zapobiegania przewlekłej chorobie zakrzepowo-zatorowej i jej leczenia. Zespół Kliniki prowadzi badania naukowe dotyczące diagnostyki i leczenia przewlekłych krwawień $z$ przewodu pokarmowego $u$ chorych na hemofilie i chorobę von Willebranda oraz nad zastosowaniem rekombinowanego aktywowanego czynnika VII w zagrażających życiu krwawieniach u chorych na hemofilię $z$ wysokim mianem inhibitora czynnika VIII. Realizowane są także prace nad oceną przydatności splenektomii wykonywanej w różnych schorzeniach hematologicznych i niehematologicznych, a zwłaszcza nad optymalizacją techniki laparoskopowej wycięcia tego narządu. Zespół Kliniki prowadzi również badania skuteczności żelu płytkowego w leczeniu niegojących się owrzodzeń troficznych różnej lokalizacji. Klinika współpracuje $z$ wieloma ośrodkami w Polsce w cyklu szkoleń $z$ zakresu zaburzeń hemostazy w chirurgii i anestezjologii.

W skład Kliniki wchodzą: Oddział Chirurgii Ogólnej, Oddział Chirurgii Onkologicznej i Metabolicznej, Pracownia Endoskopowa oraz Poradnia Chirurgiczna.

Adres: ul. Indiry Gandhi 14, 02-776 Warszawa

tel.: 223496 271; 223496470

faks 223496272

e-mail: chirurg@ihit.waw.pl 


\section{KLINIKA CHIRURGII NACZYNIOWEJ}

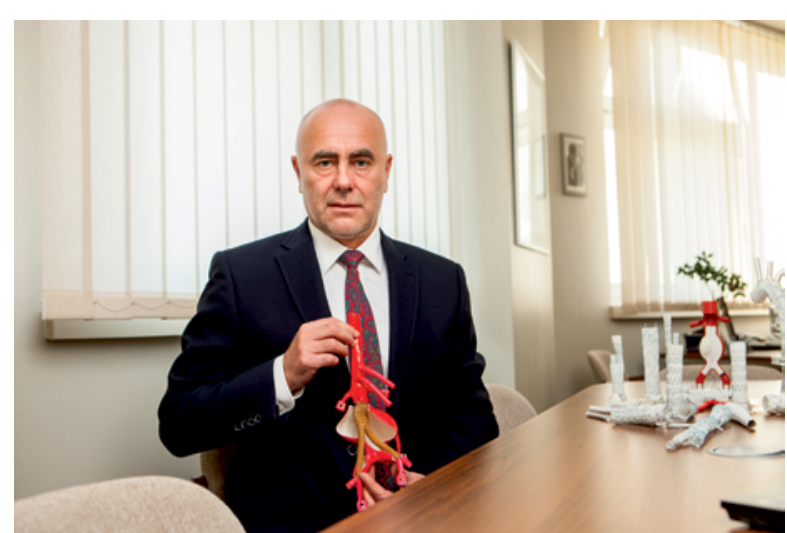

Kierownik: dr hab. n. med. Piotr Szopiński, prof. nadzw.

Zastępca Kierownika Kliniki: dr n. med. Jacek Michalak Kierownik Pracowni Radiologii Zabiegowej:

dr n. med. Jarosław Iwanowski

Adiunkt: dr n. med. Eliza Pleban

Asystent: dr n. med. Adam Wiszniewski

Lekarze: dr n. med. Marcin Janas, lek. Radosław Bilski, lek. Marcin Sitarz, lek. Tomasz Dobrowolski, lek. Maciej Stryga

Pielęgniarka oddziałowa: mgr Ida Kacprzak Sekretariat: mgr Joanna Kurzyńska, mgr Wiktoria Kowalska

Klinika Chirurgii Naczyniowej rozpoczęła swoją działalność w 2009 roku. Zespół Kliniki zajmuje się diagnostyką, leczeniem i opieką ambulatoryjną nad chorymi w dziedzinie chirurgii naczyniowej, a także udziela konsultacji w tym zakresie. W Klinice przeprowadza się wszystkie zabiegi z zakresu chirurgii naczyń metodami klasycznymi oraz najnowocześniejszymi technikami wewnątrznaczyniowymi - około 1200 operacji rocznie, w tym około 80 implantacji stent-graftów aortalnych. W marcu 2012 roku otwarto jedną z najnowocześniejszych sal hybrydowych w Europie, co pozwoliło na rozszerzenie zakresu przeprowadzanych operacji o zabiegi hybrydowe na aorcie piersiowej i brzusznej łączące techniki chirurgiczne $z$ implantacją stentów i stent-graftów oraz wszczepianie stentów do układu żylnego.
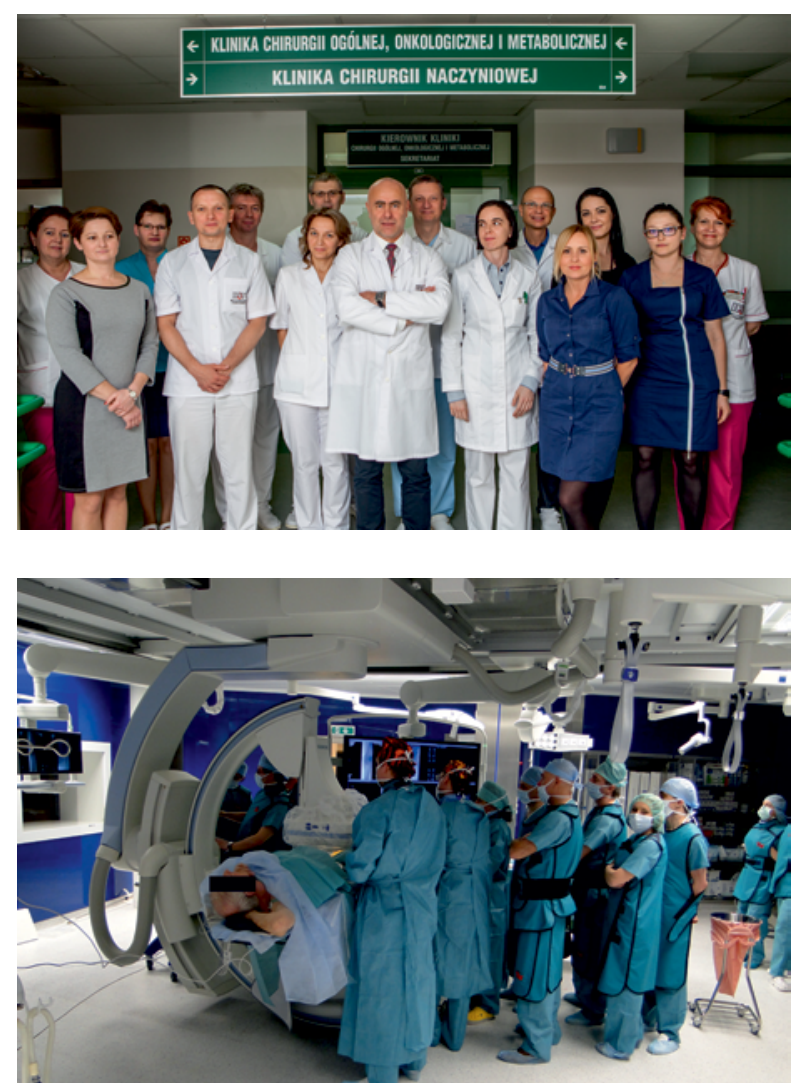

Aktywność naukowa Kliniki obejmuje ocenę wyników leczenia chorych $z$ tętniakami aorty piersiowej i brzusznej zastosowaniem stent-graftów, stosowania protez biologicznych u chorych $z$ zakażeniem lub obciążonych wysokim ryzykiem zakażenia pomostu naczyniowego oraz ocenę odległych wyników angioplastyki tętnic podudzia przy użyciu cewników balonowych pokrytych paklitakselem u chorych na cukrzycę.

Zespół Kliniki prowadzi działalność naukowo-dydaktyczną, współpracując $z$ innymi placówkami naukowo-badawczymi oraz ośrodkami klinicznymi w Polsce i za granicą. Organizowane są tu szkolenia indywidualne i cykliczne warsztaty $z$ zakresu chirurgii naczyniowej dla lekarzy z Polski i zagranicy oraz pielęgniarek.

W skład Kliniki wchodzą: Oddział Chirurgii Naczyniowej, Pracownia Radiologii Zabiegowej oraz Poradnia Chirurgii Naczyniowej.

Adres: ul. Indiry Gandhi 14, 02-776 Warszawa

tel. 223496479

faks 223496110

e-mail: vascular@ihit.waw.pl 


\section{ODDZIAŁ ANESTEZJOLOGII I INTENSYWNEJ TERAPII}

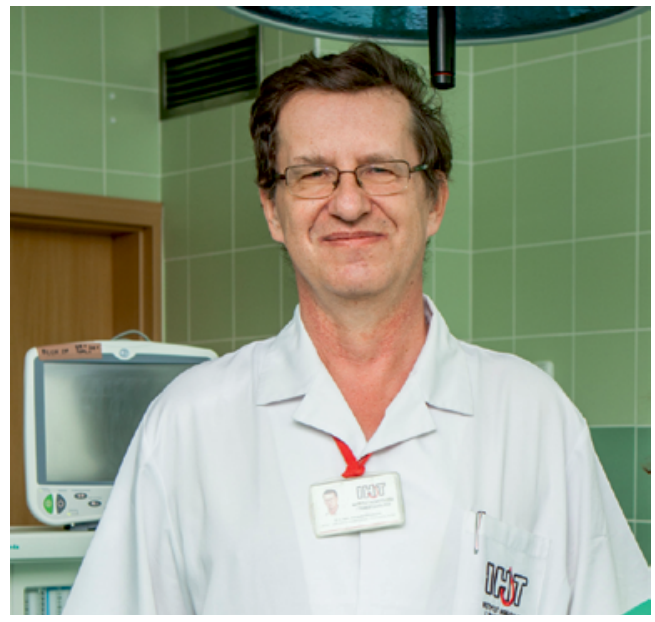

Kierownik: dr n. med. Krzysztof Przybylski Zastępca: lek. Alina Ostas

Lekarze: lek. Adam Grabowski, lek. Krzysztof Juszko, lek. Katarzyna Krysztopik, lek. Krzysztof Panek, lek. Monika Pytlewska, dr n. med. Krzysztof Rusiniak Pielęgniarka oddziałowa: mgr Barbara Wójcik Sekretariat: Eleonora Marszał

Oddział Anestezjologii i Oddział Intensywnej Terapii prowadzą opiekę anestezjologiczną nad chorymi leczonymi chirurgicznie oraz diagnostykę i leczenie wszystkich chorych Instytutu pozostających w stanie bezpośredniego zagrożenia życia lub wymagających monitorowania i podtrzymywania podstawowych funkcji życiowych. Sprawuje także stały dyżur reanimacyjny i konsultacyjny w Instytucie. Na Oddziale są wykonywane znieczulenia $\mathrm{u}$ chorych poddawanych zabiegom operacyjnym, $\mathrm{w}$ tym znieczulenia u chorych $\mathrm{z}$ zaburzeniami krzep-

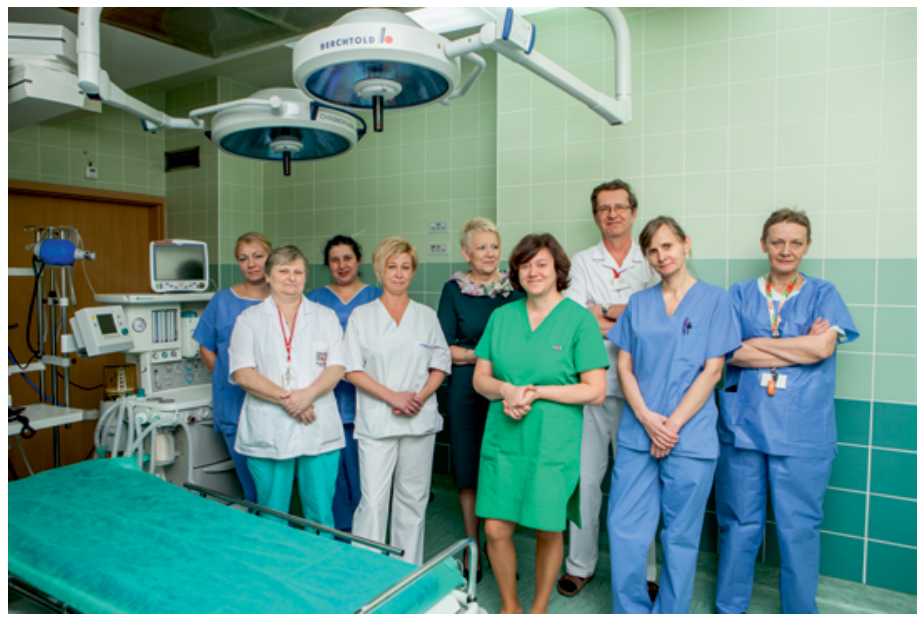

nięcia krwi do rozległych zabiegów operacyjnych i znieczulenia chorych $z$ grupy wysokiego ryzyka do skomplikowanych zabiegów w chirurgii naczyniowej, w tym zabiegów wewnątrznaczyniowych. Sprawowana jest również opieka pooperacyjna nad chorymi bezpośrednio po zabiegach. Zespół Oddziału zajmuje się także zapewnieniem dostępów dożylnych u chorych poddawanych chemioterapii, przeszczepieniu krwiotwórczych komórek macierzystych i innym procedurom wymagającym założenia specjalistycznych kaniul dożylnych. Na Oddziale stworzono warunki do prowadzenia terapii nerkozastępczej i plazmaferez oraz możliwości stymulacji zewnętrznej i endokawitarnej serca. Zespół Oddziału zajmuje się również leczeniem bólu, zwłaszcza towarzyszącego chorobom nowotworowym.

W skład Oddziału wchodzą Oddział Anestezjologii i Oddział Intensywnej Terapii.

Adres: ul. Indiry Gandhi 14, 02-776 Warszawa tel.: 223496 474; 223496409

faks 223496462

e-mail: emarszal@ihit.waw.pl 


\section{BLOK OPERACYJNY}

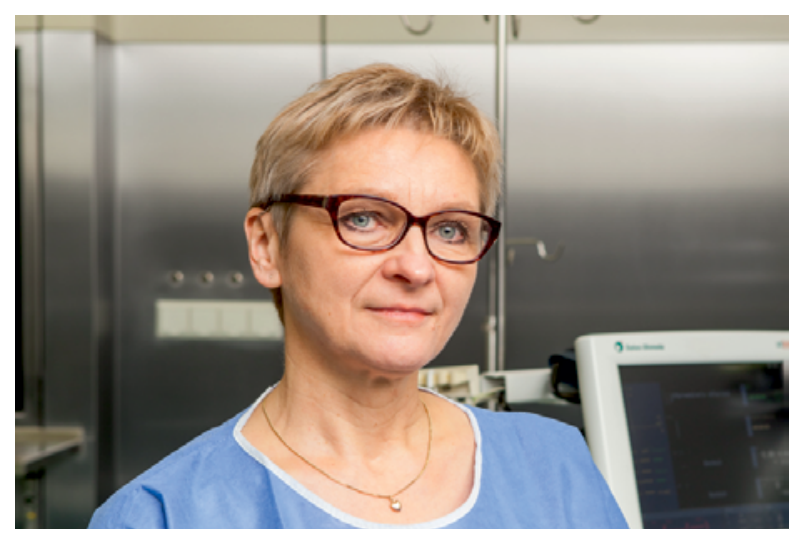

Kierownik: lek. Alina Ostas

Pielęgniarka oddziałowa: mgr Elżbieta Sosnowska

Blok Operacyjny obejmuje swoim zakresem organizację leczenia chirurgicznego w Instytucie. Dysponuje trzema klimatyzowanymi salami operacyjnymi wyposażonymi $\mathrm{w}$ filtry $\mathrm{z}$ laminarnym przepływem powietrza oraz salą wybudzeń. Sale operacyjne są wykorzystywane przez Klinikę Chirurgii Ogólnej, Onkologicznej i Metabolicznej oraz Klinikę Chirurgii Naczyniowej. Sala hybrydowa, otwarta w 2012 roku, umożliwiła rozszerzenie zakresu przeprowadzanych operacji o zabiegi łączące tech-

Adres: ul. Indiry Gandhi 14, 02-776 Warszawa tel. 223496426

e-mail: emarszal@ihit.waw.pl
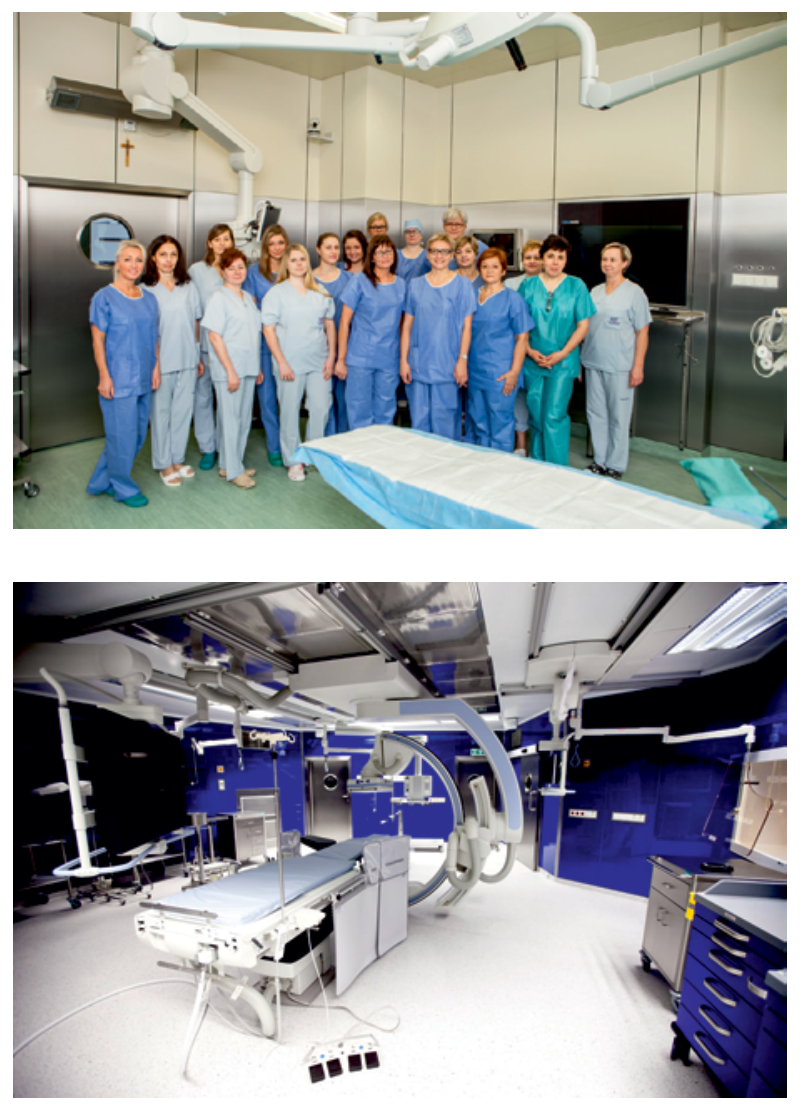

niki chirurgiczne zewnątrz- i wewnątrznaczyniowe $z$ implantacją stentów i stent-graftów, w tym do aorty piersiowej i brzusznej oraz do układu żylnego.

\section{IZBA PRZYJĘĆ}

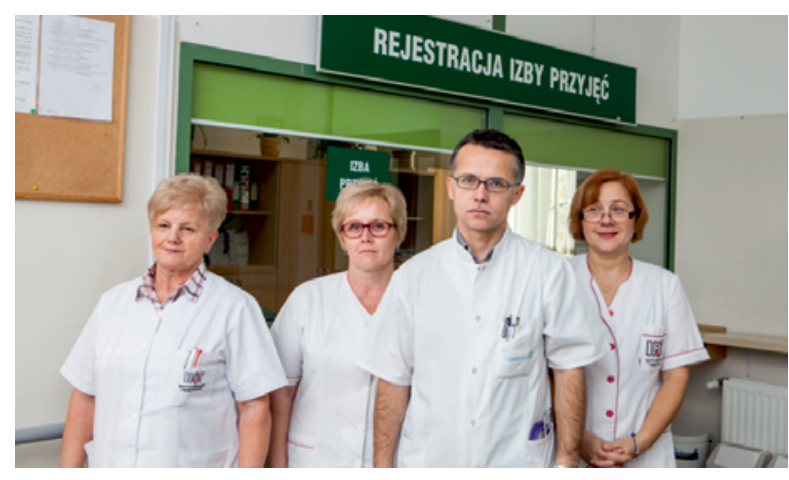

Kierownik: lek. Tomasz Szpila

Lekarz: dr n. med. Bernadetta Ceglarek

Pielęgniarka oddziałowa: mgr Iwona Redel

Zespół pielęgniarski: Magdalena Janisz, Maria Piotrowska, Elżbieta Mirek, Grażyna Wojciechowska, Dorota Zembek, Stanisława Sas, Beata Wiśniewska

Salowe: Barbara Chmielewska, Bożena Nowak Adres: ul. Indiry Gandhi 14, 02-776 Warszawa tel.: 223496 146; 223496147

e-mail: izba@ihit.waw.pl

\section{APTEKA}

Kierownik: mgr Urszula Szustkiewicz

Adres: ul. Chocimska 5, 00-791 Warszawa

tel. 223496612

faks 223496613

e-mail: apteka@ihit.waw.pl 


\section{ODDZIAŁ LECZENIA DZIENNEGO}

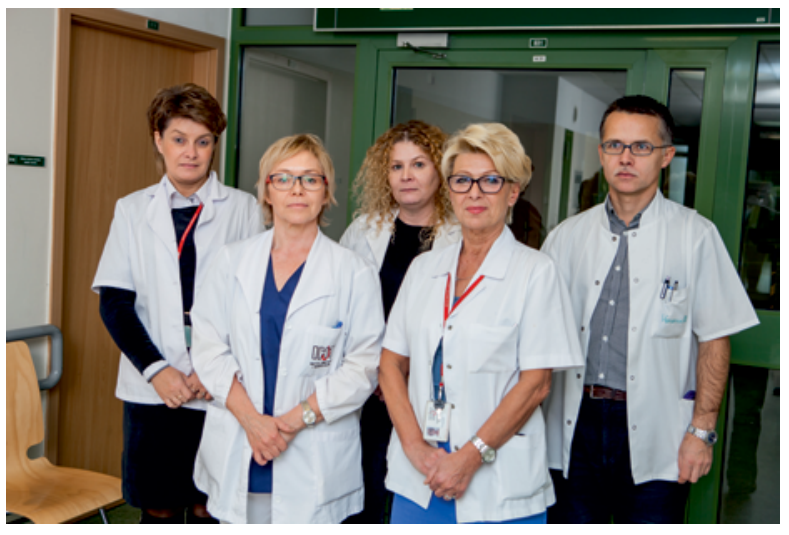

Kierownik: lek. Joanna Włodarska

Lekarz: lek. Tomasz Szpila

Sekretariat: Małgorzata Olejniczak

Kierownik: lek. Joanna Włodarska

Lekarz: lek. Katarzyna Michalak

Sekretariat: Martyna Piątkowska, Ewelina Głowacka
Na Oddziale Leczenia Dziennego w siedzibie przy ul. Indiry Gandhi 14 oraz przy ul. Chocimskiej 5 jest prowadzone leczenie $\mathrm{w}$ ramach procedur jednodniowych. Pacjenci są przyjmowani zarówno z Klinik Instytutu Hematologii i Transfuzjologii, jak i Poradni Hematologicznej w celu podania chemioterapii. Jednocześnie na Oddziale prowadzi się leczenie wspomagające biofosfanianami oraz substytucję gammaglobulin. Ponadto wykonywane są krwioupusty lecznicze oraz dożylna suplementacja żelaza.

Adres: ul. Indiry Gandhi 14, 02-776 Warszawa tel. 223496150

faks 223496492

e-mail: old@ihit.waw.pl

Adres: Chocimska 5, 00-957 Warszawa

tel. 223496628

faks 223496619

e-mail: old@ihit.waw.pl

\section{LEKARZ EPIDEMIOLOG PIELĘGNIARKA EPIDEMIOLOGICZNA}

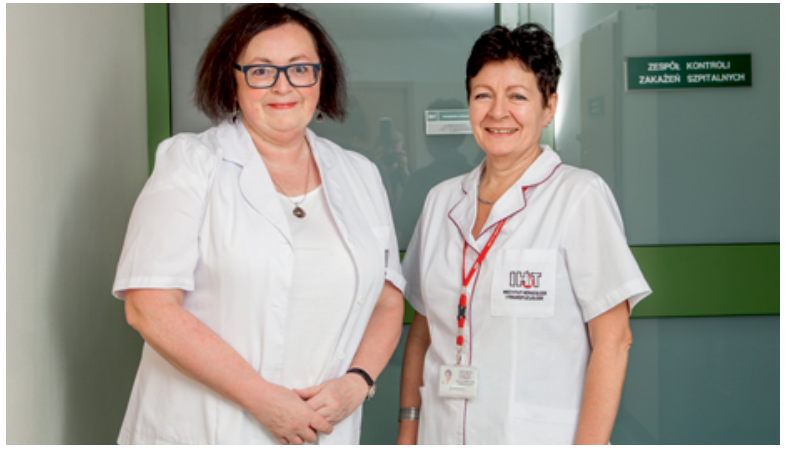

Lekarz epidemiolog: dr hab. n. med. Marta Wróblewska Pielęgniarka epidemiologiczna: mgr Małgorzata Giemza

Adres: ul. Indiry Gandhi 14, 02-776 Warszawa tel./faks 223496245

e-mail: mgiemza@ihit.waw.pl

\section{PSYCHOLOG KLINICZNY}

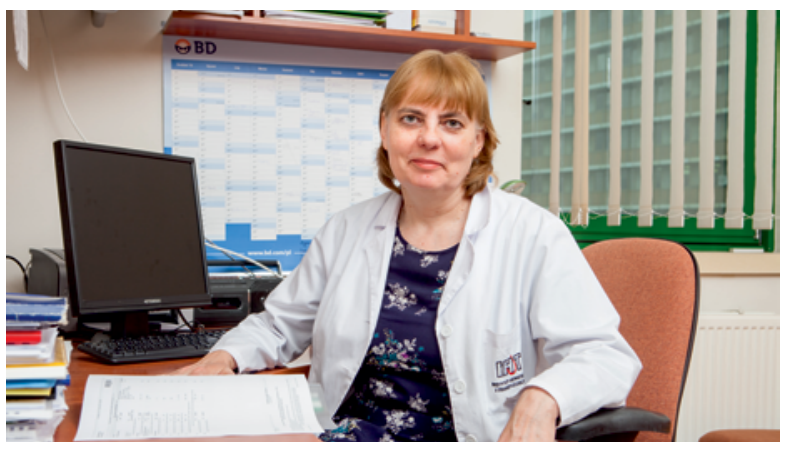

mgr Małgorzata Piątek

Adres: ul. Indiry Gandhi 14, 02-776 Warszawa tel. 223496472

e-mail: mpiatek@ihit.waw.pl

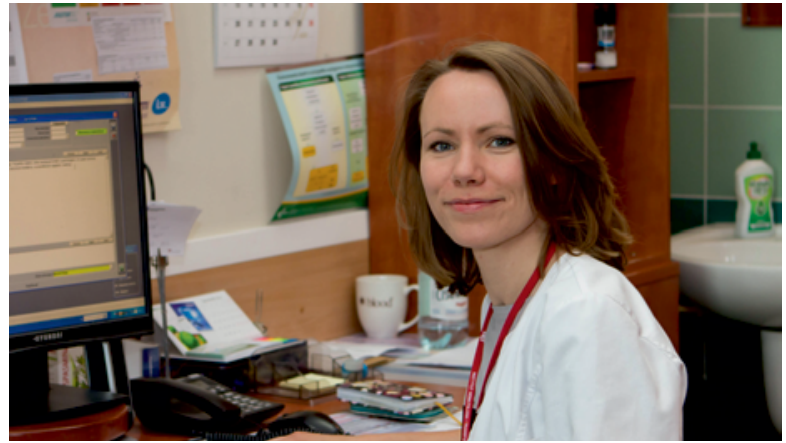

mgr Kinga Bystrek

Adres: ul. Indiry Gandhi 14, 02-776 Warszawa tel. 223496333 


\section{PRZYCHODNIA SPECJALISTYCZNA}

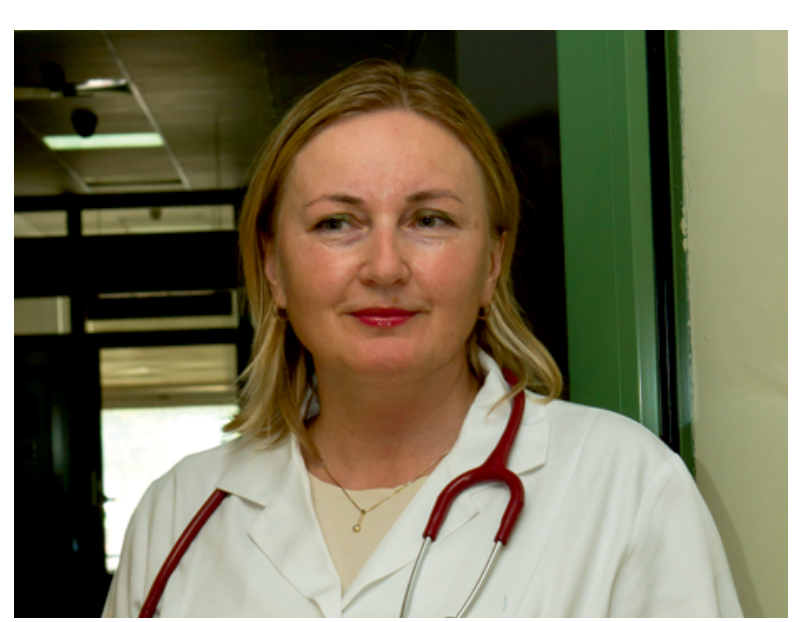

Kierownik przychodni: dr n. med. Elżbieta Mądro Lekarze: dr n. med. Izabela Kopeć, lek. Agnieszka Łuczak, dr n. med. Ewa Mendek-Czajkowska, lek. Tomasz Russjan, lek. Ewa Stefańska-Windyga, lek. Hanna Wróblewska-Kozak

Konsultant: prof. dr hab. n. med. Stanisław Maj Kierownik rejestracji: Dagmara Malczyk

Przychodnia Specjalistyczna udziela ambulatoryjnych porad i konsultacji lekarskich w zakresie chorób układów krwiotwórczego i chłonnego, w tym prowadzi diagnostykę $\mathrm{w}$ ramach karty diagnostyki i leczenia onkologicznego. Przychodnia prowadzi diagnostykę i leczenie zaburzeń krzepnięcia, zajmuje się również diagnostyką i leczeniem kobiet w ciąży $z$ chorobami hematologicznymi, konfliktami serologicznymi oraz diagnostyką hematologiczną nawykowych niepowodzeń rozrodu. Do zadań Przychodni należą również kwalifikacja i kierowanie chorych na leczenie w Klinice Hematologii, na Oddziale Leczenia Dziennego i w Klinice Zaburzeń Hemostazy i Chorób Wewnętrznych lub pod opiekę jednostek podstawowej opieki zdrowotnej. Zespół Przychodni jest również odpowiedzialny za przeprowadzanie badań wstępnych, okresowych i kontrolnych u pracowników Instytutu.

W skład Przychodni Specjalistycznej wchodzą: Poradnia Chorób Krwi, Poradnia Zaburzeń
Krzepnięcia, Poradnia Hematologiczna dla Kobiet w Ciąży, Poradnia dla Chorych na Wrodzone Niedokrwistości oraz Poradnia Medycyny Pracy.

\section{Poradnia Chorób Krwi}

Kierownik: dr n. med. Elżbieta Mądro

Lekarze: lek. Agnieszka Łuczak, lek. Tomasz Russjan Adres: ul. Chocimska 5, 00-791 Warszawa, budynek A, I piętro

tel.: 223496 609; 223496653

faks 223496619

\section{Poradnia Hematologiczna dla Kobiet w Ciąży}

Kierownik: dr n. med. Izabela Kopeć

Adres: ul. Chocimska 5, 00-791 Warszawa, budynek A, I piętro

tel.: 223496 609; 223496653

faks 223496619

\section{Poradnia Zaburzeń Krzepnięcia}

Kierownik: lek. Ewa Stefańska-Windyga

Adres: ul. Indiry Gandhi 14, 02-776 Warszawa

tel.: 223496 100; 223496132

\section{Poradnia dla Chorych na Wrodzone Niedokrwistości}

Kierownik: dr n. med. Ewa Mendek-Czajkowska Adres: ul. Indiry Gandhi 14, 02-776 Warszawa, blok A, parter (Przychodnia Specjalistyczna)

tel. 223496129

faks 223496459

\section{Poradnia Medycyny Pracy}

Lekarz: lek. Hanna Wróblewska-Kozak

Adres: ul. Indiry Gandhi 14, 02-776 Warszawa

tel. 223496 00, wew.: 129, 131, 132, 297

faks 223496459

Adres: ul. Chocimska 5, 00-791 Warszawa

tel.: $223496609 ; 223496653$

faks 223496619

Adres: ul. Indiry Gandhi 14, 02-776 Warszawa

tel. 223496 00, wew.: 129, 131, 132, 297

faks 223496459

e-mail: przychodnia@ihit.waw.pl 


\section{ZAKŁAD TRANSFUZJOLOGII}

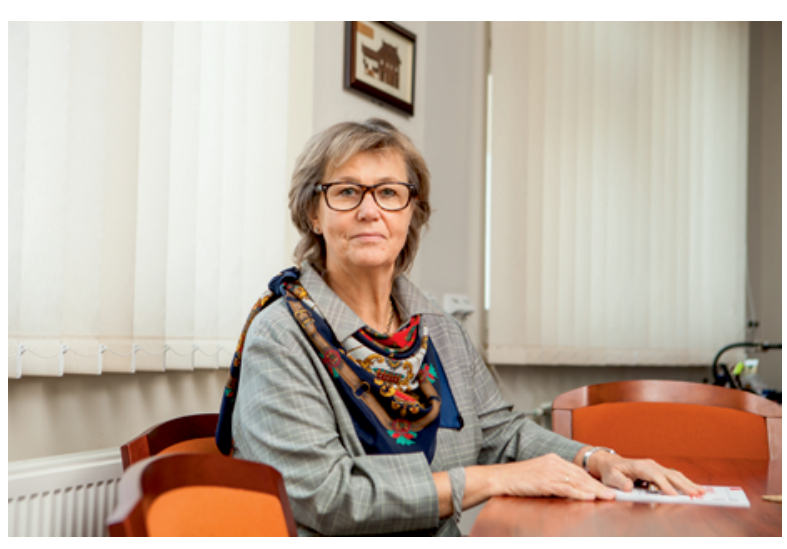

Kierownik: prof. dr hab. n. med. Magdalena Łętowska Zastępca: dr n. farm. Elżbieta Lachert

Profesorowie: prof. dr hab. n. med. Ryszard Pogłód

Adiunkci: dr n. farm. Jolanta Antoniewicz-Papis, dr n. farm. Elżbieta Lachert, dr n. med. Aleksandra Rosiek Asystent: dr n. farm. Jolanta Kubis

Lekarze: lek. Lech Rzymkiewicz, lek. Monika Grzegorek Pielęgniarki: mgr Beata Wiśniewska, mgr Ewa Pietrowiak, mgr Milena Prusaczyk, Iwona Dziarnowska, Bożena Knyt, Monika Matusz, Ewa Szczepańska, Marzena Wójcik, Elżbieta Zawirska

Diagności laboratoryjni: mgr Anna Kuziak, mgr Ewa Mik, mgr Karolina Pieńko, mgr Ewa Potocka, mgr Anna Tomaszewska

Młodsi asystenci: mgr Artur Ejduk, mgr Tomasz Jankowski, mgr Marta Gawryś, mgr Agata Płodzich Technicy: st. tech. Małgorzata Pawlik, st. tech. Bożena Wasilewska, st. tech. Elżbieta Wiśniakowska Pomoce laboratoryjne: Elżbieta Kępka, Marzena Kłokocka Sekretarki: mgr Karolina Milewska, Elżbieta Kowalczyk, Żaneta Mioduszewska

Filolog angielski: mgr Krystyna Dudziak

Starsi referenci: mgr Aleksandra Czajkowska, mgr Martyna Romańska-Płużańska

Rejestratorzy medyczni: Elżbieta Frankowska, Zygmunt Karasiński

Starsi inspektorzy ds. informatyki: inż. Krzysztof Sutkowski, Paweł Kłobukowski

Zakład prowadzi działalność naukową i usługową w dziedzinie transfuzjologii i mikrobiologii, a także realizuje szkolenia i udziela konsultacji w tym zakresie. Zespół Zakładu zajmuje się również prowadzeniem Krajowego Rejestru Dawców Krwi, Ośrodka Dawców Szpiku, Banku Komórek Macierzystych i Banku Krwi oraz prowadzi nadzór nad bezpieczeństwem leczenia

Adres: ul. Indiry Gandhi 14, 02-776 Warszawa

tel. 223496371

faks 223496372

e-mail: bloodorg@ihit.waw.pl

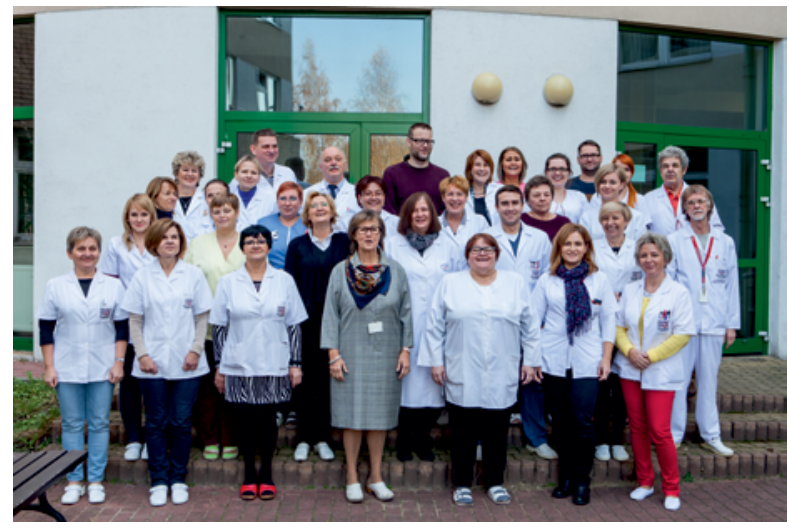

składnikami krwi i produktami krwiopochodnymi w Instytucie.

Zakład Transfuzjologii prowadzi także działalność wynikającą z zadań ustawy o publicznej służbie krwi. Pełni nadzór merytoryczny nad jednostkami organizacyjnymi publicznej służby krwi, publikuje medyczne zasady pobierania krwi, oddzielania jej składników i ich wydawania, a także przeprowadza kontrole w Centrach Krwiodawstwa i Krwiolecznictwa (CKiK). Zakład sprawuje kontrolę jakości składników krwi wytwarzanych w CKiK oraz bierze udział $\mathrm{w}$ pracach związanych $\mathrm{z}$ rejestracją i zwalnianiem serii produktów krwiopochodnych (osoczopochodne koncentraty czynników krzepnięcia i immunoglobulina anty-D). Ponadto w ramach współpracy z Ministerstwem Zdrowia i Narodowym Centrum Krwi (NCK) bierze udział w pracach legislacyjnych z zakresu krwiodawstwa i krwiolecznictwa. Zakład uczestniczy także w realizacji projektów Wspólnoty Europejskiej z zakresu krwiodawstwa i krwiolecznictwa.

W Zakładzie Transfuzjologii działają, zgodnie z ustawą o przeszczepianiu tkanek i narządów, ośrodek pobierający, ośrodek dawców szpiku i laboratorium wykonujące preparatykę krwiotwórczych komórek macierzystych (HSC, hematopoietic stem cells). W związku $z$ tym działalność usługowa Zakładu obejmuje: pobieranie HSC - zarówno ze szpiku, jak i krwi obwodowej - ich przygotowywanie do przeszczepiania oraz preparatykę krwi pępowinowej. Zakład prowadzi także Ośrodek Dawców Szpiku we współpracy $z$ innymi zakładami Instytutu. Poza tym przygotowuje „sztuczne łzy” $z$ autologicznej surowicy dla pacjentów $z$ zespołem suchego oka, między innymi w przebiegu choroby przeszczep przeciw gospodarzowi (GvHD, graft versus host disease) oraz przygotowuje podstawowe składniki autologicznego kleju fibrynowego i żelu płytkowego. Dodatkowo, dzięki odpowiedniemu wyposażeniu w nowoczesną aparaturę, ma możliwość 
wykonywania specjalistycznych badań z zakresu krwiodawstwa i krwiolecznictwa.

Działalność naukowa Zakładu dotyczy zarówno zagadnień związanych $\mathrm{z}$ leczeniem krwią ( $\mathrm{w}$ tym także $z$ występowaniem powikłań poprzetoczeniowych nie tylko w Instytucie, ale także w całej Polsce), jak i metodyki pobierania, preparatyki, przechowywania, transportu i kontroli jakości krwi i jej składników. Działalność naukowa obejmuje także zagadnienia związane $z$ przygotowywaniem HSC jako materiału przeszczepowego. Zespół Zakładu prowadzi prace nad kliniczną oceną właściwości hemostatycznych i możliwościami zastosowania w lecznictwie autologicznych i allogenicznych preparatów kleju fibrynowego i żelu płytkowego. Ponadto bierze udział $\mathrm{w}$ badaniach służących ocenie jakości i bezpieczeństwa stosowania składników krwi przechowywanych w roztworach wzbogacających, poddawanych napromienianiu, inaktywacji i innym nowo wprowadzonym do krwiodawstwa procedurom. Zakład Transfuzjologii ściśle współpracuje z Zakładem Wirusologii i Zakładem Immunologii Hematologicznej i Transfuzjologicznej w zakresie krwiodawstwa i krwiolecznictwa oraz z Zakładem Immunogenetyki w zakresie zagadnień związanych $z$ dawcami HSC.

Zakład prowadzi także działalność szkoleniową, organizując i uczestnicząc w prowadzeniu kursów $z$ zakresu krwiodawstwa i krwiolecznictwa dla personelu zatrudnionego $\mathrm{w}$ jednostkach organizacyjnych publicznej służby krwi oraz dla diagnostów laboratoryjnych $\mathrm{w}$ ramach specjalizacji $\mathrm{z}$ laboratoryjnej transfuzjologii medycznej. We współpracy z Kliniką Hematologii i Transfuzjologii Centrum Medycznego Kształcenia Podyplomowego (CMKP) pracownicy Zakładu biorą udział w kursach dla lekarzy w ramach specjalizacji $z$ transfuzjologii klinicznej, hematologii, onkologii klinicznej i chorób wewnętrznych. Zakład prowadzi również szkolenia indywidualne.

W skład Zakładu wchodzą: Pracownia Transfuzjologii Klinicznej z Bankiem Krwi, Pracownia Transfuzjologii Laboratoryjnej z Bankiem Komórek Krwiotwórczych, Pracownia Zapewnienia Jakości, Pracownia Organizacji Służby Krwi, Pracownia Mikrobiologii oraz Ośrodek Dawców Szpiku.

\section{Pracownia Transfuzjologii Laboratoryjnej z Bankiem Komórek Krwiotwórczych}

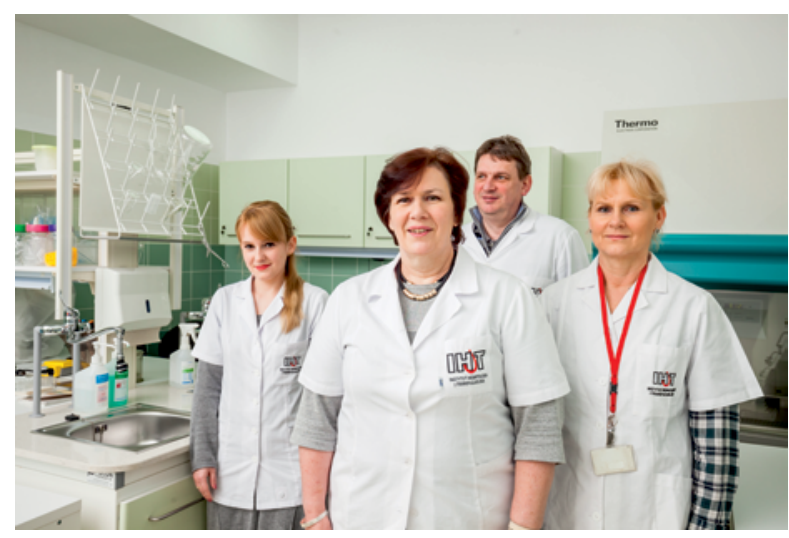

Kierownik: dr n. farm. Jolanta Antoniewicz-Papis

Zespół: mgr Marta Gawryś, mgr Karolina Pieńko, st. tech. Małgorzata Pawlik

Adres: ul. Indiry Gandhi 14, 02-776 Warszawa

tel.: 223496 381; 223496 388; 223496389

e-mail: ptlzbkk@ihit.waw.pl

W strukturach Pracowni działa Bank Komórek Krwiotwórczych, który zajmuje się testowaniem, przetwarzaniem (preparatyka i kriokonserwacja), przechowywaniem oraz wydawaniem HSC pocho- dzących ze szpiku oraz krwi obwodowej, a także allogenicznej krwi pępowinowej. Pracownia ma pomieszczenia banku o klasie czystości A.

Pracownia ma akredytację Ministerstwa Zdrowia na pozyskiwanie, przetwarzanie i przechowywanie HSC uzyskaną w wyniku potwierdzenia spełnienia wymagań prawnych i jakościowych, zgodnie $z$ ustawą o pobieraniu, przechowywaniu i przeszczepianiu komórek, tkanek i narządów.

W Pracowni są wykonywane specjalistyczne preparaty autologiczne wykorzystywane między innymi w leczeniu objawów zespołu suchego oka (,sztuczne łzy”) oraz w leczeniu choroby hemolitycznej płodu/noworodka w konfliktach matczyno-płodowych (koncentraty krwinek płytkowych oraz koncentraty krwinek czerwonych).

Pracownicy Pracowni biorą udział w szkoleniach organizowanych przez Zakład $z$ zakresu krwiodawstwa i krwiolecznictwa oraz bankowania HSC przeznaczonych do przeszczepienia; sa autorami licznych publikacji, a także biorą udział w przeprowadzaniu kontroli w jednostkach organizacyjnych publicznej służby krwi. 


\section{Pracownia Transfuzjologii Klinicznej z Bankiem Krwi}

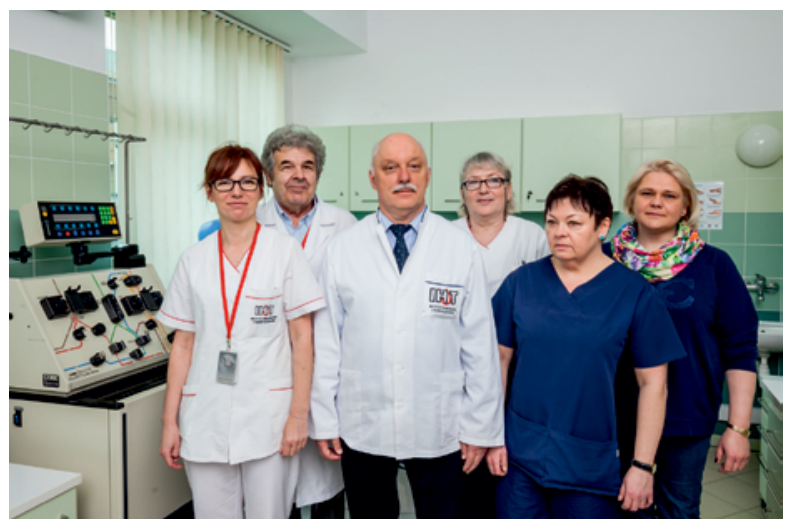

Kierownik: prof. dr hab. n. med. Ryszard Pogłód Zespół: lek. Lech Rzymkiewicz, mgr Beata Wiśniewska (oddziałowa), mgr Ewa Pietrowiak, mgr Milena Prusaczyk, Iwona Dziarnowska, Bożena Knyt, Monika Matusz, Ewa Szczepańska, Marzena Wójcik, Elżbieta Zawirska
Adres: ul. Indiry Gandhi 14, 02-776 Warszawa tel. 223496 556; 223496 533; 223496569 e-mail: rpoglod@ihit.waw.pl

W Pracowni są wykonywane zabiegi lecznicze plazmaferezy, trombaferezy i leukaferezy. Pracownia działa również jako ośrodek pobierający HSC $z$ krwi obwodowej od niespokrewnionych dawców. Prowadzi w tym zakresie współpracę $z$ różnymi ośrodkami dawców szpiku. W Pracowni jest pobierana krew autologiczna i jej składniki w celu uzyskania specjalistycznych preparatów. Ponadto Pracownia zajmuje się zaopatrzeniem w krew i jej składniki wszystkich potrzebujących chorych przebywających w klinikach i na oddziałach Instytutu. Udziela również konsultacji w zakresie leczenia krwią, jej składnikami i produktami krwiopochodnymi.

\section{Ośrodek Dawców Szpiku}

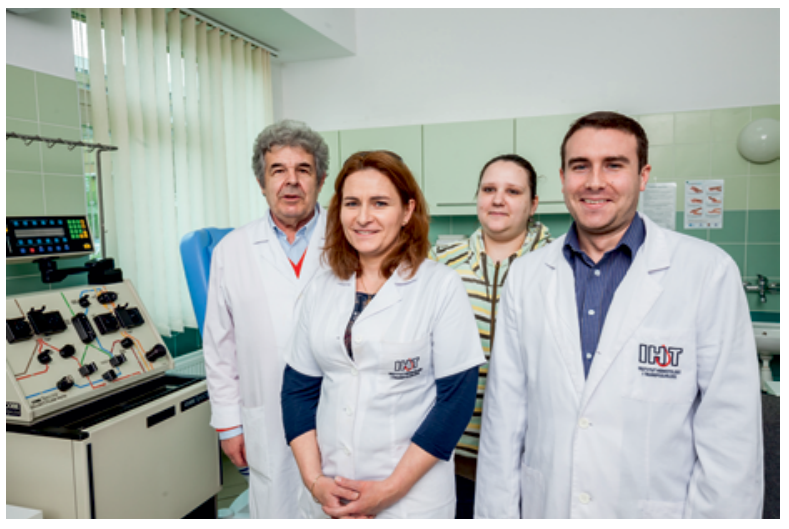

Kierownik: lek. Monika Grzegorek

Zespół: mgr Aleksandra Czajkowska, mgr Tomasz Jankowski, mgr Martyna Romańska-Płużańska
Adres: ul. Indiry Gandhi 14, 02-776 Warszawa tel.: 223496 375; 223496 376; 223496 380; $223496390 ; 223496391$

e-mail: ods@ihit.waw.pl

Ośrodek Dawców Szpiku prowadzi działalność edukacyjną $\mathrm{i}$ informacyjną $\mathrm{w}$ zakresie promocji dawstwa HSC od osób niespokrewnionych. Rekrutuje i bada nowych dawców HSC, uczestniczy w ich ostatecznej kwalifikacji, a także koordynuje opiekę zdrowotną nad dawcą po pobraniu komórek. Uczestniczy również $\mathrm{w}$ akcjach rekrutacyjnych potencjalnych dawców szpiku.

\section{Pracownia Zapewnienia Jakości}

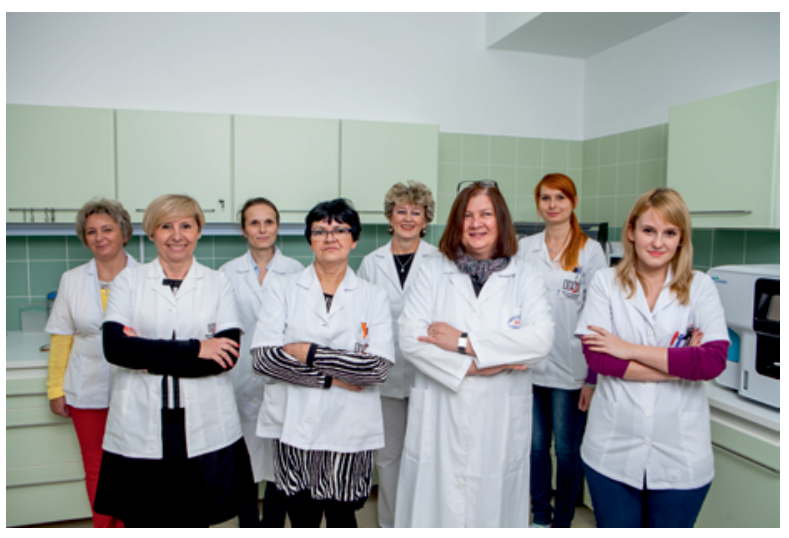

\section{Kierownik: dr $\mathbf{n}$. farm. Elżbieta Lachert}

Zespół: dr n. farm. Jolanta Kubis - specjalista laboratoryjnej transfuzjologii medycznej, mgr Ewa Potocka, mgr Agata Płodzich, st. tech. Elżbieta Wiśniakowska, Marzena Kłokocka, Elżbieta Kowalczyk Adres: ul. Indiry Gandhi 14, 02-776 Warszawa tel.: 223496 382; 223496 386; 223496387 e-mail: bloodorg2@ihit.waw.pl

W Pracowni są prowadzone badania kontroli jakości składników krwi otrzymywanych w jednostkach organizacyjnych publicznej służby krwi i kontroli seryjnej wstępnej produktów krwiopochodnych. 
Pracownia sprawuje nadzór nad organizacją kontroli $\mathrm{w}$ jednostkach organizacyjnych publicznej służby krwi oraz nadzoruje walidację procesu przechowywania krwi i jej składników, a także odczynników i próbek do badań w urządzeniach chłodniczych. Prowadzi również kontrolę jakości składników krwi magazynowanych w Banku Krwi Instytutu. W Pracowni jest analizowana dokumentacja dotycząca produktów krwiopochodnych w ramach procedury OCABR — kontrola merytoryczna.

W ramach działalności usługowej w Pracowni są także prowadzone badania służące ocenie aparatury i sprzętu jednorazowego użytku pod kątem ich przydatności w CKiK oraz jest wykonywana preparatyka autologicznych koncentratów fibrynogenu i żeli płytkowych.

Działalność naukowa Pracowni dotyczy zagadnień związanych $z$ preparatyką i warunkami przechowywania krwi i jej składników, optymalizacją metod otrzymywania autologicznych koncentratów fibrynogenu i autologicznych żeli płytkowych.

Pracownia Zapewnienia Jakości organizuje kursy dla diagnostów laboratoryjnych przygotowujących się do egzaminu specjalizacyjnego $z$ dziedziny laboratoryjnej transfuzjologii medycznej oraz szkolenia wewnętrzne dla personelu Zakładu Transfuzjologii.

\section{Pracownia Organizacji Służby Krwi}

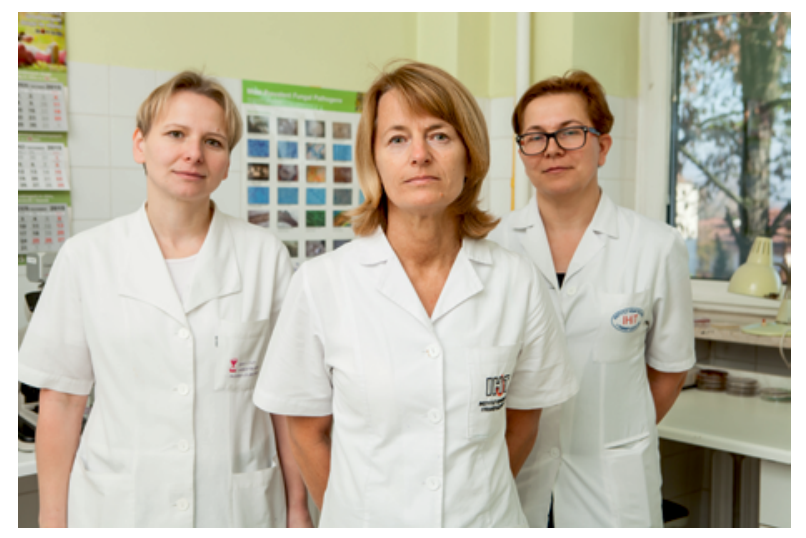

Kierownik: mgr Anna Tomaszewska

Zespół: dr n. med. Aleksandra Rosiek, mgr Krystyna Dudziak, inż. Krzysztof Sutkowski, Paweł Kłobukowski
Adres: ul. Indiry Gandhi 14, 02-776 Warszawa tel.: 223496 377; 223496 379; 223496 384; $223496401 ; 223496482$

e-mail: antomaszewska@ihit.waw.pl

Pracownia prowadzi działalność organizacyjno-merytoryczną wynikającą z zadań określonych $\mathrm{w}$ ustawie o publicznej służbie krwi. W zakres tej działalności wchodzą, między innymi, prowadzenie Krajowego Rejestru Dawców Krwi oraz analiza zgłoszonych reakcji poprzetoczeniowych i niepożądanych zdarzeń. Do zadań Pracowni należy również opracowywanie rocznego raportu dla EDQM i OMCL Network na podstawie badań wykonywanych w ramach kontroli seryjnej wstępnej.

\section{Pracownia Mikrobiologii}

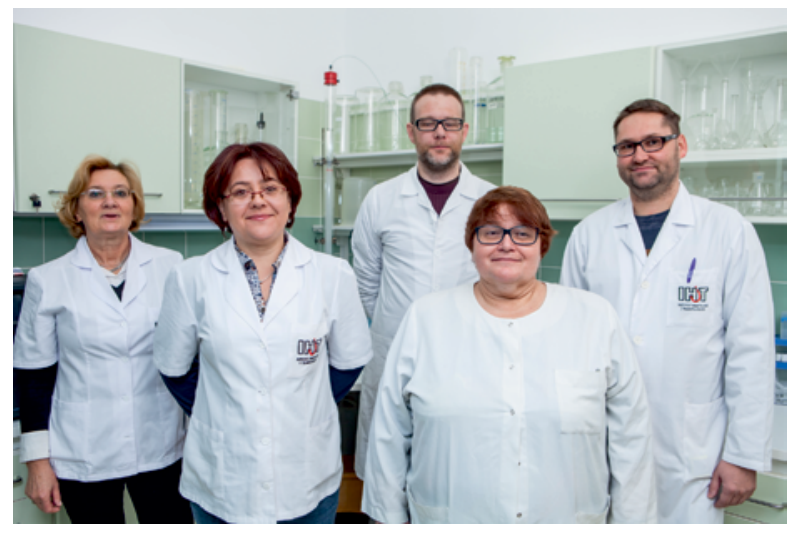

Kierownik: mgr Ewa Mik

Zespół: mgr Anna Kuziak - specjalista mikrobiologii medycznej, st. tech. Bożena Wasilewska, Elżbieta Kępka Adres: ul. Chocimska 5, 02-776 Warszawa

tel.: 223496 616; 223496641

e-mail:emik@ihit.waw.pl
W Pracowni Mikrobiologii jest prowadzona diagnostyka bakteriologiczna i mykologiczna na rzecz klinik i oddziałów Instytutu oraz odbiorców zewnętrznych. Badania są wykonywane w systemie automatycznym za pomoca analizatora mikrobiologicznego VITEK 2 COMPACT, co zapewnia wiarygodność i powtarzalność wyników. Posiewy krwi i innych płynów ustrojowych są wykonywane w systemie automatycznym Bactec 9050 oraz BactAlert, co pozwala na szybką ocenę dodatnich próbek krwi i umożliwia ukierunkowanie terapii przez klinicystów.

Pracownia przekazuje wyniki badań dodatnich i patogenów alarmowych Zespołowi Kontroli Zakażeń Szpitalnych i oddziałom Instytutu. Ponadto przygotowuje i przedstawia klinikom sytuację mikrobiologiczną oraz trendy narastania oporności. Pracownia systematycznie uczestniczy w zewnętrznej kontroli jakości Polmicro i ma certyfikaty wiarygodności badań w mikrobiologii. 
Pracownia Mikrobiologii wykonuje badania mikrobiologiczne wszystkich materiałów klinicznych: tj. krwi, płynów ustrojowych, ropy, plwociny, moczu, kału, wymazów z gardła, nosa i oka w zakresie: 1) identyfikacji:

- pałeczek Gram-ujemnych z rodziny Enterobacteriaceae i pałeczek niefermentujących do gatunku,

- B-hemolizujących paciorkowców z grup A, B, C, D, F, G, pneumokoków i enterokoków,

- pałeczek hemofilnych,

- dwoinek zapalenia opon mózgowo-rdzeniowych,

- drobnoustrojów beztlenowych;

2) różnicowania gronkowców na koagulazoujemne i koagulazododatnie - identyfikacji do gatunku gronkowców izolowanych $z$ krwi i płynów ustrojowych;

3) oznaczania wrażliwości na antybiotyki i chemioterapeutyki wyizolowanych drobnoustro- jów zgodnie $z$ zaleceniami EUCAST i Krajowego Ośrodka Referencyjnego ds. Lekowrażliwości Drobnoustrojów metodami: dyfuzyjno-krążkową, automatyczną (system VITEK), E-testu (oznaczenie minimalnych stężeń hamujących);

4) wykrywania mechanizmów oporności:

- metycylinooporności gronkowców;

- oporności gronkowców i enterokoków na glikopeptydy;

- wytwarzania ESBL przez pałeczki Gram-ujemne;

- wytwarzania ampC przez pałeczki Gram-ujemne;

- wytwarzania MBL przez pałeczki Gram-ujemne;

- wytwarzania KPC przez pałeczki Gram-ujemne;

- wytwarzania OXA-48 przez pałeczki Gram-ujemne.

\begin{tabular}{|c|c|c|}
\hline Rodzaj materiału & Kierunek badania & Przybliżony czas oczekiwania na wynik \\
\hline \multirow{3}{*}{$\begin{array}{l}\text { Krew, szpik, komórki ma- } \\
\text { cierzyste krwi obwodowej, } \\
\text { płyn mózgowo-rdzeniowy, } \\
\text { płyny z jam ciała (posiew } \\
\text { w systemie automatycz- } \\
\text { nym) }\end{array}$} & Bakterie tlenowe & $\begin{array}{l}\text { Brak wzrostu }-7 \text { dni } \\
\text { Posiew dodatni } z \text { antybiogramem }-72 \mathrm{~h}\end{array}$ \\
\hline & Bakterie beztlenowe & $\begin{array}{l}\text { Brak wzrostu }-7-10 \mathrm{dni} \\
\text { Posiew dodatni } z \text { antybiogramem }- \text { min. } 4 \text { dni }\end{array}$ \\
\hline & Grzyby drożdżopodobne & $\begin{array}{l}\text { Brak wzrostu }-10 \mathrm{dni} \\
\text { Posiew dodatni z mykogramem }- \text { min. } 4-6 \mathrm{dni}\end{array}$ \\
\hline \multirow{4}{*}{$\begin{array}{l}\text { Płyn mózgowo-rdzeniowy } \\
\text { pobrany do sterylnej pro- } \\
\text { bówki }\end{array}$} & Bakterioskopia & $2 \mathrm{~h}$ \\
\hline & Bakterie tlenowe & $\begin{array}{l}\text { Brak wzrostu }-3 \text { dni } \\
\text { Posiew dodatni } z \text { antybiogramem }-72 \mathrm{~h}\end{array}$ \\
\hline & Bakterie beztlenowe & $\begin{array}{l}\text { Brak wzrostu }-7 \text { dni } \\
\text { Posiew dodatni } z \text { antybiogramem }-\min .4 \text { dni }\end{array}$ \\
\hline & Grzyby drożdżopodobne & $\begin{array}{l}\text { Brak wzrostu }-7-10 \text { dni } \\
\text { Posiew dodatni z mykogramem }- \text { min. } 4-6 \text { dni }\end{array}$ \\
\hline \multirow{2}{*}{$\begin{array}{l}\text { Cewnik naczyniowy - me- } \\
\text { tody ilościowa (Brun-Bruis- } \\
\text { son) i półilościowa (Maki) }\end{array}$} & Bakterie tlenowe & $\begin{array}{l}\text { Brak wzrostu }-2 \text { dni } \\
\text { Posiew dodatni } z \text { antybiogramem }-72 \mathrm{~h}\end{array}$ \\
\hline & Grzyby drożdżopodobne & $\begin{array}{l}\text { Brak wzrostu }-7-10 \text { dni } \\
\text { Posiew dodatni z mykogramem }- \text { min. } 4-6 \text { dni }\end{array}$ \\
\hline \multirow[t]{2}{*}{ Mocz } & Bakterie tlenowe & $\begin{array}{l}\text { Brak wzrostu }-1 \text { dzień } \\
\text { Posiew dodatni } \mathrm{z} \text { antybiogramem }-72 \mathrm{~h}\end{array}$ \\
\hline & Grzyby drożdżopodobne & $\begin{array}{l}\text { Brak wzrostu }-7-10 \text { dni } \\
\text { Posiew dodatni z mykogramem }- \text { min. 4-6 dni }\end{array}$ \\
\hline \multirow{3}{*}{$\begin{array}{l}\text { Plwocina, BAL, aspirat } \\
\text { z dolnych dróg oddecho- } \\
\text { wych }\end{array}$} & Bakterioskopia & $2 \mathrm{~h}$ \\
\hline & $\begin{array}{l}\text { Bakterie tlenowe } z \text { wyjątkiem patogenów } \\
\text { wewnątrzkomórkowych }\end{array}$ & $\begin{array}{l}\text { Flora fizjologiczna }-2 \text { dni } \\
\text { Posiew dodatni } z \text { antybiogramem }-3 \text { dni }\end{array}$ \\
\hline & Grzyby drożdżopodobne & $\begin{array}{l}\text { Brak wzrostu }-7-10 \text { dni } \\
\text { Posiew dodatni z mykogramem }- \text { min. } 4-6 \text { dni }\end{array}$ \\
\hline \multirow[t]{2}{*}{$\begin{array}{l}\text { Wymazy z gardła, jamy ust- } \\
\text { nej, ucha }\end{array}$} & Bakterie tlenowe & $\begin{array}{l}\text { Flora fizjologiczna }-2 \text { dni } \\
\text { Posiew dodatni } z \text { antybiogramem }-3 \mathrm{dni}\end{array}$ \\
\hline & Grzyby drożdżopodobne & $\begin{array}{l}\text { Brak wzrostu }-7-10 \text { dni } \\
\text { Posiew dodatni z mykogramem }- \text { min. } 4-6 \text { dni }\end{array}$ \\
\hline
\end{tabular}




\begin{tabular}{|c|c|c|}
\hline Rodzaj materiału & Kierunek badania & Przybliżony czas oczekiwania na wynik \\
\hline $\begin{array}{l}\text { Wymazy z nosa i skóry (no- } \\
\text { sicielstwo) }\end{array}$ & Bakterie tlenowe & $\begin{array}{l}\text { Brak wzrostu }-48 \mathrm{~h} \\
\text { Posiew dodatni } \mathrm{z} \text { antybiogramem }-72 \mathrm{~h}\end{array}$ \\
\hline \multirow{3}{*}{$\begin{array}{l}\text { Materiały pobrane śród- } \\
\text { operacyjnie, wymazy z ran, } \\
\text { owrzodzenia, ropa }\end{array}$} & Bakterie tlenowe & $\begin{array}{l}\text { Brak wzrostu }-48 \mathrm{~h} \\
\text { Posiew dodatni } \mathrm{z} \text { antybiogramem }-72 \mathrm{~h}\end{array}$ \\
\hline & Bakterie beztlenowe & $\begin{array}{l}\text { Brak wzrostu }-7 \mathrm{dni} \\
\text { Posiew dodatni } z \text { antybiogramem }- \text { min. } 4 \text { dni }\end{array}$ \\
\hline & Grzyby drożdżopodobne & $\begin{array}{l}\text { Brak wzrostu }-7-10 \mathrm{dni} \\
\text { Posiew dodatni z mykogramem }- \text { min. } 4-6 \mathrm{dn}\end{array}$ \\
\hline \multirow[t]{3}{*}{ Kał } & $\begin{array}{l}\text { Obecność toksyny „A" } \mathrm{i} \text { „B" Clostridium } \\
\text { difficile }\end{array}$ & $2 \mathrm{~h}$ \\
\hline & $\begin{array}{l}\text { Obecność antygenów wirusów Rota i Ade- } \\
\text { no }\end{array}$ & $30 \mathrm{~min}$ \\
\hline & $\begin{array}{l}\text { Posiew w kierunku SS, ESBL, MBL, KPC, } \\
\text { VRE, MRSA }\end{array}$ & $\begin{array}{l}\text { Brak wzrostu }-2 \text { dni } \\
\text { Posiew dodatni }- \text { min. } 3 \text { dni }\end{array}$ \\
\hline $\begin{array}{l}\text { Wymazy ze środowiska } \\
\text { szpitalnego }\end{array}$ & Bakterie tlenowe & $\begin{array}{l}\text { Brak wzrostu }-2 \text { dni } \\
\text { Posiew dodatni }- \text { min. } 3 \text { dni }\end{array}$ \\
\hline \multirow[t]{2}{*}{$\begin{array}{l}\text { Badanie jałowości powie- } \\
\text { trza }\end{array}$} & Bakterie tlenowe & $\begin{array}{l}\text { Brak wzrostu }-2 \text { dni } \\
\text { Posiew dodatni }-2 \text { dni }\end{array}$ \\
\hline & Grzyby pleśniowe & $\begin{array}{l}\text { Brak wzrostu }- \text { min. } 5 \mathrm{dni} \\
\text { Posiew dodatni }-10 \mathrm{dni}\end{array}$ \\
\hline
\end{tabular}

\section{ZAKŁAD DIAGNOSTYKI HEMATOLOGICZNEJ}

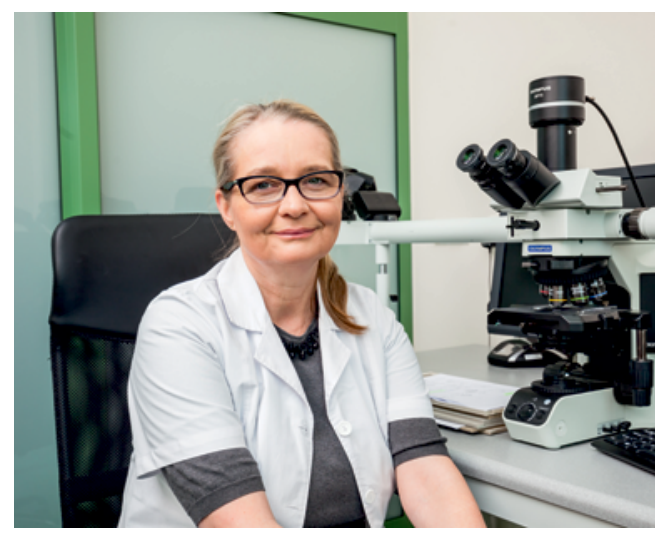

Kierownik: prof. dr hab. n. med. Monika Prochorec-Sobieszek

Adiunkci: dr n. med. Urszula Podstawka, dr n. med. Anna Szumera-Ciećkiewicz, dr Patryk Górniak Lekarze: lek. Olga Szymańska-Giemza

Diagności laboratoryjni: dr $n$. biol. Urszula Bany-Łaszewicz, dr n. med. Katarzyna Borg, dr n. med. Iwona Solarska, dr n. med. Jolanta Woźniak, mgr Agnieszka Gajewska, mgr Danuta Gwóźdź, mgr Barbara Kruk, mgr Agnieszka Krzywdzińska, mgr Ewelina Franecka, mgr Hanna Makuch-Łasica, mgr Ewa Migal, mgr Grażyna Nowak Biolodzy: mgr inż. Aleksandra Bluszcz, mgr Edyta Derezińska, mgr Bożena Rawska, dr n. biol. Magdalena Wojtas

Adres: ul. Indiry Gandhi 14, 02-776 Warszawa tel.: 223496 296; 223496495

faks 223496494

e-mail: diaghem@ihit.waw.pl

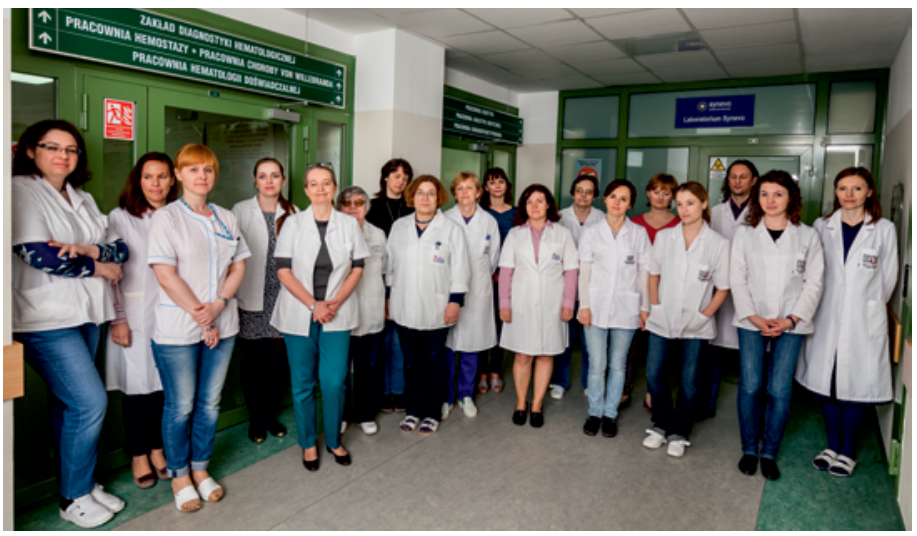

Technicy: st. tech. Barbara Bielecka, inż. Agata Bielińska, tech. Iwona Kania, mgr inż. Renata Miąsko, st. tech. Monika Okła, st. tech. Robert Ziętek, st. tech. Halina Wicher

Sekretariat: mgr Iwona Sosnowska

Konsultant: prof. dr hab. n. med. Maria Kraj

W Zakładzie Diagnostyki Hematologicznej są prowadzone prace naukowe i działalność usługowa w zakresie patogenezy i diagnostyki chorób układów krwiotwórczego i chłonnego oraz działalność szkoleniowa i konsultacyjna w tym zakresie. W Zakładzie wykonuje się kompleksową, wielospecjalistyczną diagnostykę i monitoruje leczenie chorych $z$ chorobami układów krwiotwórczego i chłonnego zgodnie $z$ wytycznymi i według standardów krajowych i międzynarodowych towarzystw naukowych i grup 
roboczych, Światowej Organizacji Zdrowia i European LeukemiaNet. Zadania diagnostyczne w Zakładzie są wykonywane w ramach ścisłej współpracy między poszczególnymi pracowniami Zakładu i Klinikami Instytutu. W ramach diagnostyki w pracowniach $\mathrm{Za}-$ kładu są wykonywane badania cytologiczne, cytochemiczne i cytoenzymatyczne oraz oznaczane markery cytofluorometryczne, cytogenetyczne i molekularne. Wykonuje się w nim również oznaczenia choroby resztkowej w białaczkach i chłoniakach metodami cytometrii przepływowej i molekularnymi.

Naukowa aktywność Zakładu wiąże się z jego działalnością usługowo-diagnostyczną i dotyczy optymalizacji metod diagnostyki i monitorowania skuteczności leczenia u chorych na nowotwory układów krwiotwórczego i chłonnego oraz mechanizmów patogenetycznych $\mathrm{i}$ identyfikacji racjonalnych celów terapeutycznych w tych chorobach. Do zadań Zakładu należy również bankowanie i archiwizowanie tkanek, komórek oraz wyizolowanego materiału biologicznego do badań naukowych. W zakresie prowadzonych projektów badawczych Zakład ściśle współpracuje $z$ klinikami i oddziałami Instytutu oraz z Zakładem Hematologii Eksperymentalnej.

W skład Zakładu wchodzą: Pracownia Analityki Medycznej, Pracownia Immunofenotypowania, Pracownia Cytogenetyki, Pracownia Biologii Molekularnej oraz Pracownia Patomorfologii.

\section{Pracownia Analityki Medycznej}

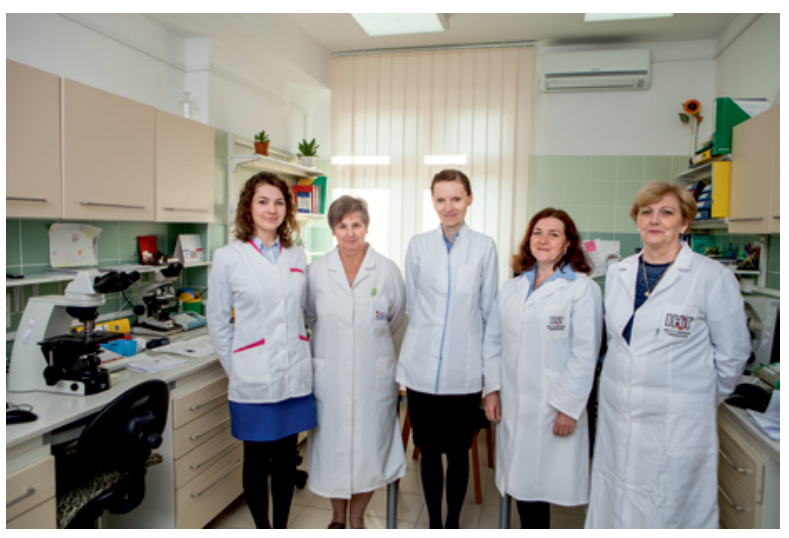

\section{Kierownik: mgr Ewa Migal}

Zespół: mgr Danuta Gwóźdź (diagnosta laboratoryjny), dr n. med. Barbara Kruk (diagnosta laboratoryjny), mgr Eliza Zaremba (specjalista laboratoryjnej diagnostyki medycznej), Barbara Bielecka (st. tech. analityki medycznej), Halina Wicher (st. tech. analityki medycznej) Adres: ul. Indiry Gandhi 14, 02-776 Warszawa tel. 223496162

e-mail: pak@ihit.waw.pl

W Pracowni są wykonywane badania $z$ zakresu hematologicznej diagnostyki chorób układów krwiotwórczego i chłonnego, w tym:

- cytomorfologiczna ocena rozmazów krwi obwodowej i szpiku;

- ocena aktywności fosfatazy zasadowej granulocytów krwi obwodowej;

- ocena aktywności fosfatazy kwaśnej opornej na winian;

- ocena aktywności esterazy nieswoistej;

- ocena aktywności peroksydazy;
- barwienie z Sudanem Czarnym B;

- reakcja PAS;

- wykrywanie syderoblastów/syderoblastów pierścieniowatych $\mathrm{w}$ preparatach szpiku;

- ocena płytek z rozmazu krwi obwodowej;

- immunofiksacja surowicy i moczu;

- oznaczanie stężeń IgA, IgM, IgD, IgE w surowicy;

- oznaczanie stężenia $\beta_{2}$-mikroglobuliny w surowicy;

- oznaczanie stężenia wolnych lekkich łańcuchów $\kappa$ i $\lambda$ w surowicy.

Do Pracowni Analityki Medycznej dostarczane są dwa rodzaje materiałów biologicznych - krew i szpik. Zależnie od rodzaju badań, jakie mają być wykonane, powinna być dostarczona krew pełna pobrana na EDTA bądź gotowe rozmazy krwi lub szpiku; wykonuje się:

- ocenę cytologiczna krwi obwodowej (krew pełna/rozmaz krwi);

- ocenę cytologiczną szpiku (dwa niebarwione rozmazy szpiku prawidłowo opisane imieniem i nazwiskiem pacjenta, $z$ datą pobrania);

- oznaczenie fosfatazy alkalicznej granulocytów (krew pełna/dwa niebarwione rozmazy krwi);

- oznaczenie syderoblastów (dwa niebarwione rozmazy szpiku);

- badania cytochemiczne i cytoenzymatyczne (4-6 niebarwionych preparatów krwi lub szpiku).

Pracownia od wielu lat uczestniczy w Programie Zewnętrznej Oceny Jakości w zakresie mikroskopowego badania rozmazu krwi obwodowej i szpiku kostnego (EQA-hem). 


\section{Pracownia Immunofenotypowania}

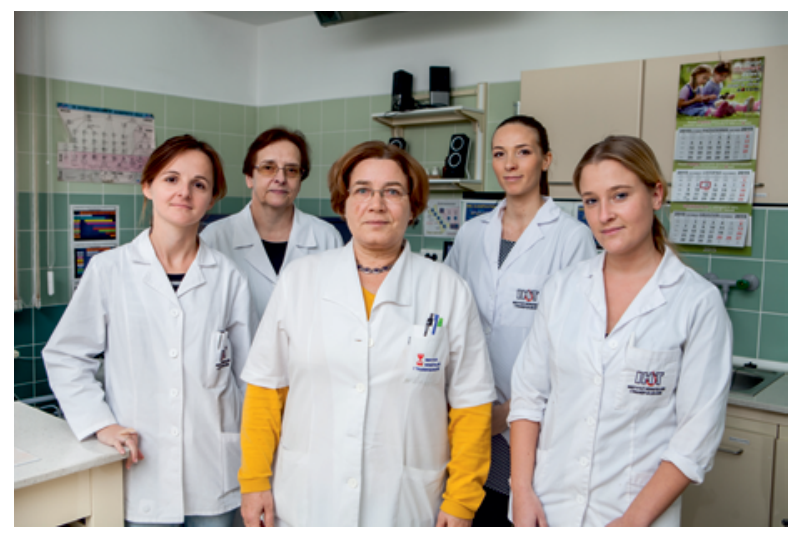

Kierownik: dr n. med. Jolanta Woźniak

Zespół: mgr Ewelina Franecka, mgr Agnieszka Krzywdzińska, dr n. med. Urszula Podstawka Adres: ul. Indiry Gandhi 14, 02-776 Warszawa tel. 223496 164; 223496 166; 223496167 e-mail: cytometr@ihit.waw.pl

W Pracowni są wykonywane badania powierzchniowych i cytoplazmatycznych antygenów komórek krwi i szpiku u pacjentów $z$ chorobami układów krwiotwórczego i chłonnego metodą cytometrii przepływowej. Badania wykonuje się w cytometrze przepływowym Canto (8 kolorów) firmy Becton Dickinson w oparciu o protokoły dostępne $\mathrm{w}$ piśmiennictwie oraz wytyczne specjalistycznych polskich i międzynarodowych grup badawczych, a także własne 20-letnie doświadczenie. Wartości referencyjne stanowią immunofenotyp komórek i rozkład subpopulacji leukocytów oznaczone we krwi i szpiku zdrowych dawców oraz w szpiku regenerującym się po chemioterapii.

W Pracowni wykonuje się badania określające immunofenotyp leukocytów metodą wielokolorowej cytometrii przeplywowej w celu:

- ustalenia fenotypu komórek nowotworowych w ostrych białaczkach szpikowych i limfoblastycznych wraz $z$ ustaleniem fenotypów aberrantnych (,puste pola”);

- ustalenia fenotypu komórek nowotworowych w nowotworach układu chłonnego;

- analizy cytometrycznej szpiku w zespołach mielodysplastycznych i nowotworach mieloproliferacyjnych;

- monitorowania leczenia, oceny występowania choroby resztkowej w nowotworach układów krwiotwórczego i chłonnego;

- oceny rozkładu subpopulacji leukocytów w badanym materiale;

- oceny podstawowych subpopulacji limfocytów, obejmującej rozkład odsetkowy i ocenę liczby bezwzględnej limfocytów T, B, NK oraz limfocytów T pomocniczych i supresorowych;

- oceny subpopulacji komórek NK w boreliozie $(\mathrm{CD} 57+)$;

- ustalenia odsetka i żywotności komórek CD34+ (produkty aferezy, szpik).

Materiał stanowią:

- krew obwodowa, aspirat szpiku - pobrane na EDTA;

- płyn mózgowo-rdzeniowy, BAL, materiał $z$ biopsji cienkoigłowej, inne płyny ustrojowe i wysiękowe - pobrane do probówki polipropylenowej bez antykoagulantu/sterylnego naczynka $z$ polipropylenu;

- węzeł chłonny - umieszczony w soli fizjologicznej o temp. $37^{\circ} \mathrm{C}$.

\section{Pracownia Cytogenetyki}

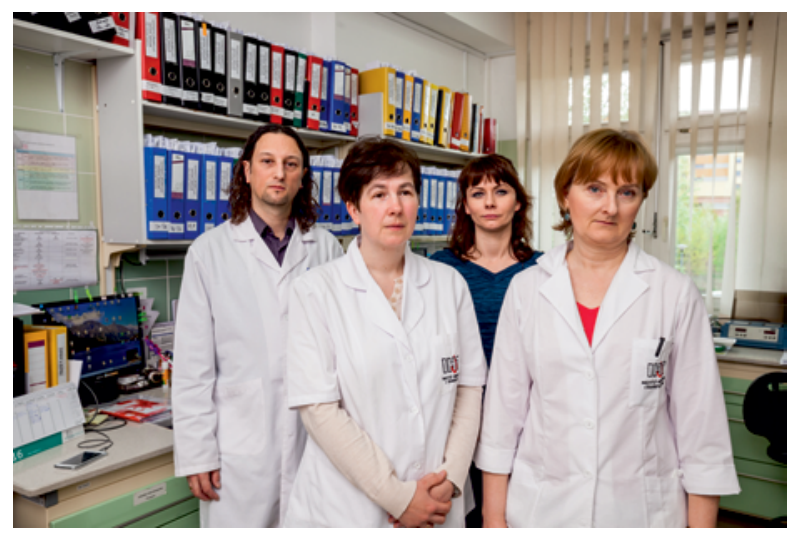

Kierownik: dr n. med. Katarzyna Borg

Zespół: dr n. biol. Urszula Bany-Łaszewicz, mgr inż. Aleksandra Bluszcz, mgr Agnieszka Gajewska, st. tech. Robert Ziętek

Adres: ul. Indiry Gandhi 14, 02-776 Warszawa tel.: 223496 173; 223496593

e-mail: genetyka@ihit.waw.pl

Pracownia wykonuje badania cytogenetyczne w nowotworowych chorobach układu krwiotwórczego i chłonnego. Analiza chromosomowa prowadzona jest $z$ zastosowaniem prążkowych metod cytogenetyki klasycznej (GTG) oraz techniki fluorescencyjnej hybrydyzacji in situ (FISH). Pracownia wykonuje również analizę kariotypu o wysokiej rozdzielczości prążkowej (HRT) stanowiącej podstawę postnatalnej diagnostyki specyficznych chorób i zespołów klinicznych uwarunkowanych aberracjami chromosomowymi. Laboratorium wyposażone jest $\mathrm{w}$ mikroskopy, sprzężone $z$ systemem automatycznego wyszukiwania metafaz oraz komputerowym systemem rejestracji, opraco- 
wywania i dokumentacji wyników badań kariotypu i FISH. Pracownia Cytogenetyki, zgodnie $z$ rozporządzeniem ministra zdrowia (Dz. U. z 2006 r., nr 61, poz. 435), spełnia standardy jakości w zakresie czynności laboratoryjnej diagnostyki medycznej oraz interpretacji i autoryzacji wyników badań.
Badania wykonywane są zgodnie $z$ zaleceniami i wytycznymi specjalistycznych międzynarodowych grup badawczych i/lub protokołami dostępnymi $\mathrm{w}$ renomowanym piśmiennictwie.

Badania wykonywane w Pracowni Cytogenetyki podano $\mathrm{w}$ poniższej tabeli.

\begin{tabular}{|l|l|l|}
\hline Rodzaj badania & Metoda & Materiał \\
\hline Ocena kariotypu & GTG & Szpik kostny, heparyna \\
\hline $\begin{array}{l}\text { Badanie FISH z sondą genową: BCR-ABL1, AML1-ETO, CBFB, PML-RARA, } \\
\text { MLL, ETV6, FIP1L1-CHIC2-PDGFRA, del(7q), del(5q), del(20q), MYB, MALT, } \\
\text { IGH, IGH-CCND1, FGFR3-IGH lub IGH-MAF }\end{array}$ & FISH & Krew/szpik kostny, heparyna \\
\hline Badanie metodą FISH genu fuzyjnego PCM1-JAK2 (diagnostyka eozynofilii) & FISH & Szpik kostny, heparyna \\
\hline Ocena chimeryzmu chromosomów płci (XY) & FISH & Szpik kostny, heparyna \\
\hline $\begin{array}{l}\text { Badanie metodą FISH w skrawkach parafinowych } \\
\text { Diagnostyka szpiczaka plazmocytowego; CD138+ } \\
\text { Panel MM: delTP53, rearanżacje genu IgH [t(4;14), t(14;16)] }\end{array}$ & FISH & $\begin{array}{l}\text { Utrwalony materiał w bloczku } \\
\text { parafinowym }\end{array}$ \\
\hline $\begin{array}{l}\text { Diagnostyka przewlekłej białaczki limfocytowej } \\
\text { Panel FISH: TP53, ATM, del(13q), cen12 }\end{array}$ & FISH & Szpik kostny, heparyna \\
\hline $\begin{array}{l}\text { Diagnostyka zmian wrodzonych } \\
\text { Ocena kariotypu }\end{array}$ & FISH & Krew, heparyna \\
\hline
\end{tabular}

\section{Pracownia Biologii Molekularnej}

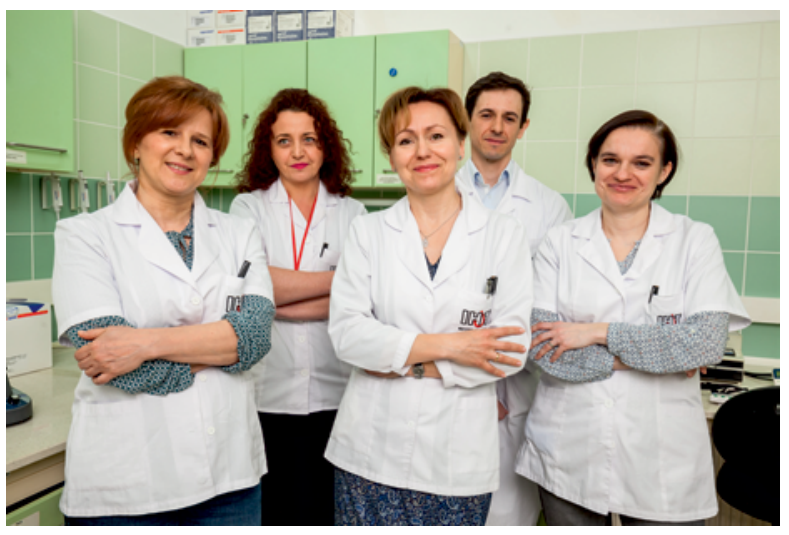

W Pracowni są wykonywane badania jakościowe i ilościowe metodami biologii molekularnej, które umożliwiają identyfikację strukturalnych zmian DNA i ekspresji genów zaangażowanych w patogenezę chorób hematoonkologicznych. Monitorowanie minimalnej choroby resztkowej metodą RQ-PCR z zastosowaniem technologii TaqMan
Kierownik: dr n. med. Patryk Górniak

Zespół: dr n. med. Iwona Solarska, dr n. biol. Magdalena Wojtas, mgr Hanna Makuch-Łasica, mgr Grażyna Nowak, tech. Iwona Kania

Adres: ul. Indiry Gandhi 14, 02-776 Warszawa tel.: 223496 170; 223496 171; 223496594 e-mial: molbiol@ihit.waw.pl

wykonuje się według protokołu międzynarodowego badania Europe Against Cancer oraz wytycznych ELN. Pracownia uczestniczy także w polskich oraz europejskich projektach standaryzujących techniki biologii molekularnej.

Badania wykonywane w Pracowni Biologii Molekularnej podano $\mathrm{w}$ tabeli poniżej. 


\begin{tabular}{|c|c|c|}
\hline Rodzaj badania & Metoda & Materiał \\
\hline \multicolumn{3}{|c|}{ Diagnostyka i monitorowanie przewlekłej białaczki szpikowej } \\
\hline Diagnostyka przewlekłej białaczki szpikowej (p210, p190, p230) & RT-PCR & Krew/szpik kostny EDTA \\
\hline Badanie MRD (pojedynczy transkrypt) & RT/nested-PCR i RQ-PCR & Krew/szpik kostny EDTA \\
\hline Badanie genu fuzyjnego $B C R-A B L 1$ & RT-PCR, RQ-PCR & Krew/szpik kostny EDTA \\
\hline Analiza mutacji KD BCR-ABL1 & Sekwencjonowanie cDNA & Krew/szpik kostny EDTA \\
\hline \multicolumn{3}{|c|}{ Diagnostyka ostrej białaczki szpikowej } \\
\hline $\begin{array}{l}\text { Diagnostyka ostrej białaczki szpikowej (AML1-ETO, CBFB-MYH11, } \\
\text { PML-RARA) }\end{array}$ & RT-PCR & Szpik kostny EDTA \\
\hline $\begin{array}{l}\text { Badanie pojedynczego genu fuzyjnego: AML1-ETO, MLL-AF4, } \\
\text { CBFB-MYH11, MLL-PTD lub PML-RARA }\end{array}$ & RT-PCR & Szpik kostny EDTA \\
\hline Badanie mutacji FLT3-ITD & PCR & Szpik kostny EDTA \\
\hline Ocena ekspresji genu $B A A L C$ & RQ-PCR & Szpik kostny EDTA \\
\hline Analiza mutacji genu NPM1 & Sekwencjonowanie DNA & Szpik kostny EDTA \\
\hline Analiza mutacji genu CEBPA & Sekwencjonowanie DNA & Szpik kostny EDTA \\
\hline Analiza mutacji genu $c K I T$ (eksony 8 i 17) & Sekwencjonowanie DNA & Szpik kostny EDTA \\
\hline \multicolumn{3}{|c|}{ Diagnostyka i monitorowanie ostrej białaczki limfoblastycznej } \\
\hline $\begin{array}{l}\text { Diagnostyka ostrej białaczki limfoblastycznej B komórkowej } \\
(B C R-A B L 1) \text { p190 i p210,TEL-AML1,E2A-PBX1, MLL-AF4) }\end{array}$ & RT-PCR & Szpik kostny EDTA \\
\hline $\begin{array}{l}\text { Diagnostyka ostrej białaczki limfoblastycznej T komórkowej } \\
(B C R-A B L 1) \text { p190 i p210, TEL-AML1,E2A-PBX1, SIL-TAL1) }\end{array}$ & RT-PCR & Szpik kostny EDTA \\
\hline $\begin{array}{l}\text { Badanie genu fuzyjnego: } B C R-A B L 1, T E L-A M L 1, E 2 A-P B X 1 \\
\text { lub SIL-TAL1 }\end{array}$ & RT-PCR & Szpik kostny EDTA \\
\hline $\begin{array}{l}\text { Identyfikacja jednego markera Ig/TCR do monitorowania choroby } \\
\text { resztkowej } \mathrm{ALL} \mathrm{Ph}(-)\end{array}$ & $\begin{array}{l}\text { Mutiplex-PCR, analiza hete- } \\
\text { rodupleksów, sekwencjono- } \\
\text { wanie DNA }\end{array}$ & Szpik kostny EDTA \\
\hline $\begin{array}{l}\text { Monitorowanie choroby resztkowej w ALL Ph(-) z zastosowaniem } \\
\text { pojedynczego markera Ig/TCR }\end{array}$ & RQ-PCR & Szpik kostny EDTA \\
\hline Klonalność limfocytów B i T & $\begin{array}{l}\text { Mutiplex-PCR, analiza hete- } \\
\text { rodupleksów }\end{array}$ & $\begin{array}{l}\text { Krew/szpik kostny EDTA } \\
\text { lub węzeł chłonny }\end{array}$ \\
\hline \multicolumn{3}{|c|}{ Diagnostyka nowotworów mieloproliferacyjnych } \\
\hline $\begin{array}{l}\text { Badanie genu fuzyjnego: } B C R-A B L 1, E T V 6-P D G F R B \\
\text { lub FIP1L1-PDGFRA }\end{array}$ & RT-PCR & Krew EDTA \\
\hline Badanie mutacji JAK2 V617F & ARMS-PCR & Krew EDTA \\
\hline Badanie mutacji MPL W515K/L & Sekwencjonowanie DNA & Krew EDTA \\
\hline Badanie mutacji CALR & sekwencjonowanie DNA & Krew EDTA \\
\hline Badanie mutacji KIT D816V (diagnostyka mastocytozy) & Sekwencjonowanie DNA & Szpik kostny EDTA \\
\hline \multicolumn{3}{|c|}{ Diagnostyka chłoniaków } \\
\hline Analiza mutacji MYD88 L265P & Sekwencjonowanie DNA & Krew/szpik kostny EDTA \\
\hline Analiza hipermutacji genów lgVH & Sekwencjonowanie DNA & $\begin{array}{l}\text { Krew/szpik kostny EDTA } \\
\text { lub węzeł chłonny }\end{array}$ \\
\hline Ocena ekspresji genu $Z A P-70$ & RQ-PCR & Krew/szpik kostny EDTA \\
\hline \multicolumn{3}{|c|}{ Diagnostyka zmian wrodzonych } \\
\hline $\begin{array}{l}\text { Analiza mutacji genu HFE (diagnostyka hemochromatozy, } \\
\text { eksony } 2 \text {, } 3 \text { i 4) }\end{array}$ & Sekwencjonowanie DNA & Krew, EDTA \\
\hline
\end{tabular}




\section{Pracownia Patomorfologii}

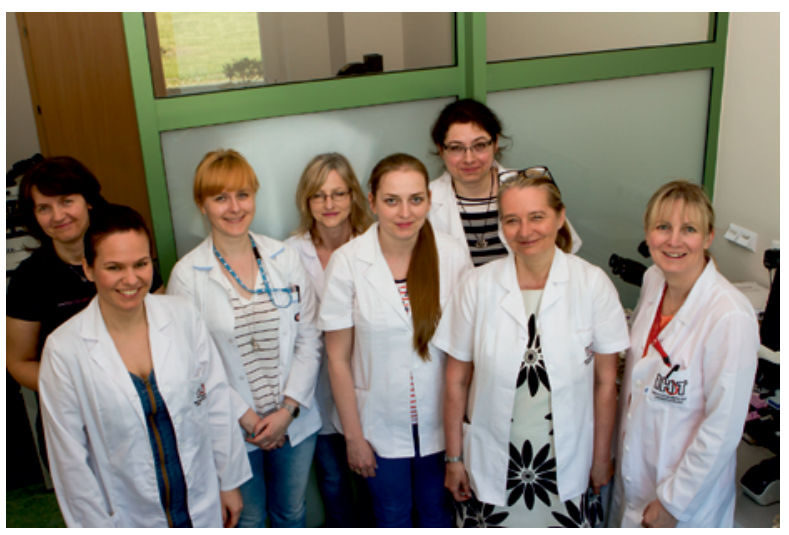

Kierownik: prof. dr. hab n. med. Monika Prochorec-Sobieszek

Zespół: dr n. med. Anna Szumera-Ciećkiewicz, lek. Olga Szymańska-Giemza, mgr Edyta Derezińska, mgr Bożena Rawska, inż. Agata Bielińska, mgr inż. Renata Miąsko, st. tech. Monika Okła Adres: ul. Indiry Gandhi 14, 02-776 Warszawa tel.: 223496 456; 223496457

e-mail: patomorfologia@ihit.waw.pl

W Pracowni są prowadzone prace naukowe oraz diagnostyczno-usługowe $\mathrm{z}$ zakresu diagnostyki i patogenezy chorób układów krwiotwórczego i chłonnego. Wykonuje się kompleksową, wielospecjalistyczną diagnostykę i monitorowanie leczenia chorych $z$ chorobami układów krwiotwórczego i chłonnego zgodnie $z$ wytycznymi i standardami krajowych i międzynarodowych towarzystw naukowych i grup roboczych, w tym WHO i ELN.

Pracownia Patomorfologii jest ośrodkiem o III stopniu referencyjności w zakresie hematopatologii. Proces wykonywania wycinków, barwienia oraz nakrywania szkiełek jest w pełni zautomatyzowany, co pozwala na pełną standaryzację jakości otrzymywanych preparatów. Pracownia ma akredytację Polskiego Towarzystwa Patologów w zakresie wykonywania oznaczeń immunohistochemicznych, a także regularnie uczestniczy w zewnętrznej kontroli jakości specjalistycznych barwień immunohistochemicznych. Pracownia jest również ośrodkiem konsultacyjnym dla całego kraju w dziedzinie hematopatologii, zwłasz- cza w zakresie diagnostyki histopatologicznej i immunohistochemicznej nowotworów układów chłonnego i krwiotwórczego. Pracownia prowadzi także działalność szkoleniową w ramach licznych kursów CMKP — zarówno dla klinicystów, jak i patologów oraz w ramach indywidualnych szkoleń.

Do zakresu procedur wykonywanych przez Pracownię Patomorfologii należą:

- badanie histopatologiczne trepanobioptatu $\mathrm{z}$ wykonaniem 1 bloczka/preparatu;

- badanie histopatologiczne materiału chirurgicznego $\mathrm{z}$ wykonaniem 1 bloczka/preparatu;

- ocena końcowa przez specjalistę hematopatologa $z$ wydaniem wyniku - trepanobiopsja, węzły chłonne;

- ocena końcowa przez specjalistę hematopatologa $z$ wydaniem wyniku - materiał chirurgiczny;

- konsultacja histopatologiczna nadesłanych preparatów;

- barwienie histochemiczne 1. preparatu Giemza;

- barwienie histochemiczne 1. preparatu Gomori;

- barwienie histochemiczne 1. preparatu Mucykarmin;

- barwienie histochemiczne 1. preparatu PAS;

- barwienie histochemiczne 1. preparatu Pratki;

- barwienie histochemiczne 1. preparatu Czerwień Kongo;

- barwienie histochemiczne 1 . preparatu metodą Perlsa;

- barwienie histochemiczne 1. preparatu Grocott;

- barwienie histochemiczne 1. preparatu Alcjan-PAS;

- barwienie histochemiczne 1. preparatu Azan-Trichrom;

- barwienie immunohistochemiczne 1. przeciwciała;

- barwienie immunohistochemiczne 1. przeciwciała manualnie;

- skrojenie 1. bloczka i wykonanie barwienia podstawowego $\mathrm{H} \& \mathrm{E}$;

- skrojenie bloczka parafinowego do badań genetycznych. 


\section{ZAKŁAD HEMOSTAZY I CHORÓB METABOLICZNYCH}

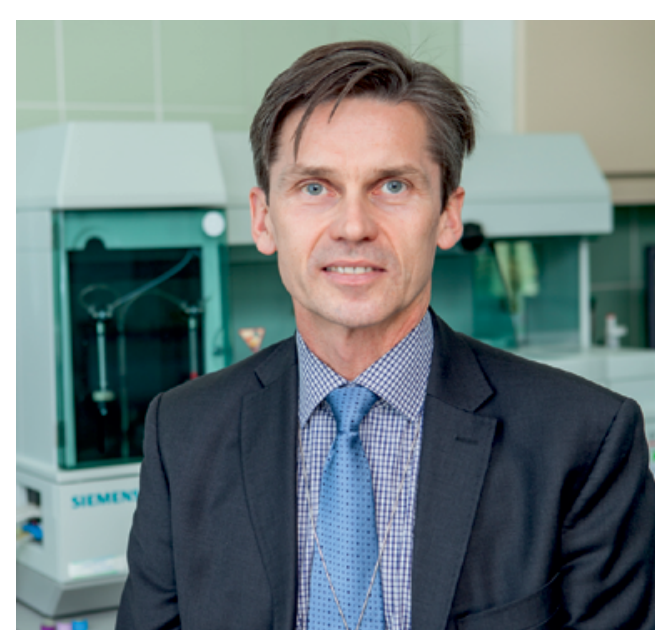

Kierownik: prof. dr hab. n. med. Jerzy Windyga

Profesor: prof. dr hab. n. med. Ksenia Bykowska

Diagności laboratoryjni: mgr Beata Baran, mgr Anna Bućko, dr n. med. Agnieszka Lipniacka, mgr Magdalena Marchewka, dr n. med. Edyta Odnoczko

Analitycy medyczni: mgr Ewelina Ejchman-Pac

Technicy: tech. Renata Bajszczak, st. tech. Irena Kamińska, tech. Anna Moszczyńska, st. tech. Anna Rurka, st. tech. Anna Sławińska

Pomoc laboratoryjna: Czesława Gładczuk, Katarzyna Lenart, Krystyna Ozimek

W ramach działalności Zakładu są wykonywane prace naukowe i usługi oraz prowadzone szkolenia i konsultacje na rzecz poradni specjalistycznych i klinik Instytutu oraz jednostek zewnętrznych w zakresie hemostazy i porfirii. W Zakładzie wykonuje się badania laboratoryjne stosowane w diagnostyce i monitorowaniu leczenia wrodzonych oraz nabytych zaburzeń hemostazy: hemofilii A i B, choroby von Willebranda i innych rzadkich skaz krwotocznych (np. niedobór czynników VII, XI, XIII), trombocytopatii, a także trombofilii. Poza rutynowymi testami hemostazy wykonuje się specyficzne testy umożliwiające badanie aktywności poszczególnych czynników krzepnięcia, aktywności i antygenu oraz multimetrów czynnika von Willebranda, aktywności i zawartości endogennych inhibitorów krzepnięcia. Pracownie wykonują również badania funkcji płytek krwi, oznaczenia aktywności i inhibitora metaloproteazy ADAMTS13 oraz testy globalne (badanie trom-

Adres: ul. Indiry Gandhi 14, 02-776 Warszawa tel.: 223496 157; 695336420

e-mail: jwindyga@ihit.waw.pl boelastometryczne skrzepu ROTEM Delta ${ }^{\circledR}$; test generacji trombiny TGA Technoclone ${ }^{\circledR}$ ). Ponadto w Zakładzie jest prowadzona diagnostyka molekularna: trombofilii (wykrywanie mutacji typu Leiden genu czynnika V, wykrywanie mutacji G20210A genu protrombiny, analiza sekwencyjna genu SERPINC1 - niedobór antytrombiny) oraz skaz krwotocznych, tj. hemofilii A (wykrywanie mutacji inwersyjnych [INV22 i INV1] i analiza sekwencji genu $F 8$ ), hemofilii B (analiza sekwencji genu F9), choroby von Willebranda (analiza sekwencji genu $V W F$ ) oraz niedoboru czynnika XI (analiza sekwencji genu $F 11$ ).

Zakład jest jedynym w Polsce ośrodkiem diagnostyczno-badawczym zajmującym się porfiriami i świadczy wysokospecjalistyczne usługi medyczne w zakresie rozpoznawania i różnicowania wszystkich typów porfirii w okresie objawowym choroby. Pracownia prowadzi także badania członków rodzin chorych na porfirię w celu wykrycia bezobjawowych nosicieli defektywnego genu oraz zajmuje się prowadzeniem krajowej bazy danych obejmujących chorych i członków ich rodzin, a także stale aktualizuje rejestr leków bezpiecznych i szkodliwych w porfirii.

Pracownie Zakładu cyklicznie poddają się zewnątrzlaboratoryjnej ocenie kontroli jakości badań laboratoryjnych $\mathrm{w}$ ramach takich programów, jak: Centralny Ośrodek Badań Jakości w Diagnostyce Laboratoryjnej (COBJwDL), ECAT Foundation External Quality Control of Diagnostic Assays and Tests with a Focus on Thrombosis and Haemostasis, European Porphyria Network (EPNET) EQAS.

W skład Zakładu wchodzą: Pracownia Hemostazy, Pracownia Choroby von Willebranda oraz Pracownia Porfirii. 


\section{Pracownia Hemostazy}

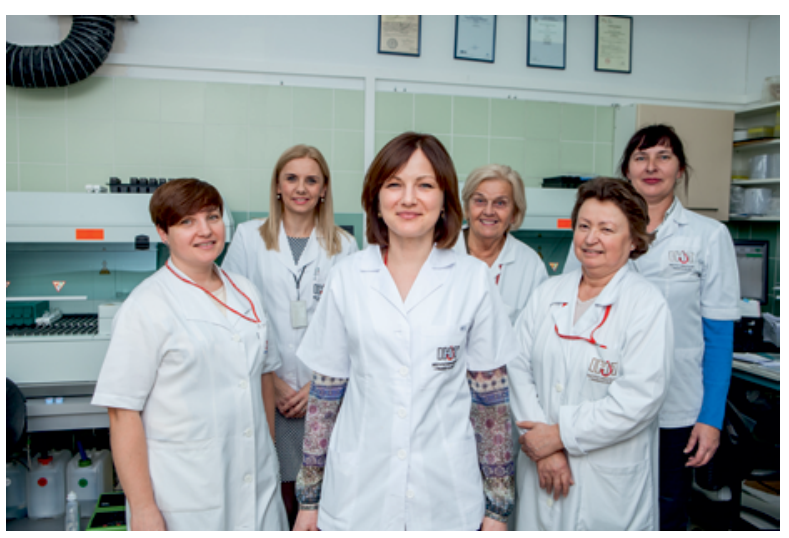

\section{Kierownik: mgr Beata Baran}

Adres: ul. Indiry Gandhi 14, 02-776 Warszawa tel.: $223496161 ; 223496548$

Badania wykonywane w Pracowni Hemostazy podano w poniższej tabeli.

\begin{tabular}{|c|c|c|c|}
\hline Nazwa badania & Metoda & Materiał & Wartości referencyjne \\
\hline $\begin{array}{l}\text { Oznaczenie czasu protrombinowego } \\
\text { (INR, wskaźnik protrombinowy) }\end{array}$ & $\begin{array}{l}\text { Koagulacyjna, pomiar czasu krzep- } \\
\text { nięcia z zastosowaniem aktywatora } \\
\text { szlaku zewnątrzpochodnego }\end{array}$ & Osocze cytrynianowe & $\begin{array}{l}\text { 9,0-13,5 s (INR: } \\
0,8-1,2 ; \text { wskaźnik } \\
\text { protrombinowy: } \\
80-120 \%)\end{array}$ \\
\hline Oznaczenie czasu trombinowego & $\begin{array}{l}\text { Koagulacyjna, pomiar czasu krzep- } \\
\text { nięcia z zastosowaniem aktywatora } \\
\text { — trombiny; wrażliwość na obec- } \\
\text { ność heparyny }\end{array}$ & Osocze cytrynianowe & $<21 \mathrm{~s}$ \\
\hline $\begin{array}{l}\text { Oznaczenie czasu batroksobinowego } \\
\text { (reptylazowego) }\end{array}$ & $\begin{array}{l}\text { Koagulacyjna, pomiar czasu krzep- } \\
\text { nięcia z zastosowaniem aktywatora } \\
\text { - enzymu reptylazy; niewrażliwy } \\
\text { na obecność heparyny }\end{array}$ & Osocze cytrynianowe & $<22 \mathrm{~s}$ \\
\hline $\begin{array}{l}\text { Oznaczenie fibrynogenu (metodą } \\
\text { Claussa) }\end{array}$ & Koagulacyjna, metoda Claussa & Osocze cytrynianowe & $2-5 \mathrm{~g} / \mathrm{l}$ \\
\hline D-dimery & Turbidymetryczna & Osocze cytrynianowe & $<550 \mathrm{ng} / \mathrm{ml}$ \\
\hline $\begin{array}{l}\text { Czas częściowej tromboplastyny } \\
\text { po aktywacji (APTT) }\end{array}$ & $\begin{array}{l}\text { Koagulacyjna, pomiar czasu krzep- } \\
\text { nięcia z zastosowaniem aktywatora } \\
\text { szlaku wewnątrzpochodnego }\end{array}$ & Osocze cytrynianowe & $25-33 \mathrm{~s}$ \\
\hline $\begin{array}{l}\text { Wykonanie testu korekcji APTT (testu } \\
\text { na obecność krążącego antykoagu- } \\
\text { lantu) }\end{array}$ & $\begin{array}{l}\text { Koagulacyjna, porównanie APTT } \\
\text { osocza badanego, wzorcowego } \\
\text { oraz mieszaniny osocza badanego } \\
\text { ze wzorcowym }\end{array}$ & Osocze cytrynianowe & $\begin{array}{l}\text { Korekcja prawidłowa } \\
\text { (test ujemny) }\end{array}$ \\
\hline $\begin{array}{l}\text { Oznaczenie aktywności czynnika II } \\
\text { (metodą koagulacyjną jednostop- } \\
\text { niową) }\end{array}$ & Koagulacyjna jednostopniowa & Osocze cytrynianowe & $70-120 \%$ \\
\hline $\begin{array}{l}\text { Oznaczenie aktywności czynnika V } \\
\text { (metodą koagulacyjną jednostop- } \\
\text { niową) }\end{array}$ & Koagulacyjna jednostopniowa & Osocze cytrynianowe & $70-120 \%$ \\
\hline $\begin{array}{l}\text { Oznaczenie aktywności czynnika VII } \\
\text { (metodą koagulacyjną jednostop- } \\
\text { niową) }\end{array}$ & Koagulacyjna jednostopniowa & Osocze cytrynianowe & $70-120 \%$ \\
\hline $\begin{array}{l}\text { Oznaczenie aktywności czynnika X (me- } \\
\text { todą koagulacyjną jednostopniową) }\end{array}$ & Koagulacyjna jednostopniowa & Osocze cytrynianowe & $70-120 \%$ \\
\hline $\begin{array}{l}\text { Ocena czasu lizy skrzepu euglobulin } \\
\text { (ELT) }\end{array}$ & $\begin{array}{l}\text { Pomiar czasu lizy skrzepu euglo- } \\
\text { bulin }\end{array}$ & Osocze cytrynianowe & $2-4 \mathrm{~h}$ \\
\hline $\begin{array}{l}\text { Test potwierdzenia obecności anty- } \\
\text { koagulantu toczniowego (w oparciu } \\
\text { o dRVVT) }\end{array}$ & $\begin{array}{l}\text { Koagulacyjna, z zastosowaniem } \\
\text { aktywatora - jadu żmii Russella } \\
\text { i nadmiaru fosfolipidów }\end{array}$ & Osocze cytrynianowe & $<1,2$ \\
\hline $\begin{array}{l}\text { Test potwierdzenia obecności anty- } \\
\text { koagulantu toczniowego (w oparciu } \\
\text { o APTT) }\end{array}$ & $\begin{array}{l}\text { Koagulacyjna, z zastosowaniem } \\
\text { aktywatora - krzemionki i fosfoli- } \\
\text { pidów heksagonalnych }\end{array}$ & Osocze cytrynianowe & Nie dotyczy \\
\hline
\end{tabular}




\begin{tabular}{|c|c|c|c|}
\hline Nazwa badania & Metoda & Materiał & Wartości referencyjne \\
\hline $\begin{array}{l}\text { Oznaczenie aktywności czynnika VIII } \\
\text { (metodą koagulacyjną jednostop- } \\
\text { niową) }\end{array}$ & Koagulacyjna jednostopniowa & Osocze cytrynianowe & $50-150 \%$ \\
\hline $\begin{array}{l}\text { Oznaczenie aktywności czynnika VIII } \\
\text { (metodą chromogenną) }\end{array}$ & Chromogenna & Osocze cytrynianowe & $60-150 \%$ \\
\hline $\begin{array}{l}\text { Oznaczenie miana inhibitora wobec } \\
\text { ludzkiego czynnika VIII }\end{array}$ & Bethesda w modyfikacji Nijmehen & Osocze cytrynianowe & $<0,5 \mathrm{jB} . / \mathrm{ml}$ \\
\hline $\begin{array}{l}\text { Oznaczenie antygenu czynnika } \\
\text { von Willebranda }\end{array}$ & Turbidymetryczna & Osocze cytrynianowe & $50-150 \%$ \\
\hline $\begin{array}{l}\text { Oznaczenie aktywności czynnika } \\
\text { von Willebranda (kofaktora rystocetyny) }\end{array}$ & $\begin{array}{l}\text { Oparta na aglutynacji płytek krwi } \\
\text { w obecności VWF i rystocetyny }\end{array}$ & Osocze cytrynianowe & $50-150 \%$ \\
\hline $\begin{array}{l}\text { Oznaczenie aktywności czynnika } \\
\text { von Willebranda (Siemens, Innovance } \\
\text { VWF } A c^{\circledR} \text { ) }\end{array}$ & $\begin{array}{l}\text { Turbidymetryczna; pomiar aktywno- } \\
\text { ści VWF bez stosowania rystocetyny }\end{array}$ & Osocze cytrynianowe & $50-150 \%$ \\
\hline $\begin{array}{l}\text { Wiązanie czynnika von Willebranda } \\
\text { z czynnikiem VIII (metodą ELISA) }\end{array}$ & ELISA & Osocze cytrynianowe & $>20 \%$ \\
\hline $\begin{array}{l}\text { Automatyczny pomiar czynności pły- } \\
\text { tek krwi PFA } 100 \text { CT: COL/EPI }\end{array}$ & $\begin{array}{l}\text { Czas krzepnięcia krwi pełnej podda- } \\
\text { nej aktywacji COL/EPI }\end{array}$ & Krew cytrynianowa & $62-100 \mathrm{~s}$ \\
\hline $\begin{array}{l}\text { Automatyczny pomiar czynności pły- } \\
\text { tek krwi PFA } 100 \text { CT: COL/ADP }\end{array}$ & $\begin{array}{l}\text { Czas krzepnięcia krwi pełnej podda- } \\
\text { nej aktywacji COL/ADP }\end{array}$ & Krew cytrynianowa & $82-150 \mathrm{~s}$ \\
\hline $\begin{array}{l}\text { Oznaczenie aktywności czynnika IX } \\
\text { (metodą koagulacyjną jednostop- } \\
\text { niową) }\end{array}$ & Koagulacyjna jednostopniowa & Osocze cytrynianowe & $50-150 \%$ \\
\hline $\begin{array}{l}\text { Oznaczenie miana inhibitora wobec } \\
\text { ludzkiego czynnika IX }\end{array}$ & Bethesda & Osocze cytrynianowe & $<0,5 \mathrm{jB} . / \mathrm{ml}$ \\
\hline $\begin{array}{l}\text { Oznaczenie aktywności czynnika XI } \\
\text { (metodą koagulacyjną jednostop- } \\
\text { niową) }\end{array}$ & Koagulacyjna jednostopniowa & Osocze cytrynianowe & $70-140 \%$ \\
\hline $\begin{array}{l}\text { Oznaczenie aktywności czynnika XII } \\
\text { (metodą koagulacyjną jednostop- } \\
\text { niową) }\end{array}$ & Koagulacyjna jednostopniowa & Osocze cytrynianowe & $70-140 \%$ \\
\hline $\begin{array}{l}\text { Ocena rozpuszczalności skrzepu w 5M } \\
\text { roztworze mocznika (czynnik XIII) }\end{array}$ & Metoda jakościowa & Osocze cytrynianowe & Obecny czynnik XIII \\
\hline $\begin{array}{l}\text { Oznaczenie aktywności czynnika XIII } \\
\text { (metodą chromogenną) }\end{array}$ & Chromogenna & Osocze cytrynianowe & $70-140 \%$ \\
\hline $\begin{array}{l}\text { Oznaczenie aktywności antytrombiny } \\
\text { (anty Ila) }\end{array}$ & $\begin{array}{l}\text { Chromogenna; substrat antytrom- } \\
\text { biny - aktywny czynnik II (Ila) }\end{array}$ & Osocze cytrynianowe & $79-112 \%$ \\
\hline $\begin{array}{l}\text { Oznaczenie aktywności antytrombiny } \\
\text { (anty Xa) }\end{array}$ & $\begin{array}{l}\text { Chromogenna; substrat antytrom- } \\
\text { biny - aktywny czynnik X (Xa) }\end{array}$ & Osocze cytrynianowe & $83-118 \%$ \\
\hline $\begin{array}{l}\text { Oznaczenie antygenu antytrombiny } \\
\text { (metodą immunodyfuzji radialnej) }\end{array}$ & Immunodyfuzji radialnej & Osocze cytrynianowe & $73-130 \%$ \\
\hline $\begin{array}{l}\text { Oznaczenie aktywności białka C (me- } \\
\text { todą chromogenną) }\end{array}$ & Chromogenna & Osocze cytrynianowe & $70-140 \%$ \\
\hline Oznaczenie antygenu białka C & ELISA & Osocze cytrynianowe & $70-140 \%$ \\
\hline $\begin{array}{l}\text { Oznaczenie antygenu wolnego biał- } \\
\text { ka S }\end{array}$ & Metoda turbidymetryczna & Osocze cytrynianowe & $\begin{array}{l}\text { Kobiety: } 60,1- \\
-113,6 \% * * * ; \\
\text { mężczyźni: } 67,5-139 \%\end{array}$ \\
\hline $\begin{array}{l}\text { Oznaczenie aktywności białka S (me- } \\
\text { todą koagulacyjną) }\end{array}$ & Koagulacyjna & Osocze cytrynianowe & $\begin{array}{l}59-118 \% \text { - kobiety } \\
\text { niestosujące doust- } \\
\text { nych leków antykon- } \\
\text { cepcyjnych; } 52-118 \% \\
\text { - kobiety stosujące } \\
\text { doustne leki antykon- } \\
\text { cepcyjne; mężczyźni: } \\
75 \% \text { do > } 130 \%\end{array}$ \\
\hline
\end{tabular}




\begin{tabular}{|c|c|c|c|}
\hline Nazwa badania & Metoda & Materiał & Wartości referencyjne \\
\hline $\begin{array}{l}\text { Ocena oporności na aktywowane } \\
\text { białko C (test APCR) }\end{array}$ & $\begin{array}{l}\text { Koagulacyjna, z zastosowaniem } \\
\text { osocza deficytowego - pozbawio- } \\
\text { nego czynnika } V\end{array}$ & Osocze cytrynianowe & $0,7-1,2$ \\
\hline $\begin{array}{l}\text { Oznaczenie miana przeciwciał anty- } \\
\text { kardiolipinowych w klasie IgG }\end{array}$ & $\begin{array}{l}\text { Oparta na ELISA w tzw. zamknię- } \\
\text { tym systemie paskowym, kalibracja } \\
\text { wg Harisa }\end{array}$ & Surowica & $<10$ \\
\hline $\begin{array}{l}\text { Oznaczenie miana przeciwciał anty- } \\
\text { kardiolipinowych w klasie IgM }\end{array}$ & $\begin{array}{l}\text { Oparta na ELISA w tzw. zamknię- } \\
\text { tym systemie paskowym, kalibracja } \\
\text { wg Harisa }\end{array}$ & Surowica & $<7$ \\
\hline $\begin{array}{l}\text { Oznaczenie przeciwciał przeciw } \\
\beta_{2} \text {-glikoproteinie I w klasie IgG }\end{array}$ & $\begin{array}{l}\text { Oparta na ELISA w tzw. zamknię- } \\
\text { tym systemie paskowym, kalibracja } \\
\text { wg Harisa }\end{array}$ & Surowica & $<5$ \\
\hline $\begin{array}{l}\text { Oznaczenie przeciwciał przeciw } \\
\beta_{2} \text {-glikoproteinie I w klasie IgM }\end{array}$ & $\begin{array}{l}\text { Oparta na ELISA w tzw. zamknię- } \\
\text { tym systemie paskowym, kalibracja } \\
\text { wg Harisa }\end{array}$ & Surowica & $<5$ \\
\hline $\begin{array}{l}\text { Oznaczenie aktywności heparyny } \\
\text { w osoczu (anty-Xa) }\end{array}$ & $\begin{array}{l}\text { Chromogenna, układ testowy } \\
\text { z nadmiarem egzogennej antytrom- } \\
\text { biny }\end{array}$ & Osocze cytrynianowe & $\begin{array}{l}\text { Przedział dla tera- } \\
\text { peutycznych dawek } \\
\text { heparyn drobnoczą- } \\
\text { steczkowych: 0,6-1,2 } \\
\text { j. anty-Xa/ml }\end{array}$ \\
\hline $\begin{array}{l}\text { Oznaczenie stężenia riwaroksabanu } \\
\text { w osoczu (anty-Xa; ng/ml) }\end{array}$ & Chromogenna & Osocze cytrynianowe & Nie dotyczy \\
\hline $\begin{array}{l}\text { Ocena stopnia generacji Trombiny } \\
\left.\text { (TGA, Technoclone }{ }^{\circledR}\right)\end{array}$ & Fluorogenna & Osocze cytrynianowe & Nie dotyczy \\
\hline $\begin{array}{l}\text { Badanie tromboelastometryczne } \\
\text { ROTEM Delta na-TEM }\end{array}$ & Test globalny, natywny & Krew cytrynianowa & $\begin{array}{l}\text { Czas okluzji } \\
\text { (CT, closure time) }\end{array}$ \\
\hline $\begin{array}{l}\text { Badanie tromboelastometryczne } \\
\text { ROTEM Delta in-TEM }\end{array}$ & $\begin{array}{l}\text { Test globalny z zastosowaniem } \\
\text { aktywatora szlaku wewnątrzpo- } \\
\text { chodnego }\end{array}$ & Krew cytrynianowa & $\begin{array}{l}\text { Czas krzepnięcia: } \\
\text { 100-240 s; CFT (czas } \\
\text { tworzenia się skrzepu): } \\
30-110 \mathrm{~s} ; \alpha \text { (kąt alfa): } \\
\text { 70-83; MCF (maksy- } \\
\text { malna spójność skrze- } \\
\text { pu): } 50-72 \mathrm{~mm}\end{array}$ \\
\hline $\begin{array}{l}\text { Badanie tromboelastometryczne } \\
\text { ROTEM Delta ex-TEM }\end{array}$ & $\begin{array}{l}\text { Test globalny z zastosowaniem ak- } \\
\text { tywatora szlaku zewnątrzpochod- } \\
\text { nego }\end{array}$ & Krew cytrynianowa & $\begin{array}{l}\text { Czas krzepnięcia: } \\
\text { 38-79 s; CFT (czas } \\
\text { tworzenia się skrzepu): } \\
\text { 34-159 s; } \alpha \text { (kąt alfa): } \\
63-83^{\circ} ; \text { MCF (maksy- } \\
\text { malna spójność skrze- } \\
\text { pu): 50-72 mm }\end{array}$ \\
\hline $\begin{array}{l}\text { Badanie tromboelastometryczne } \\
\text { ROTEM Delta fib-TEM }\end{array}$ & $\begin{array}{l}\text { Test globalny z zastosowaniem ak- } \\
\text { tywatora szlaku zewnątrzpochod- } \\
\text { nego oraz inhibitora płytek krwi }\end{array}$ & Krew cytrynianowa & $\begin{array}{l}\text { MCF (maksymalna } \\
\text { spójność skrzepu): } \\
\text { 9-25 mm; ocena } \\
\text { w porównaniu } \\
\text { z testem ex-TEM }\end{array}$ \\
\hline $\begin{array}{l}\text { Badanie tromboelastometryczne } \\
\text { ROTEM Delta ap-TEM }\end{array}$ & $\begin{array}{l}\text { Test globalny z zastosowaniem ak- } \\
\text { tywatora szlaku zewnątrzpochod- } \\
\text { nego oraz inhibitora heparyny }\end{array}$ & Krew cytrynianowa & $\begin{array}{l}\text { Ocena w porównaniu } \\
\text { z testem ex-TEM }\end{array}$ \\
\hline $\begin{array}{l}\text { Oznaczenie fibrynogenu (metodą } \\
\text { kolorymetryczną) }\end{array}$ & Kolorymetryczna & Osocze cytrynianowe & $2-5 \mathrm{~g} / \mathrm{l}$ \\
\hline $\begin{array}{l}\text { Oznaczenie białka całkowitego } \\
\text { w osoczu i preparatach osoczopo- } \\
\text { chodnych (metodą kolorymetryczną) }\end{array}$ & Kolorymetryczna & Osocze cytrynianowe & Nie dotyczy \\
\hline $\begin{array}{l}\text { Wykrywanie inwersji w intronie } 22 \\
\text { (INV22) genu F8 }\end{array}$ & Inverse-Shifting PCR (IS-PCR)** & Krew EDTA & Nie dotyczy \\
\hline $\begin{array}{l}\text { Wykrywanie inwersji w intronie } 22 \\
\text { (INV22) genu F8 (badanie nosiciel- } \\
\text { stwa) }\end{array}$ & Inverse-Shifting PCR (IS-PCR)** & Krew EDTA & Nie dotyczy \\
\hline
\end{tabular}


Hematologia 2016, tom 7, suplement A

\begin{tabular}{|c|c|c|c|}
\hline Nazwa badania & Metoda & Materiał & Wartości referencyjne \\
\hline $\begin{array}{l}\text { Wykrywanie inwersji w intronie } 1 \\
\text { (INV1) genu F8 }\end{array}$ & Inverse-Shifting PCR (IS-PCR)** & Krew EDTA & Nie dotyczy \\
\hline $\begin{array}{l}\text { Analiza sekwencji wszystkich ekso- } \\
\text { nów genu F8 }\end{array}$ & Sekwencjonowanie DNA & Krew EDTA & Nie dotyczy \\
\hline Analiza sekwencji eksonu 14 genu F8 & Sekwencjonowanie DNA & Krew EDTA & Nie dotyczy \\
\hline $\begin{array}{l}\text { Analiza sekwencji eksonów 1-13 } \\
\text { oraz 15-26 genu F8 }\end{array}$ & sekwencjonowanie DNA & Krew EDTA & Nie dotyczy \\
\hline $\begin{array}{l}\text { Analiza sekwencji wybranego ekso- } \\
\text { nu/mutacji genu F8 }\end{array}$ & Sekwencjonowanie DNA & Krew EDTA & Nie dotyczy \\
\hline $\begin{array}{l}\text { Analiza sekwencji wszystkich ekso- } \\
\text { nów genu F9 }\end{array}$ & Sekwencjonowanie DNA & Krew EDTA & Nie dotyczy \\
\hline $\begin{array}{l}\text { Analiza sekwencji wybranego ekso- } \\
\text { nu/mutacji genu F9 }\end{array}$ & Sekwencjonowanie DNA & Krew EDTA & Nie dotyczy \\
\hline $\begin{array}{l}\text { Analiza sekwencji promotora i ekso- } \\
\text { nu } 1 \text { genu F9 (typu Leyden) }\end{array}$ & Sekwencjonowanie DNA & Krew EDTA & Nie dotyczy \\
\hline $\begin{array}{l}\text { Analiza sekwencji eksonu } 2 \text { genu F9 } \\
\text { (wykrywanie mutacji p.Ala37Thr lub } \\
\text { p.Ala37Val - nadwrażliwość na VKA) }\end{array}$ & Sekwencjonowanie DNA & Krew EDTA & Nie dotyczy \\
\hline $\begin{array}{l}\text { Analiza sekwencji eksonów 17-27 } \\
\text { genu VWF (typu 2N) }\end{array}$ & Sekwencjonowanie DNA & Krew EDTA & Nie dotyczy \\
\hline $\begin{array}{l}\text { Analiza sekwencji eksonu } 28 \\
\text { genu } V W F \text { (typu 2B/2A/2M) }\end{array}$ & Sekwencjonowanie DNA & Krew EDTA & Nie dotyczy \\
\hline $\begin{array}{l}\text { Analiza sekwencji eksonów 18-28 } \\
\text { genu VWF (typu 1) }\end{array}$ & Sekwencjonowanie DNA & Krew EDTA & Nie dotyczy \\
\hline $\begin{array}{l}\text { Analiza sekwencji wybranego ekso- } \\
\text { nu/mutacji genu VWF }\end{array}$ & Sekwencjonowanie DNA & Krew EDTA & Nie dotyczy \\
\hline $\begin{array}{l}\text { Analiza sekwencji wszystkich ekso- } \\
\text { nów genu F11 }\end{array}$ & Sekwencjonowanie DNA & Krew EDTA & Nie dotyczy \\
\hline $\begin{array}{l}\text { Analiza sekwencji wybranego ekso- } \\
\text { nu/mutacji genu F11 }\end{array}$ & Sekwencjonowanie DNA & Krew EDTA & Nie dotyczy \\
\hline $\begin{array}{l}\text { Analiza sekwencji wszystkich ekso- } \\
\text { nów genu SERPINC1 (niedobór anty- } \\
\text { trombiny) }\end{array}$ & Sekwencjonowanie DNA & Krew EDTA & Nie dotyczy \\
\hline $\begin{array}{l}\text { Analiza sekwencji wybranego ekso- } \\
\text { nu/mutacji genu SERPINC1 (niedobór } \\
\text { antytrombiny) }\end{array}$ & Sekwencjonowanie DNA & Krew EDTA & Nie dotyczy \\
\hline
\end{tabular}

*Wartości referencyjne mogą ulec zmianie; **modyfikacja za: Rossetti i wsp. J. Thromb. Haemost. 2008; 6950: 830-836; ***norma dotyczy kobiet niestosujących doustnej antykoncepcji ani hormonalnej terapii zastępczej oraz niebędących w ciąży 


\section{Pracownia Choroby von Willebranda}

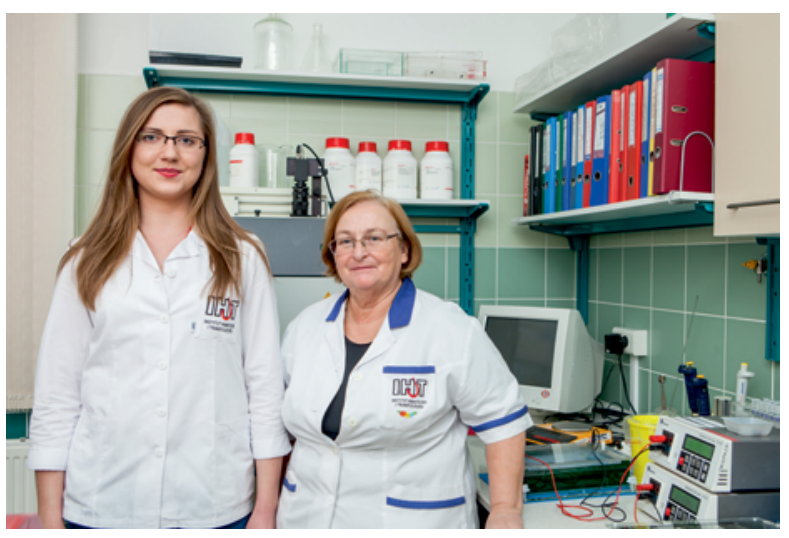

Kierownik: prof. dr hab. n. med. Ksenia Bykowska Adres: ul. Indiry Gandhi 14, 02-776 Warszawa tel.: 223496 160; 223496543

Do zakresu badań wykonywanych w Pracowni Choroby von Willebranda należą:

1) badania biochemiczne/immunoenzymatyczne;

\begin{tabular}{|c|c|c|c|}
\hline Nazwa badania & Metoda & Materiał & Wartości referencyjne \\
\hline $\begin{array}{l}\text { Oznaczenie aktywności } \\
\text { ADAMTS13 }\end{array}$ & Chromogenna & Osocze cytrynianowe & $40-130 \%$ \\
\hline $\begin{array}{l}\text { Oznaczenie inhibitora } \\
\text { ADAMTS13 }\end{array}$ & Chromogenna & Osocze cytrynianowe & $\begin{array}{l}\text { Wartości: } \\
\text { - ujemne }<12 \mathrm{j} . / \mathrm{ml} \\
\text { - dodatnie }>15 \mathrm{j} . / \mathrm{ml} \\
\text { - graniczne } 12-15 \mathrm{j} . / \mathrm{ml}\end{array}$ \\
\hline Aktywność ADAMTS13 & Chromogenna & Osocze cytrynianowe & $40-130 \%$ \\
\hline $\begin{array}{l}\text { Oznaczenie inhibitora } \\
\text { ADAMTS13 }\end{array}$ & Chromogenna & Osocze cytrynianowe & $\begin{array}{l}\text { Wartości: } \\
\text { - ujemne }<12 \mathrm{j} . / \mathrm{ml} \\
\text { - dodatnie }>15 \mathrm{j} . / \mathrm{ml} \\
\text { - graniczne } 12-15 \mathrm{j} . / \mathrm{ml}\end{array}$ \\
\hline $\begin{array}{l}\text { Analiza multimerów czyn- } \\
\text { nika von Willebranda }\end{array}$ & Chemiluminescencyjna & Osocze cytrynianowe & $\begin{array}{l}\text { - Obecność wszystkich frakcji mul- } \\
\text { timetrów, prawidłowe stężenie - } \\
\text { dawca, 2M vWD } \\
\text { - Brak frakcji wysokocząsteczkowych } \\
\text { vWF - 2A i 2B vWD }\end{array}$ \\
\hline
\end{tabular}

2) badania agregometryczne/funkcji płytek krwi

\begin{tabular}{|c|c|c|c|}
\hline Nazwa badania & Metoda & Materiał & Wartości referencyjne \\
\hline Agregacja płytek krwi & $\begin{array}{l}\text { Ocena agregacji płytek } \\
\text { krwi pod wpływem niskich } \\
\text { stężeń rystocetyny }(0,5-0,7 \\
\mathrm{mg} / \mathrm{ml})\end{array}$ & \multirow{3}{*}{$\begin{array}{l}\text { Osocze cytrynianowe: } \\
\text { ubogopłytkowe (PPP) } \\
\text { i bogatopłytkowe (PRP) }\end{array}$} & $\begin{array}{l}\text { Zwiększone > 30\% powinowa- } \\
\text { ctwo czynnika von Willebranda } \\
\text { do płytek krwi } \\
\text { - }<10 \% \text { - wartości prawidłowe }\end{array}$ \\
\hline $\begin{array}{l}\text { Badanie funkcji płytek krwi } \\
\text { (ADP, kolagen, rystocetyna, } \\
\text { kwas arachidonowy) }\end{array}$ & $\begin{array}{l}\text { Ocena agregacji płytek } \\
\text { krwi pod wpływem róż- } \\
\text { nych agonistów: ADP, ko- } \\
\text { lagenu, rystocetyny, kwasu } \\
\text { acetylosalicylowego, kwasu } \\
\text { arachidonowego }\end{array}$ & & $\begin{array}{l}\text { - } \mathrm{ADP}-69-88 \% \text {, epinefryna - } \\
68-88 \% \\
\text { - Z kwasem arachidonowym - 74- } \\
\text {-99\%, kolagenem }-70-90 \% \text {, } \\
\text { rystocetyną 1,25 mg/ml }-70-90 \%\end{array}$ \\
\hline $\begin{array}{l}\text { Badanie funkcji płytek krwi } \\
\text { (ADP, kolagen, rystocetyna, } \\
\text { kwas acetylosalicylowy, } \\
\text { kwas arachidonowy) i test } \\
\text { RIPA }\end{array}$ & $\begin{array}{l}\text { Ocena agregacji płytek krwi } \\
\text { pod wpływem różnych } \\
\text { agonistów: ADP, kolagenu, } \\
\text { rystocetyny } 1,25 \mathrm{mg} / \mathrm{ml} \text {, } \\
\text { kwas arachidonowego i ry- } \\
\text { stocetyny } 0,5-0,7 \mathrm{mg} / \mathrm{ml}\end{array}$ & & $\begin{array}{l}\text { - ADP - 69-88\%, epinefryna - } \\
\text { 68-88\% } \\
\text { - Z kwasem arachidonowym - } \\
\text { 74-99\%, kolagenem - 70-90\%, } \\
\text { rystocetyną 1,25 } \mathrm{mg} / \mathrm{ml}-70-90 \%\end{array}$ \\
\hline
\end{tabular}


3) badania genetyczne $-z$ krwi obwodowej pobranej na EDTA, manualną metodą kolumienkową, izoluje się DNA. Do identyfikacji wybranych prozakrzepowych mutacji punktowych wykorzystuje się metodę PCR w połączeniu $z$ analizą polimorfizmu długości fragmentów restrykcyjnych (PCR-RFLP). Wykonywane badania podano w poniższej tabeli.

\begin{tabular}{|l|l|l|l|}
\hline Nazwa badania & Metoda & Materiał & Wartości referencyjne \\
\hline $\begin{array}{l}\text { Wykrywanie mutacji typu } \\
\text { Leiden genu czynnika V }\end{array}$ & PCR-RFLP & Krew EDTA & $\begin{array}{l}\text { - Homozygota: 130bp, 157bp - wynik dodatni (homo) } \\
\text { Heterozygota: 93bp, 130bp, 157bp - wynik dodatni } \\
\text { (het) }\end{array}$ \\
\hline $\begin{array}{l}\text { Wykrywanie mutacji genu } \\
\text { protrombiny G20210A }\end{array}$ & PCR-RFLP & Krew EDTA & $\begin{array}{l}\text { - Homozygota: 322bp - wynik dodatni (homo) } \\
\text { - Heterozygota: 345bp, 322bp, 23bp - wynik dodatni } \\
\text { (het) }\end{array}$ \\
\hline $\begin{array}{l}\text { Wykrywanie mutacji genu } \\
\text { MTHFR C677T }\end{array}$ & PCR-RFLP & Krew EDTA & $\begin{array}{l}\text { - Howidłowy: } 345 \text { bp (mutacja nieobecna) } \\
\text { - Heterozygota: } 198 \mathrm{bp}, 175 \mathrm{bp}-\text { wynik dodatni (het) }\end{array}$ \\
\hline
\end{tabular}

\section{Pracownia Porfirii}

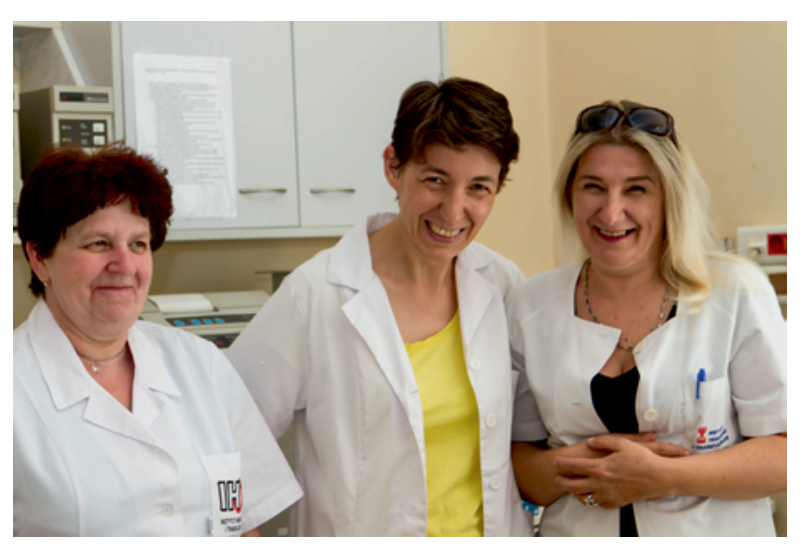

Kierownik: dr n. med. Agnieszka Lipniacka Adres: ul. Chocimska 5, budynek B, 00-791 Warszawa tel.: $223496617 ; 223496635$

Do zadań Pracowni należą: diagnostyka pacjentów $z$ podejrzeniem zaostrzenia lub ataku porfirii, diagnostyka pacjentów $z$ potwierdzoną porfirią w celu określenia jej rodzaju, diagnostyka członków rodziny pacjentów $\mathrm{z}$ porfirią $\mathrm{w}$ celu ustalenia nosicieli defektywnego genu, badania kontrolne pacjentów $z$ porfirią, wydawanie pacjentom $z$ jawną i utajoną postacią porfirii Kart Chorego na Porfirię oraz listy leków bezpiecznych w porfirii, rejestracja pacjentów w bazie danych Pracowni, prowadzenie badań naukowych $z$ zakresu porfirii, szkolenia $z$ zakresu porfirii wszystkich osób zainteresowanych tą tematyką, współpraca $z$ innymi ośrodkami zajmującymi się porfirią w Europie, współpraca $z$ innymi komórkami organizacyjnymi Instytutu w zakresie ich działalności naukowej i usługowo-badawczej.

Badania wykonywane w Pracowni Porfirii podano w poniższej tabeli.

\begin{tabular}{|c|c|}
\hline Rodzaj badania & Materiał \\
\hline $\begin{array}{l}\text { Prekursory porfiryn metodą chromatogra- } \\
\text { fii jonowymiennej }\end{array}$ & \multirow[t]{2}{*}{ Mocz } \\
\hline $\begin{array}{l}\text { Porfiryny i izomery porfiryn metodą wyso- } \\
\text { kociśnieniowej chromatografii cieczowej } \\
\text { (HPLC) }\end{array}$ & \\
\hline Izomery porfiryn metodą HPLC & Kat \\
\hline $\begin{array}{l}\text { - Widmo fluorescencji porfiryn w osoczu } \\
\text { i erytrocytach } \\
\text { - Protoporfiryna wolna i cynkowa w ery- } \\
\text { trocytach metodą HPLC } \\
\text { - Izomery porfiryn w osoczu metodą } \\
\text { HPLC } \\
\text { - Aktywność enzymów biosyntezy hemu } \\
\text { - Badania genetyczne }\end{array}$ & Krew \\
\hline
\end{tabular}




\section{ZAKŁAD IMMUNOLOGII HEMATOLOGICZNEJ I TRANSFUZJOLOGICZNEJ}

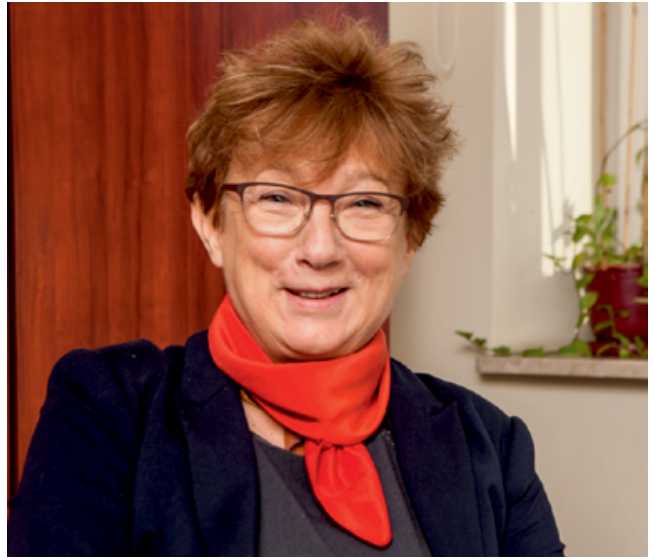

Kierownik: prof. dr hab. n. med. Ewa Brojer

Konsultant: prof. dr hab. n. med. Krystyna Maślanka Adiunkci: dr n. przyr. Katarzyna Guz, dr n. przyr. Agnieszka Orzińska, dr n. med. Małgorzata Uhrynowska Diagności laboratoryjni: mgr Pamela Bartoszewicz, mgr Justyna Bednarz, mgr Ewa Gołaszewska, mgr Edyta Klimczak-Jajor, mgr Patrycja Łopacz, mgr Hanna Łopieńska, mgr Anna Myślińska, mgr Maria Nowaczek-Migas, mgr Agnieszka Kowalska, mgr Justyna Pastuszka, mgr Anna Kiszło, mgr Monika Pelc-Kłopotowska, mgr Hanna Pyl, mgr Joanna Skulimowska, mgr Justyna Spychalska, mgr Agnieszka Gierszon, inż. tech. Jadwiga Sak-Budzisz, mgr Ewelina Sokół, mgr Magdalena Piłat

Biolodzy: mgr Anna Główka, mgr Magdalena Krzemieniowska, mgr Katarzyna Kuziora, mgr Magdalena Michalik, mgr Justyna Smolarczyk-Wodzińska Technicy: st. tech. Ewa Dudnikow, st. tech. Beata Sierocka, st. tech. Halina Nasiegniewska, tech. Anna Plizak Pomoc laboratoryjna: Małgorzata Tratkiewicz Sekretariat: Katarzyna Stachurska

Zakład prowadzi działalność diagnostyczną, naukową, dydaktyczną i ekspercką w zakresie immunologii hematologicznej i transfuzjologicznej. Celem jest opracowywanie i wdrażanie metod badawczych zapewniających bezpieczne przetaczanie krwi i jej składników, nowoczesnych metod diagnostyki allo- i autoimmunizacji antygenami komórek krwi, wrodzonych i nabytych anemii hemolitycznych i badań chimeryzmu. Do głównych zadań Zakładu należy również nadzór merytoryczny nad badaniami $\mathrm{w}$ dziedzinie immunologii transfuzjologicznej prowa-

Adres: ul. Chocimska 5, 00-791 Warszawa tel.: 223496 663; 605267600

faks 223496611

e-mail: sekimmunologia@ihit.waw.pl

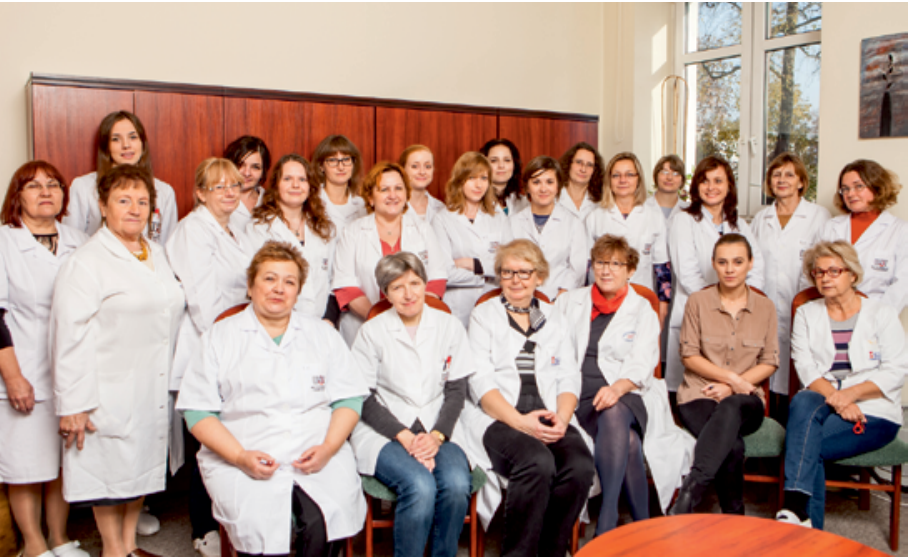

dzonymi w jednostkach organizacyjnych publicznej służby krwi. Zakład prowadzi programy oceny jakości i audytuje laboratoria funkcjonujące w CKiK i w szpitalach, które zajmują się badaniami przedtransfuzyjnymi i badaniami w zakresie konfliktów matczyno-płodowych. W ramach umowy $z$ Polskim Centrum Badań i Certyfikacji w Zakładzie wykonuje się badania odczynników do diagnostyki in vitro z zakresu immunologii transfuzjologicznej oraz wydaje opinie dopuszczające je do stosowania. W Zakładzie wykonuje się również badania i ekspertyzy dotyczące aparatury.

Wszystkie pracownie Zakładu biorą udział w międzynarodowych programach zewnętrznej kontroli jakości (UQ NEQAS, INSTAND e.V., ISBT).

Naukowe zainteresowania zespołu Zakładu wiążą się $z$ profilem prowadzonej działalności diagnostycznej i eksperckiej i dotyczą immunologii krwinek czerwonych, płytek krwi i granulocytów, immunopatologii ciąży, badania chimeryzmu po przeszczepieniu krwiotwórczych komórek macierzystych i diagnostyki wrodzonych i nabytych niedokrwistości hemolitycznych oraz dyserytropoetycznych.

Zakład prowadzi liczne szkolenia, kursy i wykłady dla diagnostów specjalizujących się w laboratoryjnej transfuzjologii medycznej, dla lekarzy specjalizujących się $\mathrm{w}$ hematologii i transfuzjologii klinicznej oraz dla lekarzy ginekologów, położników i neonatologów.

W skład Zakładu wchodzą: Pracownia Immunologii Krwinek Czerwonych, Pracownia Immunologii Leukocytów i Płytek Krwi, Pracownia Immunopatologii Ciąży, Pracownia Niedokrwistości Uwarunkowanych Genetycznie, Pracownia Grup Krwi i Prób Zgodności oraz Pracownia Genetyki Komórek Krwi i Chimeryzmu. 


\section{Pracownia Immunologii Krwinek Czerwonych}

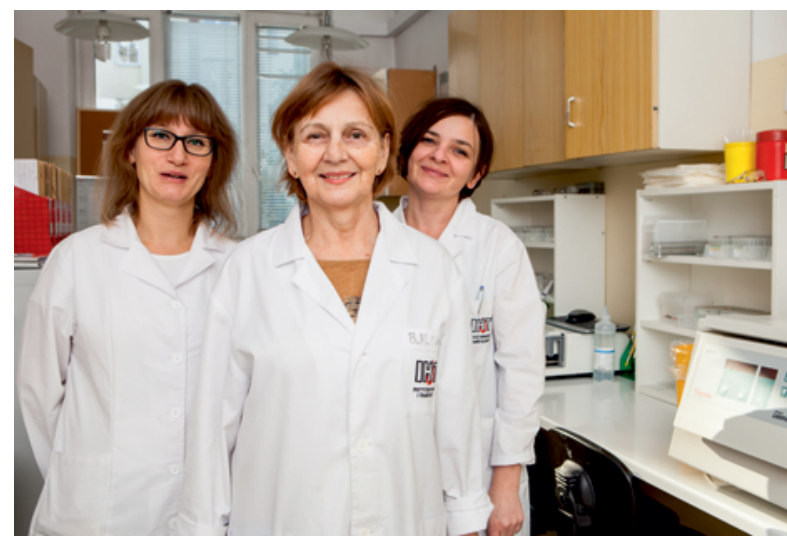

Kierownik: mgr Monika Pelc-Kłopotowska

Zespół: mgr Justyna Bednarz, mgr Hanna Łopieńska, mgr Agnieszka Kowalska

Adres: ul. Chocimska 5, 00-791 Warszawa

tel.: 223496 669; 223496651

e-mail: mpelc@ihit.waw.pl

W Pracowni jest wykonywany pełen zakres diagnostyki $\mathrm{w}$ dziedzinie immunologii transfu- zjologicznej, w tym badania konsultacyjne w laboratoriach CKiK w przypadkach zaistnienia trudności w określeniu swoistości przeciwciał występujących u chorych i kobiet w ciąży. Badania sa prowadzone $z$ wykorzystaniem zasobów banku próbek krwinek o rzadkich antygenach i próbek osocza $z$ przeciwciałami o unikatowych swoistościach (SCARF). Jednocześnie, dzięki dostępowi do międzynarodowych baz danych o dawcach o unikatowych antygenach, Pracownia służy informacjami o dostępności krwi do przetoczenia. W Pracowni prowadzi się badania diagnostyczne w niedokrwistościach autoimmunohemolitycznych, diagnostykę serologiczną słabych odmian antygenów, szczególnie w układach $\mathrm{ABO}$ i Rh, a także diagnostykę hemolitycznych odczynów poprzetoczeniowych.

Do zakresu badań wykonywanych w Pracowni Immunologii Krwinek Czerwonych należą:

1) badania serologiczne w kierunku niedokrwistości autoimmunohemolitycznych/alloimmunohemolitycznych po przetoczeniu składników krwi

\begin{tabular}{|l|l|l|l|}
\hline Rodzaj badania & Metoda & Materiał* & Wartości referencyjne \\
\hline $\begin{array}{l}\text { Diagnostyka NAIH typu ciep- } \\
\text { łego }\end{array}$ & $\begin{array}{l}\text { Techniki mikrokolumnowa } \\
\text { i probówkowa }\end{array}$ & $\begin{array}{l}\text { Krew na skrzep } 5 \mathrm{ml} \\
\text { Krew pełna (EDTA) } 5 \mathrm{ml}\end{array}$ & $\begin{array}{l}\text { Aglutynacja krwinek/brak } \\
\text { aglutynacji }\end{array}$ \\
\hline $\begin{array}{l}\text { Diagnostyka NAIH typu zim- } \\
\text { nego }\end{array}$ & $\begin{array}{l}\text { Techniki mikrokolumnowa } \\
\text { i probówkowa }\end{array}$ & $\begin{array}{l}\text { Krew na skrzep } 5 \mathrm{ml} \\
\text { Krew pełna(EDTA) } 5 \mathrm{ml}\end{array}$ & $\begin{array}{l}\text { Aglutynacja krwinek/brak } \\
\text { aglutynacji }\end{array}$ \\
\hline $\begin{array}{l}\text { Diagnostyka NAIH typu mie- } \\
\text { szanego }\end{array}$ & $\begin{array}{l}\text { Techniki mikrokolumnowa } \\
\text { i probówkowa }\end{array}$ & $\begin{array}{l}\text { Krew na skrzep } 5 \mathrm{ml} \\
\text { Krew pełna(EDTA) } 5 \mathrm{ml}\end{array}$ & $\begin{array}{l}\text { Aglutynacja krwinek/brak } \\
\text { aglutynacji }\end{array}$ \\
\hline $\begin{array}{l}\text { Diagnostyka napadowej zim- } \\
\text { nej hemoglobinurii }\end{array}$ & $\begin{array}{l}\text { Techniki mikrokolumnowa } \\
\text { i probówkowa }\end{array}$ & Krew na skrzep $5 \mathrm{ml}$ & $\begin{array}{l}\text { Aglutynacja krwinek/brak } \\
\text { aglutynacji }\end{array}$ \\
\hline $\begin{array}{l}\text { Analiza serologiczna powikła- } \\
\text { nia poprzetoczeniowego }\end{array}$ & $\begin{array}{l}\text { Techniki mikrokolumnowa } \\
\text { i probówkowa }\end{array}$ & $\begin{array}{l}\text { Krew na skrzep } 5 \mathrm{ml} \\
\text { Krew pełna (EDTA) } 5 \mathrm{ml}\end{array}$ & $\begin{array}{l}\text { Aglutynacja krwinek/brak } \\
\text { aglutynacji }\end{array}$ \\
\hline
\end{tabular}

*U dzieci ilość pobranego materiału w zależności od wieku

2) badania serologiczne u biorców przed przeszczepieniem i po przeszczepieniu HSC

\begin{tabular}{|l|l|l|l|}
\hline Rodzaj badania & Metoda & Materiał* & Wartości referencyjne \\
\hline $\begin{array}{l}\text { Badanie serologiczne u pa- } \\
\text { cjenta przed przeszczepie- } \\
\text { niem HSC }\end{array}$ & $\begin{array}{l}\text { Techniki mikrokolumnowa } \\
\text { i probówkowa }\end{array}$ & $\begin{array}{l}\text { Krew na skrzep } 5 \mathrm{ml} \\
\text { Krew pełna (EDTA) } 5 \mathrm{ml}\end{array}$ & $\begin{array}{l}\text { Aglutynacja krwinek/brak } \\
\text { aglutynacji }\end{array}$ \\
\hline $\begin{array}{l}\text { Badanie serologiczne u pa- } \\
\text { cjenta po przeszczepieniu } \\
\text { HSC }\end{array}$ & $\begin{array}{l}\text { Techniki mikrokolumnowa } \\
\text { i probówkowa }\end{array}$ & $\begin{array}{l}\text { Krew na skrzep } 5 \mathrm{ml} \\
\text { Krew pełna (EDTA) } 5 \mathrm{ml}\end{array}$ & $\begin{array}{l}\text { Aglutynacja krwinek/brak } \\
\text { aglutynacji }\end{array}$ \\
\hline $\begin{array}{l}\text { Badanie serologiczne u daw- } \\
\text { cy HSC }\end{array}$ & $\begin{array}{l}\text { Techniki mikrokolumnowa } \\
\text { i probówkowa }\end{array}$ & Krew pełna (EDTA) $5 \mathrm{ml}$ & $\begin{array}{l}\text { Aglutynacja krwinek/brak } \\
\text { aglutynacji }\end{array}$ \\
\hline $\begin{array}{l}\text { Określanie miana anty- } \\
\text {-A lub/i anty-B klas lgM i lgG }\end{array}$ & Technika mikrokolumnowa & $\begin{array}{l}\text { Krew na skrzep } 5 \mathrm{ml} \text { lub } \\
\text { krew pełna (EDTA) } 5 \mathrm{ml}\end{array}$ & $\begin{array}{l}\text { Aglutynacja krwinek/brak } \\
\text { aglutynacji }\end{array}$ \\
\hline
\end{tabular}

*U dzieci ilość pobranego materiału w zależności od wieku 
3) identyfikacja alloprzeciwciał do krwinek czerwonych, w tym do antygenów o wysokiej oraz o niskiej częstości występowania

\begin{tabular}{|c|c|c|c|}
\hline Rodzaj badania & Metoda & Materiał* & Wartości referencyjne \\
\hline $\begin{array}{l}\text { Identyfikacja alloprzeciwciał } \\
\text { z } 1 \text { układu grupowego }\end{array}$ & $\begin{array}{l}\text { Techniki mikrokolumnowa } \\
\text { i probówkowa }\end{array}$ & $\begin{array}{l}\text { Krew na skrzep } 5 \mathrm{ml} \\
\text { Krew pełna (EDTA) } 5 \mathrm{ml}\end{array}$ & $\begin{array}{l}\text { Aglutynacja krwinek/brak } \\
\text { aglutynacji }\end{array}$ \\
\hline $\begin{array}{l}\text { Identyfikacja alloprzeciwciał } \\
\text { wieloswoistych }\end{array}$ & $\begin{array}{l}\text { Techniki mikrokolumnowa } \\
\text { i probówkowa }\end{array}$ & $\begin{array}{l}\text { Krew na skrzep min. } 5 \mathrm{ml} \\
\text { Krew pełna (EDTA) } \min .5 \mathrm{ml}\end{array}$ & $\begin{array}{l}\text { Aglutynacja krwinek/brak } \\
\text { aglutynacji }\end{array}$ \\
\hline $\begin{array}{l}\text { Identyfikacja alloprzeciwciał } \\
\text { do antygenu powszechnego }\end{array}$ & $\begin{array}{l}\text { Techniki mikrokolumnowa } \\
\text { i probówkowa }\end{array}$ & $\begin{array}{l}\text { Krew na skrzep min. } 5 \mathrm{ml} \\
\text { Krew pełna (EDTA) min. } 5 \mathrm{ml}\end{array}$ & $\begin{array}{l}\text { Aglutynacja krwinek/brak } \\
\text { aglutynacji }\end{array}$ \\
\hline $\begin{array}{l}\text { Identyfikacja przeciwciał do } \\
\text { antygenu o niskiej częstości } \\
\text { występowania }\end{array}$ & $\begin{array}{l}\text { Techniki mikrokolumnowa } \\
\text { i probówkowa }\end{array}$ & $\begin{array}{l}\text { Krew na skrzep } 5 \mathrm{ml} \\
\text { Krew pełna (EDTA) } 5 \mathrm{ml}\end{array}$ & $\begin{array}{l}\text { Aglutynacja krwinek /brak } \\
\text { aglutynacji }\end{array}$ \\
\hline $\begin{array}{l}\text { Określanie miana przeciwciał } \\
\text { odpornościowych spoza ukła- } \\
\text { du ABO }\end{array}$ & Technika mikrokolumnowa & $\begin{array}{l}\text { Krew na skrzep } 5 \mathrm{ml} \text { lub krew } \\
\text { pełna (EDTA) } 5 \mathrm{ml}\end{array}$ & $\begin{array}{l}\text { Aglutynacja krwinek /brak } \\
\text { aglutynacji }\end{array}$ \\
\hline
\end{tabular}

4) określanie fenotypów oraz słabych odmian antygenów krwinek biorcy i dawców

\begin{tabular}{|c|c|c|c|}
\hline Oznaczenie & Metoda & Materiał & Wartości referencyjne \\
\hline Oznaczenie fenotypu Rh & $\begin{array}{l}\text { Technika mikrokolumnowa } \\
\text { lub probówkowa }\end{array}$ & Krew pełna (EDTA) $5 \mathrm{ml}$ & $\begin{array}{l}\text { Aglutynacja krwinek/brak } \\
\text { aglutynacji }\end{array}$ \\
\hline Oznaczenie fenotypu MNS & $\begin{array}{l}\text { Technika mikrokolumnowa } \\
\text { lub probówkowa }\end{array}$ & Krew pełna (EDTA) $5 \mathrm{ml}$ & $\begin{array}{l}\text { Aglutynacja krwinek/brak } \\
\text { aglutynacji }\end{array}$ \\
\hline Oznaczenie fenotypu Kidd & $\begin{array}{l}\text { Technika mikrokolumnowa } \\
\text { lub probówkowa }\end{array}$ & Krew pełna (EDTA) $5 \mathrm{ml}$ & $\begin{array}{l}\text { Aglutynacja krwinek/brak } \\
\text { aglutynacji }\end{array}$ \\
\hline Oznaczenie fenotypu Duffy & $\begin{array}{l}\text { Technika mikrokolumnowa } \\
\text { lub probówkowa }\end{array}$ & Krew pełna (EDTA) $5 \mathrm{ml}$ & $\begin{array}{l}\text { Aglutynacja krwinek/brak } \\
\text { aglutynacji }\end{array}$ \\
\hline Oznaczenie fenotypu Lewis & Technika probówkowa & Krew pełna (EDTA) $5 \mathrm{ml}$ & $\begin{array}{l}\text { Aglutynacja krwinek/brak } \\
\text { aglutynacji }\end{array}$ \\
\hline Oznaczenie antygenów $\mathrm{K} \mathrm{i} \mathrm{k}$ & $\begin{array}{l}\text { Technika mikrokolumnowa } \\
\text { lub probówkowa }\end{array}$ & Krew pełna (EDTA) $5 \mathrm{ml}$ & $\begin{array}{l}\text { Aglutynacja krwinek/brak } \\
\text { aglutynacji }\end{array}$ \\
\hline $\begin{array}{l}\text { Oznaczenie fenotypu/anty- } \\
\text { genu o wysokiej lub niskiej } \\
\text { częstości występowania }\end{array}$ & $\begin{array}{l}\text { Techniki mikrokolumnowa } \\
\text { i probówkowa }\end{array}$ & Krew pełna (EDTA) $5 \mathrm{ml}$ & $\begin{array}{l}\text { Aglutynacja krwinek/brak } \\
\text { aglutynacji }\end{array}$ \\
\hline
\end{tabular}

5) serologiczna charakterystyka słabych wariantów antygenów

\begin{tabular}{|l|l|l|l|}
\hline Oznaczenie & Metoda & Materiał & Wartości referencyjne \\
\hline $\begin{array}{l}\text { Badanie konsultacyjne grupy } \\
\text { krwi ABO }\end{array}$ & $\begin{array}{l}\text { Techniki mikrokolumnowa } \\
\text { i probówkowa } \\
\text { Adsorpcja elucja }\end{array}$ & $\begin{array}{l}\text { Krew pełna (EDTA) 2 } \\
\text { Krew na skrzep 5 ml }\end{array}$ & $\begin{array}{l}\text { Aglutynacja krwinek/brak } \\
\text { aglutynacji }\end{array}$ \\
\hline $\begin{array}{l}\text { Określenie odmiany antyge- } \\
\text { nu D }\end{array}$ & $\begin{array}{l}\text { Techniki mikrokolumnowa } \\
\text { i probówkowa }\end{array}$ & Krew pełna (EDTA) 2 $24 \mathrm{ml}$ & $\begin{array}{l}\text { Aglutynacja krwinek/brak } \\
\text { aglutynacji }\end{array}$ \\
\hline Określenie antygenu Del & Adsorpcja elucja & Krew pełna (EDTA) 2 $\times 4 \mathrm{ml}$ & $\begin{array}{l}\text { Aglutynacja krwinek/brak } \\
\text { aglutynacji }\end{array}$ \\
\hline
\end{tabular}

6) ponadto w Pracowni są wykonywane badania weryfikacyjne typu WE (procedura, wg której jednostka notyfikowana bada i następnie zaświadcza, że zgłoszony do badania wyrób medyczny do diagnostyki in vitro spełnia odnoszące się do niego wymagania) dotyczą- ce odczynników stosowanych w immunologii transfuzjologicznej.

Do przeprowadzania tych badań Instytut został wytypowany przez jednostkę notyfikowaną - Polskie Centrum Badań i Certyfikacji (podane w tabeli poniżej); 


\begin{tabular}{|l|l|l|l|}
\hline Oznaczenie & Metoda & Materiał* & Wartości referencyjne \\
\hline $\begin{array}{l}\text { Badanie, ocena i opinia dot. odczyn- } \\
\text { ników anty-A i anty-B }\end{array}$ & $\begin{array}{l}\text { Techniki probówkowa } \\
\text { i szkiełkowa }\end{array}$ & $\begin{array}{l}\text { Próbki przesłane } \\
\text { przez producenta }\end{array}$ & $\begin{array}{l}\text { Aglutynacja krwinek/brak aglutynacji } \\
\text { Minimalne miano przeciwciał: } \\
\text { test szkiełkowy } 32 \\
\text { test probówkowy } 64\end{array}$ \\
\hline $\begin{array}{l}\text { Badanie, ocena i opinia dot. odczyn- } \\
\text { ników anty-D, anty-C, anty-c, anty-E, } \\
\text { anty-e, anty-K }\end{array}$ & $\begin{array}{l}\text { Technika probów- } \\
\text { kowa }\end{array}$ & $\begin{array}{l}\text { Próbki przesłane } \\
\text { przez producenta }\end{array}$ & $\begin{array}{l}\text { Aglutynacja krwinek/brak aglutynacji } \\
\text { Minimalne miano przeciwciał - test } \\
\text { probówkowy 8-16 }\end{array}$ \\
\hline $\begin{array}{l}\text { Badanie, ocena i opinia dot. odczyn- } \\
\text { ników antyglobulinowych }\end{array}$ & $\begin{array}{l}\text { Technika probów- } \\
\text { kowa }\end{array}$ & $\begin{array}{l}\text { Próbki przesłane } \\
\text { przez producenta }\end{array}$ & Aglutynacja krwinek/brak aglutynacji \\
\hline $\begin{array}{l}\text { Badanie, ocena i opinia dot. odczyn- } \\
\text { nika papainowanego }\end{array}$ & $\begin{array}{l}\text { Technika probów- } \\
\text { kowa }\end{array}$ & $\begin{array}{l}\text { Próbki przesłane } \\
\text { przez producenta }\end{array}$ & Aglutynacja krwinek/brak aglutynacji \\
\hline $\begin{array}{l}\text { Badanie, ocena i opinia dot. krwinek do } \\
\text { wykrywania i identyfikacji przeciwciał }\end{array}$ & $\begin{array}{l}\text { Techniki mikrokolum- } \\
\text { nowa i probówkowa }\end{array}$ & $\begin{array}{l}\text { Próbki przesłane } \\
\text { przez producenta }\end{array}$ & Aglutynacja krwinek/brak aglutynacji \\
\hline $\begin{array}{l}\text { Badanie, ocena i opinia dot. krwinek } \\
\text { do układu ABO }\end{array}$ & $\begin{array}{l}\text { Technika probów- } \\
\text { kowa }\end{array}$ & $\begin{array}{l}\text { Próbki przesłane } \\
\text { przez producenta }\end{array}$ & Aglutynacja krwinek/brak aglutynacji \\
\hline $\begin{array}{l}\text { Badanie, ocena i opinia dot. krwinek } \\
\text { opłaszczonych przeciwciałami do kon- } \\
\text { troli ujemnych wyników w BTA i PTA }\end{array}$ & $\begin{array}{l}\text { Technika probów- } \\
\text { kowa }\end{array}$ & $\begin{array}{l}\text { Próbki przesłane } \\
\text { przez producenta }\end{array}$ & Aglutynacja krwinek/brak aglutynacji \\
\hline $\begin{array}{l}\text { Badanie, ocena i opinia o ilościo- } \\
\text { wej zawartości przeciwciał anty-D } \\
\text { w standardzie anty-D }\end{array}$ & $\begin{array}{l}\text { Metoda cytometrycz- } \\
\text { na }\end{array}$ & $\begin{array}{l}\text { Próbki przesłane } \\
\text { przez producenta }\end{array}$ & $\begin{array}{l}\text { Pomiar komórek świecących, odczyt } \\
\text { z krzywej wzorcowej z podaniem } \\
\text { miana przeciwciał anty-D } \pm 10 \%\end{array}$ \\
\hline
\end{tabular}

*Badania są wykonywane w próbkach przesłanych przez producenta, jako próbki reprezentujące dany odczynnik, wg standardów międzynarodowych NISBC

W Pracowni przeprowadza się także badanie i ocenę oraz wydaje opinię o systemach automatycznych i półautomatycznych do badań grup krwi i wykrywania przeciwciał odpornościowych oraz badania ilościowe służące określeniu aktywności przeciwciał anty-D w produkcie leczniczym immunoglobuliny anty-RhD (Gamma anty-D 50 i Gamma anty-D 150), jak również jest organizowany i prowadzony Krajowy Program Zewnętrznej Oceny Jakości dla Laboratoriów Immunologii Transfuzjologicznej.

\section{Pracownia Immunologii Leukocytów i Płytek Krwi}

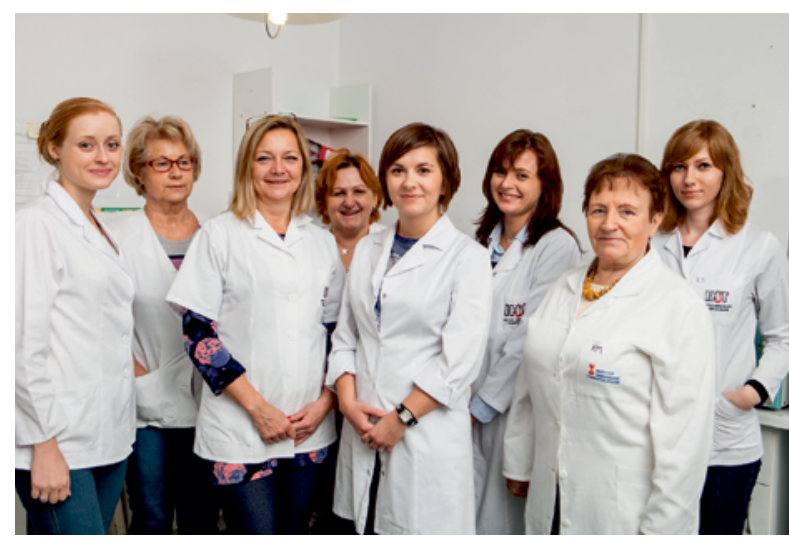

Kierownik: mgr Patrycja Łopacz

Zespół: mgr Anna Główka, mgr Agnieszka Gierszon, inż. st. tech. Jadwiga Sak-Budzisz, st. tech. Halina Nasiegniewska, st. tech. Beata Sierocka, mgr Ewelina Sokół, mgr Magdalena Piłat

Adres: ul. Chocimska 5, 00-791 Warszawa tel.: 223496 947; 223496 615; 223496675 e-mail: plopacz@ihit.waw.pl
Pracownia, jako jedyna w Polsce, prowadzi wysokospecjalistyczne badania obejmujące diagnostykę:

- konfliktu matczyno-płodowego w zakresie antygenów płytek krwi;

- auto-/alloimmunologicznych małopłytkowości;

- małopłytkowości zależnej od heparyny;

- małopłytkowości rzekomej (pseudotrombocytopenii);

- niedoborów glikoprotein błonowych płytek krwi (trombastenia Glanzmanna, zespół Bernarda-Souliera);

- fenotypowania antygenu HPA-1 (ocena ryzyka wystąpienia konfliktu matczyno-płodowego związanego $\mathrm{z}$ brakiem antygenu HPA-1a);

- immunologicznych przyczyn oporności na przetaczane koncentraty płytek krwi;

- przeciwciał anty-HLA klas I i II (wiążących i niewiążących dopełniacza); 
- doboru dawców płytek krwi w próbach zgodności leukocytarno-płytkowych dla pacjentów uodpornionych;

- granulocytopenii pierwotnych i wtórnych;

- niehemolitycznych odczynów poprzetoczeniowych, w tym ostrej poprzetoczeniowej niewydolności oddechowej (TRALI, transfusion-related acute lung injury);

- liczby retikulopłytek we krwi.
Ponadto Pracownia prowadzi działalność konsultacyjną związaną ze specyfiką wykonywanych w niej badań, bierze udział w organizacji programu zewnętrznej kontroli jakości dla CKiK oraz prowadzi działalność naukowo-badawczą.

Badania wykonywane w Pracowni Immunologii Leukocytów i Płytek Krwi podano w poniższej tabeli.

\begin{tabular}{|c|c|c|c|}
\hline Oznaczenie & Metoda/odczyt & Materiał & Wartości referencyjne \\
\hline $\begin{array}{l}\text { Diagnostyka konfliktu matczyno- } \\
\text {-płodowego w zakresie antyge- } \\
\text { nów płytek krwi }\end{array}$ & $\begin{array}{l}\text { Pakiet badań: enzyma- } \\
\text { tycznych, immunofluore- } \\
\text { scencyjnych, Luminex }{ }^{\circledR} \\
\text { genetycznych }\end{array}$ & $\begin{array}{l}\text { Matka; krew na } \\
\text { - } \quad \text { skrzep }(5 \mathrm{ml}) \\
\text { - } \text { EDTA }(10 \mathrm{ml}) \\
\text { - EDTA }(2 \mathrm{ml}) \\
\text { Ojciec; krew na: } \\
\text { - EDTA }(10 \mathrm{ml}) \\
\text { - EDTA }(2 \mathrm{ml})\end{array}$ & $\begin{array}{l}\text { Kompleksowa analiza wszystkich } \\
\text { zastosowanych testów oznaczania } \\
\text { antygenów i wykrywania przeciwciał, } \\
\text { wydanie wyniku potwierdzającego } \\
\text { lub wykluczającego konflikt wraz } \\
\text { z komentarzem oraz zaleceniami }\end{array}$ \\
\hline $\begin{array}{l}\text { Diagnostyka konfliktu matczyno- } \\
\text {-płodowego w zakresie antyge- } \\
\text { nów granulocytów }\end{array}$ & $\begin{array}{l}\text { Pakiet badań: enzymatycz- } \\
\text { nych, immunofluorescen- } \\
\text { cyjnych, aglutynacyjnych, } \\
\text { Luminex }{ }^{\circledR}, \text { genetycznych }\end{array}$ & $\begin{array}{l}\text { Matka; krew na: } \\
\text { - skrzep }(5 \mathrm{ml}) \\
\text { - EDTA }(10 \mathrm{ml}) \\
\text { - EDTA }(2 \mathrm{ml}) \\
\text { - Ojciec; krew na: } \\
\text { - EDTA }(10 \mathrm{ml}) \\
\text { - EDTA }(2 \mathrm{ml})\end{array}$ & $\begin{array}{l}\text { Kompleksowa analiza wszystkich } \\
\text { zastosowanych testów oznaczania } \\
\text { antygenów i wykrywania przeciwciał, } \\
\text { wydanie wyniku potwierdzającego } \\
\text { lub wykluczającego konflikt wraz } \\
\text { z komentarzem oraz zaleceniami }\end{array}$ \\
\hline $\begin{array}{l}\text { Wykrywanie przeciwciał prze- } \\
\text { ciwpłytkowych związanych } \\
\text { z płytkami krwi (BIFT) }\end{array}$ & $\begin{array}{l}\text { Metoda immunofluore- } \\
\text { scencyjna }\end{array}$ & $\begin{array}{l}\text { Krew na EDTA } \\
(10 \mathrm{ml})^{*}\end{array}$ & $\begin{array}{l}\text { Przeciwciała obecne przy > } 10 \% \\
\text { populacji komórek znakowanych } \\
\text { przeciwciałem sprzężonym z fluoro- } \\
\text { chromem }\end{array}$ \\
\hline $\begin{array}{l}\text { Wykrywanie przeciwciał prze- } \\
\text { ciwpłytkowych w surowicy } \\
\text { (MAIPA) }\end{array}$ & Metoda enzymatyczna & $\begin{array}{l}\text { Krew na skrzep } \\
(5 \mathrm{ml})^{\star *}\end{array}$ & O.D. $>0,200$ \\
\hline $\begin{array}{l}\text { Próba zgodności z płytkami krwi } \\
\text { w teście MAIPA }\end{array}$ & Metoda enzymatyczna & $\begin{array}{l}\text { Pacjent: krew na } \\
\text { skrzep (5 ml) } \\
\text { Dawca kkp: krew } \\
\text { na EDTA }(10 \mathrm{ml})\end{array}$ & O.D. $>0,200$ \\
\hline $\begin{array}{l}\text { Wykrywanie przeciwciał prze- } \\
\text { ciwpłytkowych oraz anty-HLA } \\
\text { klasy I (test PakLx) }\end{array}$ & Luminex $^{\circledR}$ & $\begin{array}{l}\text { Krew na skrzep } \\
(5 \mathrm{ml})^{* *}\end{array}$ & Analiza MFI wg zaleceń producenta \\
\hline $\begin{array}{l}\text { Wykrywanie przeciwciał prze- } \\
\text { ciwpłytkowych w surowicy } \\
\text { (PAKPLUS Immucor) }\end{array}$ & $\begin{array}{l}\text { Metoda enzymatyczna - } \\
\text { firmowy zestaw diagno- } \\
\text { styczny }\end{array}$ & $\begin{array}{l}\text { Krew na skrzep } \\
(5 \mathrm{ml})^{\star *}\end{array}$ & $\begin{array}{l}\text { Wg wzoru podanego przez produ- } \\
\text { centa }\end{array}$ \\
\hline $\begin{array}{l}\text { Fenotypowanie antygenu HPA-1 } \\
\text { screening }\end{array}$ & $\begin{array}{l}\text { Metoda immunofluore- } \\
\text { scencyjna }\end{array}$ & $\begin{array}{l}\text { Krew na EDTA } \\
(4,9 \mathrm{ml})\end{array}$ & MFI $>200$ \\
\hline $\begin{array}{l}\text { Wykrywanie przeciwciał prze- } \\
\text { ciwpłytkowych EDTA-zależnych }\end{array}$ & $\begin{array}{l}\text { Metoda immunofluore- } \\
\text { scencyjna } \\
\text { Metoda mikroskopowa }\end{array}$ & $\begin{array}{l}\text { Krew na skrzep } \\
(5 \mathrm{ml})\end{array}$ & $\begin{array}{l}\text { Przeciwciała obecne przy > 10\% popu- } \\
\text { lacji komórek znakowanych przeciw- } \\
\text { ciałem sprzężonym z fluorochromem; } \\
\text { aglutynacja komórek/brak aglutynacji }\end{array}$ \\
\hline $\begin{array}{l}\text { Wykrywanie przeciwciał hepa- } \\
\text { rynozależnych (przeciwko kom- } \\
\text { pleksowi PF4/heparyna) (test } \\
\text { X-HAT45 Immucor) }\end{array}$ & $\begin{array}{l}\text { Metoda enzymatyczna- } \\
\text { firmowy zestaw diagno- } \\
\text { styczny }\end{array}$ & $\begin{array}{l}\text { Krew na skrzep } \\
(5 \mathrm{ml})^{\star * *}\end{array}$ & O.D. $>0,400$ \\
\hline
\end{tabular}




\begin{tabular}{|c|c|c|c|}
\hline Oznaczenie & Metoda/odczyt & Materiał & Wartości referencyjne \\
\hline $\begin{array}{l}\text { Ocena ekspresji GPIb/IX/V pły- } \\
\text { tek krwi (diagnostyka zespołu } \\
\text { Bernarda-Souliera) }\end{array}$ & $\begin{array}{l}\text { Metoda immunofluore- } \\
\text { scencyjna }\end{array}$ & $\begin{array}{l}\text { Krew na EDTA } \\
(10 \mathrm{ml} \times 2)\end{array}$ & $\begin{array}{l}\text { Porównanie ekspresji GPIb/IX/V na } \\
\text { płytkach krwi pacjenta i dawców pa- } \\
\text { nelowych }\end{array}$ \\
\hline $\begin{array}{l}\text { Ocena ekspresji GPIlb/IIla płytek } \\
\text { krwi (diagnostyka trombastenii } \\
\text { Glanzmanna)**** }\end{array}$ & $\begin{array}{l}\text { Metoda immunofluore- } \\
\text { scencyjna }\end{array}$ & $\begin{array}{l}\text { Krew na EDTA } \\
(10 \mathrm{ml} \times 2)\end{array}$ & $\begin{array}{l}\text { Porównanie ekspresji GPIlb/llla na } \\
\text { płytkach krwi pacjenta i dawców pa- } \\
\text { nelowych }\end{array}$ \\
\hline $\begin{array}{l}\text { Wykrywanie przeciwciał prze- } \\
\text { ciwgranulocytarnych } \\
\text { Pakiet: MAIGA/GAT/GIFT }\end{array}$ & $\begin{array}{l}\text { Pakiet badań: immunoflu- } \\
\text { orescencyjnych, enzyma- } \\
\text { tycznych, aglutynacyjnych }\end{array}$ & $\begin{array}{l}\text { Krew na skrzep } \\
(5 \mathrm{ml})\end{array}$ & $\begin{array}{l}\text { Analiza wyników wszystkich wykona- } \\
\text { nych badań }\end{array}$ \\
\hline $\begin{array}{l}\text { Wykrywanie przeciwciał przeciw- } \\
\text { granulocytarnych oraz anty-HLA } \\
\text { klas I i II } \\
\text { Pakiet: LABScreen Multi/GAT/GIFT }\end{array}$ & $\begin{array}{l}\text { Pakiet badań: immunoflu- } \\
\text { orescencyjnych, aglutyna- } \\
\text { cyjnych, Luminex }\end{array}$ & $\begin{array}{l}\text { Krew na skrzep } \\
(5 \mathrm{ml})\end{array}$ & $\begin{array}{l}\text { Analiza wyników wszystkich wykona- } \\
\text { nych badań }\end{array}$ \\
\hline $\begin{array}{l}\text { Wykrywanie przeciwciał prze- } \\
\text { ciwgranulocytarnych w surowicy } \\
\text { (MAIGA) }\end{array}$ & Metoda enzymatyczna & $\begin{array}{l}\text { Krew na skrzep } \\
(5 \mathrm{ml})\end{array}$ & O.D. $>0,200$ \\
\hline $\begin{array}{l}\text { Wykrywanie przeciwciał prze- } \\
\text { ciwgranulocytarnych w surowicy } \\
\text { (GIFT) }\end{array}$ & $\begin{array}{l}\text { Metoda immunofluore- } \\
\text { scencyjna }\end{array}$ & $\begin{array}{l}\text { Krew na skrzep } \\
(5 \mathrm{ml})\end{array}$ & $\begin{array}{l}\text { Przeciwciała obecne przy > } 10 \% \\
\text { populacji komórek znakowanych } \\
\text { przeciwciałem sprzężonym z fluoro- } \\
\text { chromem }\end{array}$ \\
\hline $\begin{array}{l}\text { Wykrywanie przeciwciał prze- } \\
\text { ciwgranulocytarnych w surowicy } \\
\text { (GAT) }\end{array}$ & Metoda aglutynacji & $\begin{array}{l}\text { Krew na skrzep } \\
(5 \mathrm{ml})\end{array}$ & Aglutynacja komórek/brak aglutynacji \\
\hline $\begin{array}{l}\text { Wykrywanie przeciwciał przeciw- } \\
\text { granulocytarnych oraz anty-HLA } \\
\text { kl. I i kl. Il (test LABScreen Multi) }\end{array}$ & Luminex $^{\circledR}$ & $\begin{array}{l}\text { Krew na skrzep } \\
(5 \mathrm{ml})\end{array}$ & $\begin{array}{l}\text { Analiza NBG oraz MFI wg zaleceń } \\
\text { producenta }\end{array}$ \\
\hline $\begin{array}{l}\text { Wykrywanie przeciwciał limfocy- } \\
\text { totoksycznych (LCT) }\end{array}$ & Test limfocytotoksyczny & $\begin{array}{l}\text { Krew na skrzep } \\
(5 \mathrm{ml})^{\star *}\end{array}$ & $\begin{array}{l}\text { Aktywność limfocytotoksyczna oce- } \\
\text { niana w skali 8-punktowej }\end{array}$ \\
\hline $\begin{array}{l}\text { Próba zgodności z limfocytami } \\
\text { w teście LCT }\end{array}$ & Test limfocytotoksyczny & $\begin{array}{l}\text { Pacjent: krew na } \\
\text { skrzep (5 ml) } \\
\text { Dawca kkp: krew } \\
\text { na EDTA }(10 \mathrm{ml})\end{array}$ & $\begin{array}{l}\text { Aktywność limfocytotoksyczna oce- } \\
\text { niana w skali 8-punktowej }\end{array}$ \\
\hline $\begin{array}{l}\text { Wykrywanie przeciwciał anty-HLA } \\
\text { klas I i II (test LABScreen Mixed) }\end{array}$ & Luminex $^{\circledR}$ & $\begin{array}{l}\text { Krew na skrzep } \\
(5 \mathrm{ml})^{* *}\end{array}$ & $\begin{array}{l}\text { Analiza NBG oraz MFI wg zaleceń } \\
\text { producenta }\end{array}$ \\
\hline $\begin{array}{l}\text { Wykrywanie przeciwciał anty- } \\
\text {-HLA klas I i II (ELISA) }\end{array}$ & Metoda enzymatyczna & $\begin{array}{l}\text { Krew na skrzep } \\
(5 \mathrm{ml})^{\star *}\end{array}$ & $\begin{array}{l}\text { Wg wzoru podanego przez produ- } \\
\text { centa }\end{array}$ \\
\hline $\begin{array}{l}\text { Oznaczanie liczby retikulopłytek } \\
\text { we krwi*** }\end{array}$ & $\begin{array}{l}\text { Metoda immunofluore- } \\
\text { scencyjna }\end{array}$ & $\begin{array}{l}\text { Krew na EDTA } \\
(2,7 \mathrm{ml})\end{array}$ & $0,5-6,0 \%$ \\
\hline $\begin{array}{l}\text { Diagnostyka odczynu poprzeto- } \\
\text { czeniowego typu TRALI }\end{array}$ & \multirow{2}{*}{$\begin{array}{l}\text { Pakiet badań: immunoflu- } \\
\text { orescencyjnych, enzyma- } \\
\text { tycznych, aglutynacyjnych, } \\
\text { Luminex }^{\circledR}\end{array}$} & \multirow{2}{*}{$\begin{array}{l}\text { Pacjent: surowica } \\
\text { przed i po transfuzji } \\
\text { Składniki krwi } \\
\text { pojemniki z pozo- } \\
\text { stałościami przeto- } \\
\text { czonych składników } \\
\text { krwi, dreny***** }\end{array}$} & \multirow[t]{2}{*}{$\begin{array}{l}\text { Interpretacja otrzymanych wyników } \\
\text { badań }\end{array}$} \\
\hline $\begin{array}{l}\text { Diagnostyka odczynu poprzeto- } \\
\text { czeniowego }\end{array}$ & & & \\
\hline
\end{tabular}

*Wykonanie testu BIFT jest możliwe w przypadku, gdy liczba płytek u chorego > 25 000/ $\mu$ l; **jeżeli u chorego zlecono jednocześnie badania: LCT/ELISA/LABScreen Mixed, MAIPA lub PakLx, to pobrać tylko $5 \mathrm{ml}$ krwi na skrzep/surowicę; ***badanie musi być wykonane tego samego dnia, co pobranie, a materiał musi dotrzeć do pracowni do godz. 11:00; ****badanie należy wcześniej umówić telefonicznie - jest wykonywane tylko w poniedziałki; ***** $w$ przypadku zlecenia odczynów poprzetoczeniowych niezbędne jest dołączenie Formularza Zgłoszenia Powikłania Poprzetoczeniowego 


\section{Pracownia Immunopatologii Ciąży}

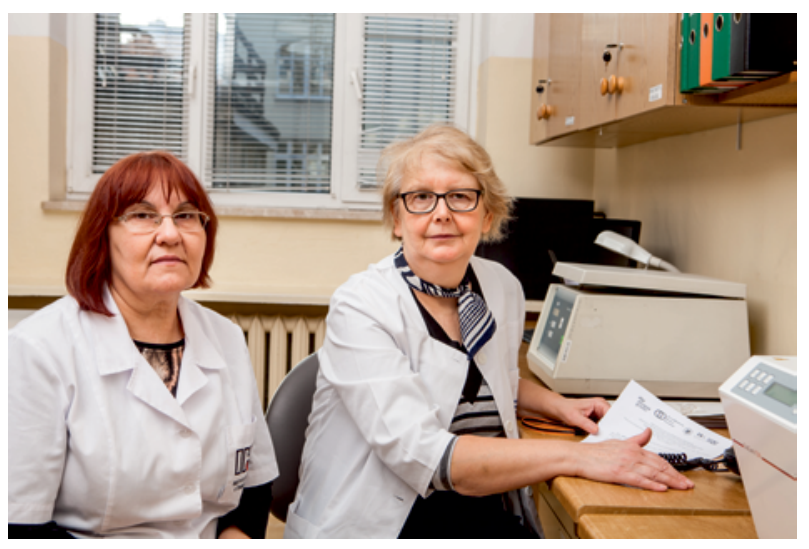

Kierownik: dr n. med. Małgorzata Uhrynowska

Zespół: mgr Magdalena Michalik, mgr Pamela Bartoszewicz, Anna Plizak

Adres: ul. Chocimska 5, 00-791 Warszawa

tel.: 223496 668; 223496671

e-mail: muhrynowska@ihit.waw.pl

W Pracowni są wykonywane przesiewowe i diagnostyczne badania serologiczne u wszystkich kobiet w ciąży (RhD-ujemnych i RhD-dodatnich) w celu wykluczenia/potwierdzenia konfliktu matczyno-płodowego w zakresie krwinek czerwonych. Badania te powinny być przeprowadzane u wszystkich kobiet w ciąży 2-krotnie do 10 . tygodnia ciąży i w 27.-32. tygodniu ciąży, a u kobiet RhD-ujemnych — dodatkowo w 21.-26. tygodniu ciąży (rozporządzenie ministra zdrowia z 20.09.2012 r., Dz.U. z 2012 r., poz. 1100). Są one niezbędne do zdiagnozowania konfliktu i ustalenia, jaką krew należy dobrać/podać dziecku lub matce w przypadku wskazań do przetoczenia. Gdy wykrywane są przeciwciała do wielu antygenów lub do antygenu powszechnie występującego w populacji, to ustalenie ich swoistości $z$ odpowiednim wyprzedzeniem jest konieczne w celu znalezienia dawcy do przetoczenia. O wykryciu takich przeciwciał należy poinformować CKiK, by taką krew zabezpieczyło. Badania wykonywane u kobiety wymieniono $\mathrm{w}$ tabeli poniżej.

Pracownia współpracuje z Pracownią Komórek Krwi i Chimeryzmu w nieinwazyjnym genotypowaniu antygenów płodu w celu wykluczenia ryzyka choroby hemolitycznej, gdy płód nie ma antygenu, do którego są skierowane przeciwciała matki, oraz z Pracownią Konsultacyjną Immunologii Krwinki Czerwonej, w której wykonuje się badania przeciwciał do antygenów powszechnie występujących.

Wykonuje się również badanie przesiewowe antygenu HPA-1a płytek krwi, antygenu odgrywającego dominującą rolę w konflikcie matczyno-płodowym w zakresie krwinek płytkowych.

Badania wykonywane w Pracowni Immunopatologii Ciąży podano w poniższej tabeli.

\begin{tabular}{|c|c|c|c|c|c|}
\hline Nazwa badania & Metoda & Materiał & $\begin{array}{l}\text { Wartości referen- } \\
\text { cyjne }\end{array}$ & $\begin{array}{l}\text { Sposób transportu/ } \\
\text { warunki transportu }\end{array}$ & $\begin{array}{l}\text { Maksymalny } \\
\text { czas ocze- } \\
\text { kiwania na } \\
\text { wynik }\end{array}$ \\
\hline $\begin{array}{l}\text { Diagnostyka choroby } \\
\text { hemolitycznej nowo- } \\
\text { rodka w układzie ABO } \\
\text { u kobiety w ciąży }\end{array}$ & $\begin{array}{l}\text { Manualna tech- } \\
\text { nika mikrokolum- } \\
\text { nowa }\end{array}$ & $\begin{array}{l}\text { Matka: krew peł- } \\
\text { na (skrzep) } 10 \mathrm{ml} \\
\text { Noworodek:krew } \\
\text { pełna (EDTA) } 5 \mathrm{ml}\end{array}$ & $\begin{array}{l}\text { Reakcja aglutynacji } \\
\text { krwinek/brak aglu- } \\
\text { tynacji krwinek }\end{array}$ & $\begin{array}{l}\text { Temp. } 18-22^{\circ} \mathrm{C}: \text { do } \\
48 \mathrm{~h} \\
\text { Temp. } 2-8^{\circ} \mathrm{C}: \text { do } 7 \mathrm{dni}\end{array}$ & $1-2 \mathrm{dni}$ \\
\hline $\begin{array}{l}\text { Identyfikacja alloprze- } \\
\text { ciwciał z } 1 \text { układu gru- } \\
\text { powego }\end{array}$ & $\begin{array}{l}\text { Manualna tech- } \\
\text { nika mikrokolum- } \\
\text { nowa }\end{array}$ & $\begin{array}{l}\text { Krew pełna } \\
\text { (skrzep } 10 \mathrm{ml}) / \\
\text { /krew pełna } \\
\text { (EDTA) } 5 \mathrm{ml}\end{array}$ & $\begin{array}{l}\text { Reakcja aglutynacji } \\
\text { krwinek/brak aglu- } \\
\text { tynacji krwinek }\end{array}$ & $\begin{array}{l}\text { Temp. } 18-22^{\circ} \mathrm{C}: \text { do } \\
48 \mathrm{~h} \\
\text { Temp. } 2-8^{\circ} \mathrm{C}: \text { do } 7 \mathrm{dni}\end{array}$ & $1-2 \mathrm{dni}$ \\
\hline $\begin{array}{l}\text { Identyfikacja alloprze- } \\
\text { ciwciał wieloswoistych }\end{array}$ & $\begin{array}{l}\text { Manualna tech- } \\
\text { nika mikrokolum- } \\
\text { nowa }\end{array}$ & $\begin{array}{l}\text { Krew pełna } \\
\text { (skrzep) } 10 \mathrm{ml} / \\
\text { /krew pełna } \\
\text { (EDTA) } 5 \mathrm{ml}\end{array}$ & $\begin{array}{l}\text { Reakcja aglutynacji } \\
\text { krwinek/brak aglu- } \\
\text { tynacji krwinek }\end{array}$ & $\begin{array}{l}\text { Temp. } 18-22^{\circ} \mathrm{C}: \text { do } \\
48 \mathrm{~h} \\
\text { Temp. } 2-8^{\circ} \mathrm{C}: \text { do } 7 \mathrm{dni}\end{array}$ & $2-3 \mathrm{dni}$ \\
\hline \multirow{2}{*}{$\begin{array}{l}\text { Oznaczenie miana } \\
\text { przeciwciał }\end{array}$} & $\begin{array}{l}\text { Manualna techni- } \\
\text { ka probówkowa }\end{array}$ & $\begin{array}{l}\text { Krew pełna } \\
\text { (skrzep) } 5 \mathrm{ml}\end{array}$ & $\begin{array}{l}\text { Reakcja aglutynacji } \\
\text { krwinek w bada- } \\
\text { nym rozcieńczeniu/ } \\
\text { /brak aglutynacji } \\
\text { krwinek }\end{array}$ & $\begin{array}{l}\text { Temp. } 18-22^{\circ} \mathrm{C}: \text { do } \\
48 \mathrm{~h} \\
\text { Temp. } 2-8^{\circ} \mathrm{C}: \text { do } 7 \mathrm{dni}\end{array}$ & 1 dzień \\
\hline & $\begin{array}{l}\text { Manualna tech- } \\
\text { nika mikrokolum- } \\
\text { nowa }\end{array}$ & $\begin{array}{l}\text { Krew pełna } \\
\text { (skrzep) } 5 \mathrm{ml}\end{array}$ & $\begin{array}{l}\text { Reakcja aglutynacji } \\
\text { krwinek w bada- } \\
\text { nym rozcieńczeniu/ } \\
\text { /brak aglutynacji } \\
\text { krwinek }\end{array}$ & $\begin{array}{l}\text { Temp. } 18-22^{\circ} \mathrm{C}: \text { do } \\
48 \mathrm{~h} \\
\text { Temp. } 2-8^{\circ} \mathrm{C}: \text { do } 7 \mathrm{dni}\end{array}$ & 1 dzień \\
\hline
\end{tabular}




\begin{tabular}{|c|c|c|c|c|c|}
\hline Nazwa badania & Metoda & Materiał & $\begin{array}{l}\text { Wartości referen- } \\
\text { cyjne }\end{array}$ & $\begin{array}{l}\text { Sposób transportu/ } \\
\text { warunki transportu }\end{array}$ & $\begin{array}{l}\text { Maksymalny } \\
\text { czas ocze- } \\
\text { kiwania na } \\
\text { wynik }\end{array}$ \\
\hline $\begin{array}{l}\text { Przeglądowe badanie } \\
\text { na obecność przeciw- } \\
\text { ciał czerwonokrwinko- } \\
\text { wych u kobiet w ciąży }\end{array}$ & $\begin{array}{l}\text { Manualna tech- } \\
\text { nika mikrokolum- } \\
\text { nowa }\end{array}$ & $\begin{array}{l}\text { Krew pełna } \\
\text { (skrzep) } 5 \mathrm{ml}\end{array}$ & $\begin{array}{l}\text { Reakcja aglutynacji } \\
\text { krwinek/brak aglu- } \\
\text { tynacji krwinek }\end{array}$ & $\begin{array}{l}\text { Temp. } 18-22^{\circ} \mathrm{C}: \text { do } \\
48 \mathrm{~h} \\
\text { Temp. } 2-8^{\circ} \mathrm{C}: \text { do } 7 \mathrm{dni}\end{array}$ & 1 dzień \\
\hline $\begin{array}{l}\text { Bezpośredni test anty- } \\
\text { globulinowy u kobiety } \\
\text { w ciąży }\end{array}$ & $\begin{array}{l}\text { Manualna tech- } \\
\text { nika mikrokolum- } \\
\text { nowa }\end{array}$ & $\begin{array}{l}\text { Krew pełna } \\
\text { (skrzep) } 5 \mathrm{ml}\end{array}$ & $\begin{array}{l}\text { Reakcja aglutynacji } \\
\text { krwinek/brak aglu- } \\
\text { tynacji krwinek }\end{array}$ & $\begin{array}{l}\text { Temp. } 18-22^{\circ} \mathrm{C}: \text { do } \\
48 \mathrm{~h} \\
\text { Temp. } 2-8^{\circ} \mathrm{C}: \text { do } 7 \mathrm{dni}\end{array}$ & 1 dzień \\
\hline $\begin{array}{l}\text { Określenie fenotypu } \\
\text { Kidd }\end{array}$ & $\begin{array}{l}\text { Manualna techni- } \\
\text { ka probówkowa }\end{array}$ & $\begin{array}{l}\text { Krew pełna } \\
\text { (skrzep) } 5 \mathrm{ml}\end{array}$ & $\begin{array}{l}\text { Reakcja aglutynacji } \\
\text { krwinek/brak aglu- } \\
\text { tynacji krwinek }\end{array}$ & $\begin{array}{l}\text { Temp. } 18-22^{\circ} \mathrm{C}: \text { do } \\
48 \mathrm{~h} \\
\text { Temp. } 2-8^{\circ} \mathrm{C}: \text { do } 7 \mathrm{dni}\end{array}$ & 1 dzień \\
\hline $\begin{array}{l}\text { Określenie fenotypu } \\
\text { Duffy }\end{array}$ & $\begin{array}{l}\text { Manualna techni- } \\
\text { ka probówkowa }\end{array}$ & $\begin{array}{l}\text { Krew pełna } \\
\text { (skrzep) } 5 \mathrm{ml}\end{array}$ & $\begin{array}{l}\text { Reakcja aglutynacji } \\
\text { krwinek/Brak aglu- } \\
\text { tynacji krwinek }\end{array}$ & $\begin{array}{l}\text { Temp. } 18-22^{\circ} \mathrm{C}: \text { do } \\
48 \mathrm{~h} \\
\text { Temp. } 2-8^{\circ} \mathrm{C}: \text { do } 7 \mathrm{dni}\end{array}$ & 1 dzień \\
\hline $\begin{array}{l}\text { Określenie fenotypu } \\
M ; N ; S ; S\end{array}$ & $\begin{array}{l}\text { Manualna techni- } \\
\text { ka probówkowa }\end{array}$ & $\begin{array}{l}\text { Krew pełna } \\
\text { (skrzep) } 5 \mathrm{ml}\end{array}$ & $\begin{array}{l}\text { Reakcja aglutynacji } \\
\text { krwinek/brak aglu- } \\
\text { tynacji krwinek }\end{array}$ & $\begin{array}{l}\text { Temp. } 18-22^{\circ} \mathrm{C}: \text { do } \\
48 \mathrm{~h} \\
\text { Temp. } 2-8^{\circ} \mathrm{C}: \text { do } 7 \mathrm{dni}\end{array}$ & 1 dzień \\
\hline $\begin{array}{l}\text { Określenie fenotypu } \\
\text { Lewis }\end{array}$ & $\begin{array}{l}\text { Manualna techni- } \\
\text { ka probówkowa }\end{array}$ & $\begin{array}{l}\text { Krew pełna } \\
\text { (skrzep) } 5 \mathrm{ml}\end{array}$ & $\begin{array}{l}\text { Reakcja aglutynacji } \\
\text { krwinek/brak aglu- } \\
\text { tynacji krwinek }\end{array}$ & $\begin{array}{l}\text { Temp. } 18-22^{\circ} \mathrm{C}: \text { do } \\
48 \mathrm{~h} \\
\text { Temp. } 2-8^{\circ} \mathrm{C}: \text { do } 7 \mathrm{dni}\end{array}$ & 1 dzień \\
\hline Określenie antygenu k & $\begin{array}{l}\text { Manualna techni- } \\
\text { ka probówkowa }\end{array}$ & $\begin{array}{l}\text { Krew pełna } \\
\text { (skrzep) } 5 \mathrm{ml}\end{array}$ & $\begin{array}{l}\text { Reakcja aglutynacji } \\
\text { krwinek/brak aglu- } \\
\text { tynacji krwinek }\end{array}$ & $\begin{array}{l}\text { Temp. } 18-22^{\circ} \mathrm{C}: \text { do } \\
48 \mathrm{~h} \\
\text { Temp. } 2-8^{\circ} \mathrm{C}: \text { do } 7 \mathrm{dni}\end{array}$ & 1 dzień \\
\hline $\begin{array}{l}\text { Określenie fenotypu } \\
\text { P } 1\end{array}$ & $\begin{array}{l}\text { Manualna techni- } \\
\text { ka probówkowa }\end{array}$ & $\begin{array}{l}\text { Krew pełna } \\
\text { (skrzep) } 5 \mathrm{ml}\end{array}$ & $\begin{array}{l}\text { Reakcja aglutynacji } \\
\text { krwinek/brak aglu- } \\
\text { tynacji krwinek }\end{array}$ & $\begin{array}{l}\text { Temp. } 18-22^{\circ} \mathrm{C}: \text { do } \\
48 \mathrm{~h} \\
\text { Temp. } 2-8^{\circ} \mathrm{C}: \text { do } 7 \mathrm{dni}\end{array}$ & 1 dzień \\
\hline $\begin{array}{l}\text { Określenie fenotypu } \\
\text { MN }\end{array}$ & $\begin{array}{l}\text { Manualna techni- } \\
\text { ka probówkowa }\end{array}$ & $\begin{array}{l}\text { Krew pełna } \\
\text { (skrzep) } 5 \mathrm{ml}\end{array}$ & $\begin{array}{l}\text { Reakcja aglutynacji } \\
\text { krwinek/brak aglu- } \\
\text { tynacji krwinek }\end{array}$ & $\begin{array}{l}\text { Temp. } 18-22^{\circ} \mathrm{C}: \text { do } \\
48 \mathrm{~h} \\
\text { Temp. } 2-8^{\circ} \mathrm{C}: \text { do } 7 \mathrm{dni}\end{array}$ & 1 dzień \\
\hline Określenie fenotypu Ss & $\begin{array}{l}\text { Manualna techni- } \\
\text { ka probówkowa }\end{array}$ & $\begin{array}{l}\text { Krew pełna } \\
\text { (skrzep) } 5 \mathrm{ml}\end{array}$ & $\begin{array}{l}\text { Reakcja aglutynacji } \\
\text { krwinek/brak aglu- } \\
\text { tynacji krwinek }\end{array}$ & $\begin{array}{l}\text { Temp. } 18-22^{\circ} \mathrm{C}: \text { do } \\
48 \mathrm{~h} \\
\text { Temp. } 2-8^{\circ} \mathrm{C}: \text { do } 7 \mathrm{dni}\end{array}$ & 1 dzień \\
\hline $\begin{array}{l}\text { Określenie fenotypu } \\
\text { Lu }^{\mathrm{a}}\end{array}$ & $\begin{array}{l}\text { Manualna techni- } \\
\text { ka probówkowa }\end{array}$ & $\begin{array}{l}\text { Krew pełna } \\
\text { (skrzep) } 5 \mathrm{ml}\end{array}$ & $\begin{array}{l}\text { Reakcja aglutynacji } \\
\text { krwinek/brak aglu- } \\
\text { tynacji krwinek }\end{array}$ & $\begin{array}{l}\text { Temp. } 18-22^{\circ} \mathrm{C}: \text { do } \\
48 \mathrm{~h} \\
\text { Temp. } 2-8^{\circ} \mathrm{C}: \text { do } 7 \mathrm{dni}\end{array}$ & 1 dzień \\
\hline \multirow{2}{*}{$\begin{array}{l}\text { Określenie fenotypu } \\
\text { Rh i K }\end{array}$} & $\begin{array}{l}\text { Manualna techni- } \\
\text { ka probówkowa }\end{array}$ & $\begin{array}{l}\text { Krew pełna } \\
\text { (skrzep) } 5 \mathrm{ml}\end{array}$ & $\begin{array}{l}\text { Reakcja aglutynacji } \\
\text { krwinek/brak aglu- } \\
\text { tynacji krwinek }\end{array}$ & $\begin{array}{l}\text { Temp. } 18-22^{\circ} \mathrm{C}: \text { do } \\
48 \mathrm{~h} \\
\text { Temp. } 2-8^{\circ} \mathrm{C}: \text { do } 7 \mathrm{dni}\end{array}$ & 1 dzień \\
\hline & $\begin{array}{l}\text { Manualna tech- } \\
\text { nika mikrokolum- } \\
\text { nowa }\end{array}$ & $\begin{array}{l}\text { Krew pełna } \\
\text { (skrzep) } 5 \mathrm{ml}\end{array}$ & $\begin{array}{l}\text { Reakcja aglutynacji } \\
\text { krwinek/brak aglu- } \\
\text { tynacji krwinek }\end{array}$ & $\begin{array}{l}\text { Temp. } 18-22^{\circ} \mathrm{C}: \text { do } \\
48 \mathrm{~h} \\
\text { Temp. } 2-8^{\circ} \mathrm{C}: \text { do } 7 \mathrm{dni}\end{array}$ & 1 dzień \\
\hline Określenie fenotypu Cw & $\begin{array}{l}\text { Manualna techni- } \\
\text { ka probówkowa }\end{array}$ & $\begin{array}{l}\text { Krew pełna } \\
\text { (skrzep) } 5 \mathrm{ml}\end{array}$ & \begin{tabular}{|l|} 
Reakcja aglutynacji \\
krwinek/brak aglu- \\
tynacji krwinek
\end{tabular} & $\begin{array}{l}\text { Temp. } 18-22^{\circ} \mathrm{C}: \text { do } \\
48 \mathrm{~h} \\
\text { Temp. } 2-8^{\circ} \mathrm{C}: \text { do } 7 \mathrm{dni}\end{array}$ & 1 dzień \\
\hline Badanie eluatu & $\begin{array}{l}\text { Manualna techni- } \\
\text { ka probówkowa }\end{array}$ & $\begin{array}{l}\text { Krew pełna (EDTA) } \\
5 \mathrm{ml}\end{array}$ & $\begin{array}{l}\text { Reakcja aglutynacji } \\
\text { krwinek/brak aglu- } \\
\text { tynacji krwinek }\end{array}$ & $\begin{array}{l}\text { Temp. } 18-22^{\circ} \mathrm{C}: \text { do } \\
48 \mathrm{~h} \\
\text { Temp. } 2-8^{\circ} \mathrm{C}: \text { do } 7 \mathrm{dni}\end{array}$ & 1 dzień \\
\hline $\begin{array}{l}\text { Adsorpcja alloprze- } \\
\text { ciwciał }\end{array}$ & $\begin{array}{l}\text { Manualna techni- } \\
\text { ka probówkowa }\end{array}$ & $\begin{array}{l}\text { Krew pełna } \\
\text { (skrzep) } 10 \mathrm{ml}\end{array}$ & $\begin{array}{l}\text { Reakcja aglutynacji } \\
\text { krwinek/brak aglu- } \\
\text { tynacji krwinek }\end{array}$ & $\begin{array}{l}\text { Temp. } 18-22^{\circ} \mathrm{C}: \text { do } \\
48 \mathrm{~h} \\
\text { Temp. } 2-8^{\circ} \mathrm{C}: \text { do } 7 \mathrm{dni}\end{array}$ & 1 dzień \\
\hline $\begin{array}{l}\text { Określenie miana prze- } \\
\text { ciwciał anty-A/anty-B } \\
\text { klas IgG i lgM }\end{array}$ & $\begin{array}{l}\text { Manualna techni- } \\
\text { ka probówkowa }\end{array}$ & $\begin{array}{l}\text { Krew pełna } \\
\text { (skrzep) } 5 \mathrm{ml}\end{array}$ & $\begin{array}{l}\text { Reakcja aglutynacji } \\
\text { krwinek w bada- } \\
\text { nym rozcieńczeniu/ } \\
\text { brak aglutynacji } \\
\text { krwinek }\end{array}$ & $\begin{array}{l}\text { Temp. } 18-22^{\circ} \mathrm{C}: \text { do } \\
48 \mathrm{~h} \\
\text { Temp. } 2-8^{\circ} \mathrm{C}: \text { do } 7 \mathrm{dni}\end{array}$ & 1 dzień \\
\hline $\begin{array}{l}\text { Przesiewowe badanie } \\
\text { antygenu HPA-1a }\end{array}$ & $\begin{array}{l}\text { Cytometria prze- } \\
\text { pływowa }\end{array}$ & $\begin{array}{l}\text { Krew pełna (EDTA) } \\
5 \mathrm{ml}\end{array}$ & $\begin{array}{l}\text { Wynik dodatni: } \\
\text { wartość pomiaru } \\
\text { świecących komó- } \\
\text { rek }>2 \\
\text { Wynik ujemny: } \\
\text { wartość pomiaru } \\
\text { świecących komó- } \\
\text { rek < 200 }\end{array}$ & $\begin{array}{l}\text { Temp. } 18-22^{\circ} \mathrm{C}: 48 \mathrm{~h} \\
\text { Temp. } 2-8^{\circ} \mathrm{C}: \text { do } 7 \mathrm{dni}\end{array}$ & Do 7 dni \\
\hline
\end{tabular}




\section{Pracownia Niedokrwistości Uwarunkowanych Genetycznie}

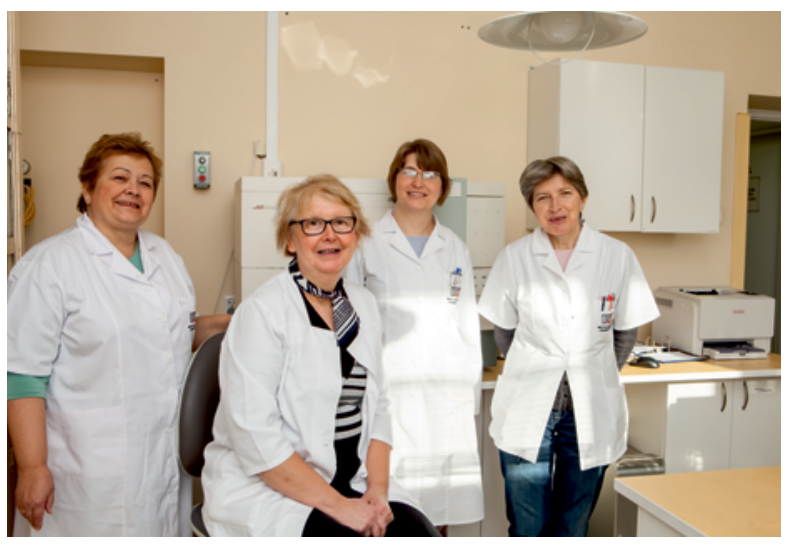

Kierownik: dr n. med. Małgorzata Uhrynowska

Zespół: mgr Ewa Gołaszewska, mgr Edyta Klimczak-Jajor, mgr Anna Myślińska, mgr Hanna Pyl, mgr Justyna Spychalska

Adres: ul. Chocimska 5, 00-791 Warszawa tel.: 223496 668; 223496 677; 223496 658;

223496 673; 223496679

e-mail: muhrynowska@ihit.waw.pl
W Pracowni są wykonywane unikatowe badania diagnostyczne sferocytozy wrodzonej, hemoglobinopatii, talasemii, nocnej napadowej hemoglobinurii oraz wrodzonych niedokrwistości dyserytropoetycznych. We współpracy z Pracownią Immunopatologii Ciąży wykonuje się również badania przecieku płodowo-matczynego oraz ocenę materiału uzyskanego na drodze kordocentezy metoda cytometrii przepływowej.

Badania wykonywane w Pracowni Niedokrwistości Uwarunkowanych Genetycznie podano w poniższej tabeli.

\begin{tabular}{|c|c|c|c|c|}
\hline Rodzaj badania & $\begin{array}{l}\text { Materiał: antykoa- } \\
\text { gulant/objętość }\end{array}$ & $\begin{array}{l}\text { Maksymalny czas } \\
\text { przechowywania } \\
\text { i transportu mate- } \\
\text { riału do momentu } \\
\text { wykonania badania }\end{array}$ & $\begin{array}{l}\text { Przybliżony czas } \\
\text { oczekiwania na } \\
\text { wynik od momentu } \\
\text { otrzymania mate- } \\
\text { riału przez labora- } \\
\text { torium }\end{array}$ & $\begin{array}{l}\text { Zakres referen- } \\
\text { cyjny }\end{array}$ \\
\hline $\begin{array}{l}\text { Testy lateksowe } \\
\text { 1) białko ostrej fazy, białko C-reak- } \\
\text { tywne, test CRP (ocena ilościowa) } \\
\text { 2) Przeciwciała przeciwjądrowe, test } \\
\text { SLE (ocena jakościowa) } \\
\text { 3) czynnik reumatoidalny, test RF } \\
\text { (ocena ilościowa) } \\
\text { 4) czynnik reumatoidalny, test Wa- } \\
\text { alera-Rosego (ocena jakościowa) } \\
\text { 5) przeciwciała heterofilne, test } \\
\text { w kierunku mononukleozy zakaź- } \\
\text { nej (ocena jakościowa) }\end{array}$ & $\begin{array}{l}\text { Krew na skrzep } \\
\text { (wystarczy pobranie } \\
\text { jednej porcji krwi: } \\
4,5 \mathrm{ml} \text { ) }\end{array}$ & $\begin{array}{l}\text { 1) } 7 \mathrm{dni} \\
\text { 2) } 3 \mathrm{dni} \\
\text { 3) } 7 \mathrm{dni} \\
\text { 4) } 2 \mathrm{dni} \\
\text { 5) } 8 \mathrm{dni}\end{array}$ & $3 \mathrm{dni}$ & $\begin{array}{l}\text { 1) }<6 \mathrm{mg} / \mathrm{l} \\
\text { 2) Wynik ujemny } \\
\text { 3) } \leq 8 \mathrm{jm} . / \mathrm{ml} \\
\text { 4) Wynik ujemny } \\
\text { 5) Wynik ujemny }\end{array}$ \\
\hline Stężenie haptoglobin (metoda RID) & $\begin{array}{l}\text { Krew na skrzep } \\
4,5 \mathrm{ml}\end{array}$ & $8 \mathrm{dni}$ & $3 \mathrm{dni}$ & $0,45-2,4 \mathrm{~g} / \mathrm{l}$ \\
\hline $\begin{array}{l}\text { W kierunku sferocytozy wrodzo- } \\
\text { nej i innych membranopatii } \\
\text { Test EMA - badanie przesiewowe } \\
\text { metodą cytometrii przepływowej }\end{array}$ & $\begin{array}{l}\text { Krew pełna (EDTA) } \\
2 \mathrm{ml}\end{array}$ & $5 \mathrm{dni}$ & $\begin{array}{l}\text { Do 2-3 dni robo- } \\
\text { czych }\end{array}$ & $\begin{array}{l}\text { Ustalany dla każ- } \\
\text { dego badania }\end{array}$ \\
\hline $\begin{array}{l}\text { W kierunku talasemii i hemoglo- } \\
\text { binopatii } \\
\text { 1) } \mathrm{HbA}_{2} \text { metodą kolumienkową } \\
\text { 2) hemoglobina płodowa (HbF) }\end{array}$ & $\begin{array}{l}\text { Krew pełna (EDTA) } \\
2 \mathrm{ml}\end{array}$ & $5 \mathrm{dni}$ & $\begin{array}{l}\text { 1) Do } 5 \mathrm{dni} \\
\text { 2) Do } 5 \mathrm{dni}\end{array}$ & $\begin{array}{l}\text { 1) } 1,9-3,5 \% \\
\text { (dorośli i dzieci } \\
>8 . \mathrm{mż} \text {.) } \\
\text { 2) Do } 2 \% \text { (dorośli } \\
\text { i dzieci > 2. rż.) }\end{array}$ \\
\hline $\begin{array}{l}\text { 3) hemoglobiny patologiczne me- } \\
\text { todą elektroforezy w żelu agaro- } \\
\text { zowym }\end{array}$ & & & 3) Do 14 dni & $\begin{array}{l}\text { 3) Ocena jakoś- } \\
\text { ciowa }\end{array}$ \\
\hline
\end{tabular}




\begin{tabular}{|c|c|c|c|c|}
\hline Rodzaj badania & $\begin{array}{l}\text { Materiał: antykoa- } \\
\text { gulant/objętość }\end{array}$ & $\begin{array}{l}\text { Maksymalny czas } \\
\text { przechowywania } \\
\text { i transportu mate- } \\
\text { riału do momentu } \\
\text { wykonania badania }\end{array}$ & $\begin{array}{l}\text { Przybliżony czas } \\
\text { oczekiwania na } \\
\text { wynik od momentu } \\
\text { otrzymania mate- } \\
\text { riału przez labora- } \\
\text { torium }\end{array}$ & $\begin{array}{l}\text { Zakres referen- } \\
\text { cyjny }\end{array}$ \\
\hline $\begin{array}{l}\text { W kierunku enzymopatii krwinki } \\
\text { czerwonej metodami spektrofoto- } \\
\text { metrycznymi } \\
\text { 1) dehydrogenaza glukozo-6-fosfo- } \\
\text { ranowa } \\
\text { 2) kinaza pirogronianowa } \\
\text { 3) izomeraza glukozofosforanowa } \\
\text { 4) heksokinaza } \\
\text { 5) fosfofruktokinaza } \\
\text { 6) aldolaza } \\
\text { 7) kinaza fosfoglicerynianowa } \\
\text { 8) reduktaza methemoglobiny }\end{array}$ & $\begin{array}{l}\text { Krew pełna (EDTA) } \\
5 \mathrm{ml}\end{array}$ & $\begin{array}{l}\text { Do } 20 \text { dni, wyjątek: } \\
\text { PFK do } 6 \text { dni }\end{array}$ & Do 20 dni & $\begin{array}{l}\text { Hemoglobina } \\
\text { [jm./g] } \\
\text { 1) } 11,90-20,96 \\
\text { 2) } 9,08-23,76 \\
\text { 3) } 21,07-36,57 \\
\text { 4) } 1,03-2,45 \\
\text { 5) } 7,38-16,32 \\
\text { 6) } 2,29-5,37 \\
\text { 7) } 229,5-458,5 \\
\text { 8) } 18,48-38,78\end{array}$ \\
\hline $\begin{array}{l}\text { W kierunku nocnej napadowej he- } \\
\text { moglobinurii metodą cytometrii } \\
\text { przepływowej } \\
\text { 1) test FLAER - badanie przesie- } \\
\text { wowe } \\
\text { 2) ultraczułe badanie leukocytów: } \\
\text { - granulocyty } \\
\text { - monocyty } \\
\text { 3) ultraczułe badanie: CD59 erytro- } \\
\text { cytów }\end{array}$ & $\begin{array}{l}\text { Krew pełna (EDTA) } \\
5-10 \mathrm{ml}\end{array}$ & $\begin{array}{l}\text { Badania wykonuje } \\
\text { się od poniedziałku } \\
\text { do czwartku; ba- } \\
\text { dania 1) i 2) należy } \\
\text { wykonać w ciągu } 48 \\
\text { h od pobrania, bada- } \\
\text { nie 3) }-5 \text { dni }\end{array}$ & 2-3 dni robocze & $\begin{array}{l}\text { Odsetek komó- } \\
\text { rek GPI-ujem- } \\
\text { nych (\%) } \\
\text { 1) } 0,00-0,09 \\
\begin{array}{l}\text { 2) } \\
\cdot 0,00 \\
\cdot 0,00-0,02 \\
\text { 3) } 0,00-0,03\end{array}\end{array}$ \\
\hline $\begin{array}{l}\text { W kierunku niedokrwistości dyse- } \\
\text { rytropoetycznej typu II } \\
\text { Glikosfingolipidy erytrocytów - test } \\
\text { przesiewowy metodą chromatogra- } \\
\text { fii cienkowarstwowej }\end{array}$ & $\begin{array}{l}\text { Krew pełna (EDTA) } \\
5 \mathrm{ml}\end{array}$ & 5 dni od pobrania & $21 \mathrm{dni}$ & $\begin{array}{l}\text { Ocena jakościo- } \\
\text { wa }\end{array}$ \\
\hline $\begin{array}{l}\text { W kierunku przecieku płodowo- } \\
\text {-matczynego } \\
\text { Krwinki płodowe }(\mathrm{HbF}+) \text { ilościowo } \\
\text { metodą cytometrii przepływowej }\end{array}$ & $\begin{array}{l}\text { Krew pełna (EDTA) } \\
2 \mathrm{ml}\end{array}$ & $\begin{array}{l}5 \text { dni } \\
\text { W przypadku kon- } \\
\text { fliktu serologicznego } \\
\text { matczyno-płodo- } \\
\text { wego wskazane } \\
\text { wykonanie badania } \\
\text { w ciągu } 24-48 \text { h od } \\
\text { pobrania próbki krwi } \\
\text { U kobiety po poro- } \\
\text { dzie zaleca się po- } \\
\text { branie krwi matki do } \\
2 \text { h od porodu, ale } \\
\geq 15 \text { min po odkleje- } \\
\text { niu łożyska }\end{array}$ & $1-2$ dni & $\begin{array}{l}0,00-0,04 \% \text { ery- } \\
\text { trocytów z wyso- } \\
\text { ką ekspresją HbF }\end{array}$ \\
\hline $\begin{array}{l}\text { Ocena materiału z kordocentezy } \\
\text { Krwinki płodowe (HbF+) ilościowo } \\
\text { metodą cytometrii przepływowej }\end{array}$ & $\begin{array}{l}\text { Krew pełna (EDTA) } \\
0,5 \mathrm{ml}\end{array}$ & $1-3 \mathrm{dni}$ & $1-2 \mathrm{dni}$ & Brak normy \\
\hline
\end{tabular}




\section{Pracownia Grup Krwi i Prób Zgodności}

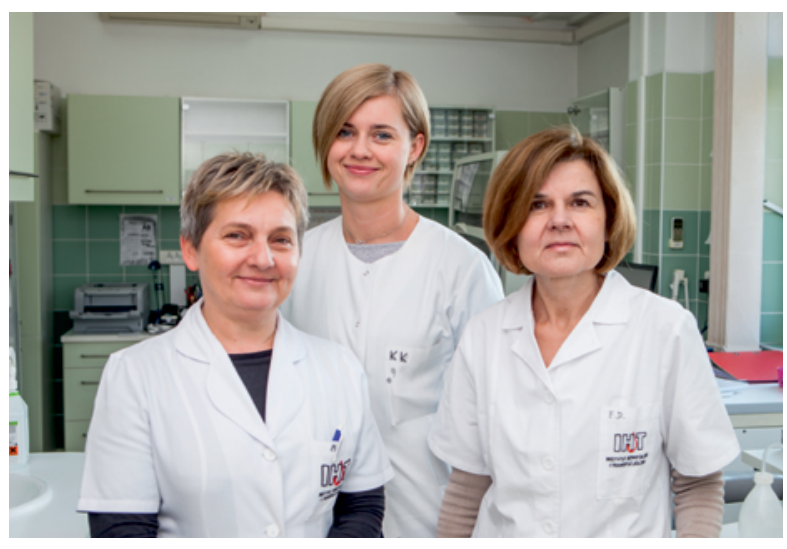

Kierownik: mgr Beata Wojciechowska

Zespół: mgr Katarzyna Kuziora, mgr Justyna Pastuszka, st. tech. Ewa Dudnikow

Adres: ul. Indiry Gandhi 14, 02-776 Warszawa tel.: 223496 383; 223496 404; 223496570 e-mail: bwojciechowska@ihit.waw.pl
W Pracowni są wykonywane wszystkie badania przedtransfuzyjne, w tym oznaczanie grupy krwi, próby zgodności, dobieranie krwi dla biorców $\mathrm{z}$ alloprzeciwciałami lub/i autoprzeciwciałami, a także badania ukierunkowane na wykrywanie i identyfikację przeciwciał odpornościowych oraz oznaczanie fenotypu erytrocytów.

Badania wykonywane w Pracowni Grup Krwi i Prób Zgodności podano w poniższej tabeli.

\begin{tabular}{|l|l|l|l|}
\hline Nazwa badania & Metoda/technika & Materiał* & $\begin{array}{l}\text { Wartości referen- } \\
\text { cyjne }\end{array}$ \\
\hline $\begin{array}{l}\text { Oznaczanie grupy krwi ABO } \\
\text { i RhD }\end{array}$ & $\begin{array}{l}\text { Technika mikrokolumnowa automatyczna lub ma- } \\
\text { nualna albo technika probówkowa }\end{array}$ & $\begin{array}{l}\text { Krew pełna } \\
\text { (EDTA) } 5 \text { ml }\end{array}$ & $\begin{array}{l}\text { Aglutynacja krwinek/ } \\
\text { /brak aglutynacji }\end{array}$ \\
\hline $\begin{array}{l}\text { Oznaczanie fenotypu w ukła- } \\
\text { dzie Rh i antygenie K }\end{array}$ & $\begin{array}{l}\text { Technika mikrokolumnowa automatyczna lub ma- } \\
\text { nualna albo technika probówkowa }\end{array}$ & $\begin{array}{l}\text { Krew pełna } \\
\text { (EDTA) } 5 \text { ml }\end{array}$ & $\begin{array}{l}\text { Aglutynacja krwinek/ } \\
\text { /brak aglutynacji }\end{array}$ \\
\hline $\begin{array}{l}\text { Oznaczanie fenotypu innych } \\
\text { klinicznie istotnych układów } \\
\text { grupowych }\end{array}$ & $\begin{array}{l}\text { Technika mikrokolumnowa automatyczna lub ma- } \\
\text { nualna albo technika probówkowa }\end{array}$ & $\begin{array}{l}\text { Krew pełna } \\
\text { (EDTA) } 5 \text { ml }\end{array}$ & $\begin{array}{l}\text { Aglutynacja krwinek/ } \\
\text { /brak aglutynacji }\end{array}$ \\
\hline Identyfikacja przeciwciał & $\begin{array}{l}\text { Technika mikrokolumnowa automatyczna lub ma- } \\
\text { nualna albo technika probówkowa }\end{array}$ & $\begin{array}{l}\text { Krew pełna } \\
\text { (EDTA) } 5 \text { ml }\end{array}$ & $\begin{array}{l}\text { Aglutynacja krwinek/ } \\
\text { /brak aglutynacji }\end{array}$ \\
\hline Identyfikacja przeciwciał & $\begin{array}{l}\text { Technika mikrokolumnowa automatyczna lub ma- } \\
\text { nualna albo technika probówkowa }\end{array}$ & $\begin{array}{l}\text { Krew pełna } \\
\text { (EDTA) } 5 \text { ml }\end{array}$ & $\begin{array}{l}\text { Aglutynacja krwinek/ } \\
\text { /brak aglutynacji }\end{array}$ \\
\hline Próba zgodności serologicznej & $\begin{array}{l}\text { Technika mikrokolumnowa automatyczna lub ma- } \\
\text { nualna albo technika probówkowa }\end{array}$ & $\begin{array}{l}\text { Krew pełna } \\
\text { (EDTA) } 5 \text { ml }\end{array}$ & $\begin{array}{l}\text { Aglutynacja krwinek/ } \\
\text { /brak aglutynacji }\end{array}$ \\
\hline $\begin{array}{l}\text { Dobieranie krwi dla pacjentów } \\
\text { z auto-/alloprzeciwciałami }\end{array}$ & $\begin{array}{l}\text { Technika mikrokolumnowa automatyczna lub ma- } \\
\text { nualna albo technika probówkowa }\end{array}$ & $\begin{array}{l}\text { Krew pełna } \\
\text { (EDTA) } 5 \text { ml }\end{array}$ & $\begin{array}{l}\text { Aglutynacja krwinek/ } \\
\text { /brak aglutynacji }\end{array}$ \\
\hline Kontrola serologiczna & $\begin{array}{l}\text { Technika mikrokolumnowa automatyczna lub ma- } \\
\text { nualna albo technika probówkowa }\end{array}$ & $\begin{array}{l}\text { Krew pełna } \\
\text { (EDTA) } 5 \text { ml }\end{array}$ & $\begin{array}{l}\text { Aglutynacja krwinek/ } \\
\text { /brak aglutynacji }\end{array}$ \\
\hline
\end{tabular}

*W przypadku badań wykonywanych metodą manualną, techniką mikrokolumnową lub probówkową dopuszcza się pobranie krwi na skrzep 


\section{Pracownia Genetyki Komórek Krwi i Chimeryzmu}

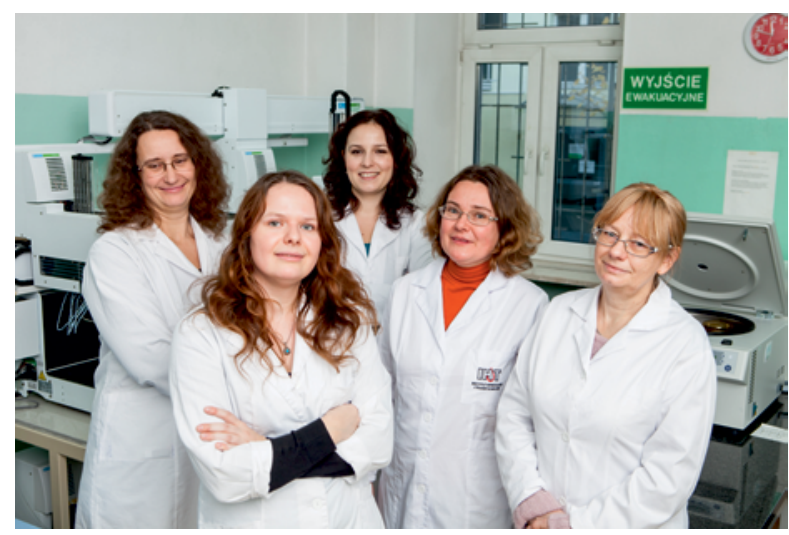

Kierownik: dr n. biol. Katarzyna Guz

Zespół: dr n. przyr. Agnieszka Orzińska, mgr Justyna Smolarczyk-Wodzyńska, mgr Magdalena Krzemieniowska, mgr Anna Kiszło, mgr Joanna Skulimowska, mgr Sylwia Purchla-Szepioła

Adres: ul. Chocimska 5, budynek B, 00-957 Warszawa tel.: 223496 630; 223496 637; 223496649

e-mail:kguz@ihit.waw.pl

W Pracowni są prowadzone unikatowe w skali kraju, wysokospecjalistyczne badania genotypowania antygenów komórek krwi oraz badania chimeryzmu poprzeszczepowego. Badania genotypowania antygenów komórek krwi dotyczą antygenów krwinek płytkowych, krwinek czerwonych i granulocytów i są prowadzone $\mathrm{w}$ ramach diagnostyki konfliktów matczyno-płodowych oraz analiz auto- i alloimmunizacji u chorych. W odniesieniu do badań genetycznych antygenów krwinek czerwonych na szczególne podkreślenie zasługuje wprowadzenie do praktyki nieinwazyjnej prenatalnej diagnostyki molekular- nej antygenów $\mathrm{RhD}$, c, E i K płodu, wykrywanych $\mathrm{w}$ osoczu kobiety w ciąży w płodowym DNA.

Do badań wykonywanych w Pracowni Genetyki Komórek Krwi i Chimeryzmu należą:

1) diagnostyka genetyczna konfliktów matczyno-płodowych w zakresie antygenów płytek krwi, granulocytów i erytrocytów:

- genotypowanie RHD płodu z krwi matki w celu kwalifikacji do immunoprofilaktyki w okresie ciąży. Nieinwazyjne genotypowanie genu $R H D$ płodu w celu kwalifikacji do immunoprofilaktyki konfliktu $\mathrm{RhD}$ wykonuje się u kobiet $\mathrm{RhD}$-ujemnych między 12. a 27. tygodniem ciąży (preferowane w 21.-26 tyg. ciąży) przy braku przeciwciał odpornościowych anty-D w 12 . i/lub 20. tygodniu ciąży. W przypadku płodów $R H D$-dodatnich ostatecznym kryterium kwalifikującym do otrzymania preparatu immunoglobuliny anty-D w 29.-30 tygodniu ciąży (zalecany termin podania preparatu) jest brak przeciwciał anty-D równiez w 28. tygodniu ciąży,

- genotypowanie $R H D$ i/lub alleli $R H C E^{*} \mathrm{c}$, ${ }^{*} \mathrm{c}$, ${ }^{*} \mathrm{E}$ płodu $\mathrm{z}$ krwi matek $\mathrm{z}$ przeciwcialami anty-D, anty-C, anty-c lub anty-E. Diagnostyka nieinwazyjna płodu $z$ krwi matek $z$ przeciwciałami do krwinek czerwonych jest zalecana w II trymestrze ciąży (od 15.-16. tyg. ciąży). Pozwala uniknąć inwazyjnych metod określania grupy krwi u płodów z ujemnym wynikiem genotypowania).

\begin{tabular}{|l|l|l|}
\hline Oznaczenie & Metoda/y & Wartości referencyjne \\
\hline $\begin{array}{l}\text { Genotypowanie } R H D \text { płodu z krwi matki w celu kwalifikacji do } \\
\text { immunoprofilaktyki w ciąży (tryb cito - oczekiwanie na wynik } \\
1 \text { tydzień) }\end{array}$ & RQ-PCR & $\begin{array}{l}\text { Genotyp określany wg wzorca kontrol- } \\
\text { nego DNA od osoby RHD+ (5geq/PCR) } \\
\text { i ujemnej kontroli }\end{array}$ \\
\hline $\begin{array}{l}\text { Genotypowanie RHD płodu z krwi matki w celu kwalifikacji do } \\
\text { immunoprofilaktyki w ciąży (skala 16 osób; oczekiwanie na wy- } \\
\text { nik } 1 \text { miesiąc lub } 1 \text { tydzień, jeśli do badań przesłano 16 próbek) }\end{array}$ & RQ-PCR & $\begin{array}{l}\text { Genotyp określany wg wzorca kontrol- } \\
\text { nego DNA od osoby RHD+ (5geq/PCR) } \\
\text { i ujemnej kontroli }\end{array}$ \\
\hline
\end{tabular}




\begin{tabular}{|l|l|l|}
\hline Oznaczenie & Metoda & Wartości referencyjne \\
\hline $\begin{array}{l}\text { Genotypowanie } R H D \text { płodu z krwi } \\
\text { matki z przeciwciałami anty-D }\end{array}$ & RQ-PCR & $\begin{array}{l}\text { Genotyp wg wzorca DNA RHD+, SRY+ (5geq/PCR) i ujemnej kontroli; } \\
\text { szukanie markera ojcowskiego ins/del dla ujemnych płodów żeńskich }\end{array}$ \\
\hline $\begin{array}{l}\text { Genotypowanie } R H C E^{*} \text { C płodu } \\
\text { z krwi matki z przeciwciałami } \\
\text { anty-C }\end{array}$ & RQ-PCR & $\begin{array}{l}\text { Genotyp wg wzorca DNA RHCE*c+, SRY+ (5geq/PCR) i ujemnej kontroli; } \\
\text { szukanie markera ojcowskiego ins/del dla ujemnych płodów żeńskich }\end{array}$ \\
\hline $\begin{array}{l}\text { Genotypowanie } R H C E^{*} E \text { płodu } \\
\text { z krwi matki z przeciwciałami } \\
\text { anty-E }\end{array}$ & RQ-PCR & $\begin{array}{l}\text { Genotyp wg wzorca DNA RHCE*E+, SRY+ (5geq/PCR) i ujemnej kontroli; } \\
\text { szukanie markera ojcowskiego ins/del dla ujemnych płodów żeńskich }\end{array}$ \\
\hline $\begin{array}{l}\text { Genotypowanie } R H D+R H C E^{*} C ; \\
* C \text { lub *E płodu z krwi matki } \\
\text { z przeciwciałami anty-D+ anty-C, } \\
-c \text { lub -E }\end{array}$ & RQ-PCR & $\begin{array}{l}\text { Genotyp wg wzorca DNA RHD+, SRY+ oraz RHCE*C+, RHCE*C+ lub } \\
\text { RHCE*E+, (5geq/PCR) i ujemnej kontroli; szukanie markera ojcowskiego } \\
\text { ins/del dla ujemnych płodów żeńskich }\end{array}$ \\
\hline
\end{tabular}

- ustalanie genotypu antygenów płodu z płynu owodniowego. Badania zalecane $\mathrm{u}$ kobiet $z$ przeciwciałami, poddawanych amniocen- tezie, w tym $z$ innych wskazań klinicznych lub jako mniej inwazyjna procedura pozyskania materiału płodu niż kordocenteza,

\begin{tabular}{|l|l|l|}
\hline Oznaczenie & Metoda/y & Wartości referencyjne \\
\hline $\begin{array}{l}\text { Genotypowanie antygenów K/k; Jka/Jkb; } \\
\text { Fya/Fyb; M/N lub S/s płodu z płynu owo- } \\
\text { dniowego }\end{array}$ & RQ-PCR & $\begin{array}{l}\text { Genotyp wg wzorca DNA homozygot w każdym antygenie } \\
\text { oraz ujemnej kontroli }\end{array}$ \\
\hline $\begin{array}{l}\text { Genotypowanie antygenów RhD, C/c lub } \\
\text { E/e płodu z płynu owodniowego }\end{array}$ & RQ-PCR & $\begin{array}{l}\text { Genotyp wg wzorca DNA RHD+ lub homozygot w antyge- } \\
\text { nach genu RHCE oraz ujemnej kontroli }\end{array}$ \\
\hline
\end{tabular}

- ustalanie niezgodności antygenowej na podstawie badania genotypu matki i ojca lub matki i płodu/noworodka. Badania praktykowane w diagnostyce konfliktów matczyno-płodowych w zakresie antygenów płytek krwi i granulocytów przy podejrzeniu alloimmunologicznej mało- płytkowości płodu/noworodka lub granulocytopenii noworodka jako metoda umożliwiająca dochodzenie swoistości przeciwcial poprzez wykrycie/wykluczenie niezgodności antygenowej rodziców czy matki i dziecka w klinicznie najistotniejszych układach HPA/HNA;

\begin{tabular}{|l|l|l|}
\hline Oznaczenie & Metoda & Wartości referencyjne \\
\hline Genotypowanie antygenów HPA-1 w konflikcie płytkowym & RQ-PCR & Genotyp wg wzorca z instrukcji producenta testu \\
\hline $\begin{array}{l}\text { Genotypowanie antygenów HPA-1;2;3;4;5;15 w konflikcie } \\
\text { płytkowym }\end{array}$ & RQ-PCR & Genotyp wg wzorca z instrukcji producenta testu \\
\hline $\begin{array}{l}\text { Genotypowanie antygenów HNA-1;3;4;5 w konflikcie gra- } \\
\text { nulocytarnym }\end{array}$ & PCR-SSP & Genotyp wg wzorca z instrukcji producenta testu \\
\hline $\begin{array}{l}\text { Genotypowanie antygenów HNA-3 lub -5 w konflikcie gra- } \\
\text { nulocytarnym }\end{array}$ & RQ-PCR & $\begin{array}{l}\text { Genotyp wg DNA od osób HNA-3,-5 a/a i HNA-3,-5 } \\
\text { b/b wobec ujemnej kontroli }\end{array}$ \\
\hline $\begin{array}{l}\text { Weryfikacja genetyczna fenotypu HPA-1a-ujemnego z ba- } \\
\text { dania przesiewowego metodą FACS }\end{array}$ & RQ-PCR & $\begin{array}{l}\text { Genotyp wg DNA od osób HPA-1 a/a i HPA-1b/b } \\
\text { wobec ujemnej kontroli }\end{array}$ \\
\hline $\begin{array}{l}\text { Oznaczenie allelu DRB3*0101 u osób HPA-1a-ujemnych } \\
\text { (predyspozycja wytwarzania przeciwciał anty-HPA-1a) }\end{array}$ & RQ-PCR & $\begin{array}{l}\text { Genotyp wg DNA od osób DRB3*0101(+) i *0101(-) } \\
\text { wobec ujemnej kontroli }\end{array}$ \\
\hline
\end{tabular}

2) genotypowanie antygenów erytrocytów po transfuzjach/przeszczepieniach allo-HSCT/organów ułatwiające oznaczenie antygenów i identyfikację alloprzeciwciał u pacjentów:

- $\quad z$ problemami w określeniu fenotypu krwinek czerwonych $z$ powodu wielkokrotnych transfuzji lub przeszczepienia allo-HSCT (w czasie $<3$ miesięcy),
- $\quad$ z obecnością allo- i autoprzeciwciał - między innymi u chorych $z$ niedokrwistością autoimmunologiczną,

- $\quad z$ podejrzeniem obecności przeciwcial do powszechnego/rzadkiego antygenu,

- $\quad z$ rozbieżnymi wynikami typowania serologicznego (warianty antygenu $\mathrm{D}, \mathrm{ABO}$ ); 


\begin{tabular}{|l|l|l|}
\hline Oznaczenie & Metoda & Wartości referencyjne \\
\hline $\begin{array}{l}\text { Oznaczenie genotypu antygenów RhD; C/c; E/e; K/k; Jka/Jkb; Fya/ } \\
\text { /Fyb; M/N; S/s; Doa/Dob erytrocytów (komplet) }\end{array}$ & RQ-PCR & $\begin{array}{l}\text { Genotyp wg wzorca z instrukcji producenta } \\
\text { testu }\end{array}$ \\
\hline $\begin{array}{l}\text { Oznaczenie genotypu antygenów k/K; Jka/Jkb; Fya/Fyb erytrocy- } \\
\text { tów }\end{array}$ & RQ-PCR & $\begin{array}{l}\text { Genotyp wg wzorca z instrukcji producenta } \\
\text { testu }\end{array}$ \\
\hline $\begin{array}{l}\text { Oznaczenie genotypu powszechnych/rzadkich antygenów ery- } \\
\text { trocytów }\end{array}$ & RQ-PCR & $\begin{array}{l}\text { Genotyp wg wzorca z instrukcji producenta } \\
\text { testu }\end{array}$ \\
\hline Oznaczenie genotypu antygenów grupy ABO erytrocytów & RQ-PCR & $\begin{array}{l}\text { Genotyp wg wzorca z instrukcji producenta } \\
\text { testu }\end{array}$ \\
\hline $\begin{array}{l}\text { Oznaczenie genotypu antygenów RhD; C/c; E/e i wariantów D } \\
\text { częściowe erytrocytów }\end{array}$ & RQ-PCR & $\begin{array}{l}\text { Genotyp wg wzorca z instrukcji producenta } \\
\text { testu }\end{array}$ \\
\hline $\begin{array}{l}\text { Oznaczenie genotypu słabych odmian antygenu RhD erytrocy- } \\
\text { tów }\end{array}$ & RQ-PCR & $\begin{array}{l}\text { Genotyp wg wzorca z instrukcji producenta } \\
\text { testu }\end{array}$ \\
\hline $\begin{array}{l}\text { Oznaczenie wariantów DEL i fenotypów RhD-ujemnych erytro- } \\
\text { cytów }\end{array}$ & RQ-PCR & $\begin{array}{l}\text { Genotyp wg wzorca z instrukcji producenta } \\
\text { testu }\end{array}$ \\
\hline $\begin{array}{l}\text { Oznaczenie zygotyczności genu RHD } \\
\text { Rengotyczność wg wzorca DNA od osób } \\
\text { homo- i heterozygotycznych w RHD }\end{array}$ \\
\hline
\end{tabular}

3) genotypowanie antygenów HPA płytek krwi. Badania ułatwiające identyfikację swoistości przeciwciał przeciwpłytkowych anty-HPA u pacjentów ze skazą małopłytkową, opornością na przetaczane płytki lub małopłytkowością po allo-HSCT. Poznanie genotypu HPA umożliwia dobór dawców kkp-zgodnych w zakresie antygenów HPA;

\begin{tabular}{|l|l|l|}
\hline Oznaczenie & Metoda/y & Wartości referencyjne \\
\hline $\begin{array}{l}\text { Oznaczenie genotypu antygenów płytkowych } \\
\text { HPA-1 }\end{array}$ & RQ-PCR & $\begin{array}{l}\text { Genotyp wg wzorca z instrukcji producenta } \\
\text { testu }\end{array}$ \\
\hline $\begin{array}{l}\text { Oznaczenie genotypu antygenów płytkowych } \\
\text { HPA-1;2;3;4;5;15 }\end{array}$ & RQ-PCR & $\begin{array}{l}\text { Genotyp wg wzorca z instrukcji producenta } \\
\text { testu }\end{array}$ \\
\hline $\begin{array}{l}\text { Dobór dawców zgodnych w zakresie antygenów } \\
\text { płytkowych HPA i grupie ABO/Rh dla pacjenta } \\
\text { z przeciwciałami anty-HPA (z rejestru dawców } \\
\text { HPA/HNA) }\end{array}$ & $\begin{array}{l}\text { Przeszukiwanie rejestru } \\
\text { dawców HPA/HNA }\end{array}$ & \\
\hline $\begin{array}{l}\text { Genotypowanie antygenów płytkowych HPA-1 } \\
\text { w małopłytkowościach po transplantacji allo- } \\
- \text {-HSCT/organu (dawca/biorca) }\end{array}$ & RQ-PCR & $\begin{array}{l}\text { Genotyp wg wzorca z instrukcji producenta } \\
\text { testu }\end{array}$ \\
\hline $\begin{array}{l}\text { Genotypowanie antygenów płytkowych HPA-1; } \\
-2 ;-3 ;-4 ;-5 ;-15 \text { w małopłytkowościach po trans- } \\
\text { plantacji allo-HSCT/organu (dawca/biorca) }\end{array}$ & RQ-PCR & $\begin{array}{l}\text { Genotyp wg wzorca z instrukcji producenta } \\
\text { testu }\end{array}$ \\
\hline
\end{tabular}

4) genotypowanie antygenów HNA granulocytów. Badania ułatwiające identyfikację przeciwciał granulocytarnych anty-HNA u pacjentów $z$ podejrzeniem zespołu TRALI, granulocytopenii po allo-HSCT, odrzucaniem przeszczepu organu (m.in. nerki przy niezgodności w zakresie antygenów HNA-3);

\begin{tabular}{|l|l|l|}
\hline Oznaczenie & Metoda & Wartości referencyjne \\
\hline Oznaczenie genotypu antygenów HNA-1;3;4;5 granulocytów & PCR-SSP & Genotyp wg wzorca z instrukcji producenta testu \\
\hline $\begin{array}{l}\text { Oznaczenie genotypu antygenów HNA-3 lub HNA-5 granu- } \\
\text { locytów }\end{array}$ & RQ-PCR & $\begin{array}{l}\text { Genotyp wg wzorca k DNA od osób HNA-3;-5 } \\
\text { a/a i HNA-3;-5 b/b; ujemnej kontroli }\end{array}$ \\
\hline $\begin{array}{l}\text { Genotypowanie antygenów granulocytów HNA-1;-3;-4;-5 } \\
\text { w granulocytopeniach po transplantacji allo-HSCT/ } \\
\text { /organu (dawca/biorca) }\end{array}$ & PCR-SSP & Genotyp wg wzorca z instrukcji producenta testu \\
\hline $\begin{array}{l}\text { Genotypowanie antygenów granulocytów HNA-3 lub HNA- } \\
5 \text { w granulocytopeniach po transplantacji allo-HSCT/orga- } \\
\text { nu (dawca/biorca) }\end{array}$ & RQ-PCR & $\begin{array}{l}\text { Genotyp wg wzorca k DNA od osób HNA-3;-5 } \\
\text { a/a i HNA-3,-5 b/b; ujemnej kontroli }\end{array}$ \\
\hline
\end{tabular}


5) genotypowanie antygenów HPA płytek, HNA granulocytów i wybranych układów grupowych erytrocytów u krwiodawców. Oferta skierowa- na do CKiK-ów w celu tworzenia rejestrów dawców $z$ oznaczonymi antygenami HPA; HNA i wybranymi antygenami erytrocytów;

\begin{tabular}{|l|l|l|}
\hline Oznaczenie & Metoda & Wartości referencyjne \\
\hline $\begin{array}{l}\text { Oznaczenie genotypu jednego układu antygenów płytek } \\
\text { (HPA-1,2,3,5,15); granulocytów (HNA-3;-5) lub erytrocytów } \\
\text { (K/k; Jka/Jkb; Fya/Fyb; M/N; S/s) - przy skali 7 osób }\end{array}$ & RQ-PCR & $\begin{array}{l}\text { Genotyp wg wzorca DNA od osób a/a i b/b } \\
\text { w badanym układzie oraz ujemnej kontroli }\end{array}$ \\
\hline $\begin{array}{l}\text { Oznaczenie genotypu jednego układu antygenów płytek } \\
\text { (HPA-1,2,3,5,15); granulocytów (HNA-3;-5) lub erytrocytów } \\
\text { (K/k; Fya/Fyb; Jka/Jkb; M/N; S/s) przy skali 90 osób }\end{array}$ & RQ-PCR & $\begin{array}{l}\text { Genotyp wg wzorca DNA od osób a/a i b/b } \\
\text { w badanym układzie oraz ujemnej kontroli }\end{array}$ \\
\hline $\begin{array}{l}\text { Oznaczenie genotypu w 4 układach antygenów płytek (HPA- } \\
\begin{array}{l}1,2,3,5,15) ; \text { granulocytów (HNA-3;-5) lub erytocytów (K/k; } \\
\text { Jka/Jkb; Fya/Fyb; M/N; S/s) przy skali 19 osób }\end{array}\end{array}$ & RQ-PCR & $\begin{array}{l}\text { Genotyp wg wzorca DNA od osób a/a i b/b } \\
\text { w badanych układach oraz ujemnej kontroli }\end{array}$ \\
\hline $\begin{array}{l}\text { Wykrywanie genu RHD w pulach osocza dawców Rh-ujem- } \\
\text { nych przy skali 32 osób }\end{array}$ & RQ-PCR & $\begin{array}{l}\text { Genotyp wg wzorca DNA od osoby z prawidło- } \\
\text { wym genem RHD i ujemnej kontroli }\end{array}$ \\
\hline
\end{tabular}

6) badanie chimeryzmu po allo-HSCT - ustalanie genotypu markerów STR u dawcy i biorcy sprzed przeszczepienia HSC, ilościowa analiza chimeryzmu poprzez określenie udziału odsetkowego genotypu dawcy (proporcji markerów STR dawcy $v$. markerów STR biorcy) we krwi lub szpiku biorcy po allo-HSCT;

\begin{tabular}{|l|l|l|}
\hline Oznaczenie & Metoda & Wartości referencyjne \\
\hline $\begin{array}{l}\text { Oznaczenie chimeryzmu po allo-HSCT } \\
\text { metodą STR-PCR }\end{array}$ & STR-PCR & $\begin{array}{l}\text { Genotyp dawcy/biorcy; \% udziału genotypu dawcy wg wzorca z in- } \\
\text { strukcji producenta testu }\end{array}$ \\
\hline
\end{tabular}

7) analiza genetyczna mutacji $\mathrm{w}$ hemoglobinopatiach, w kierunku wykrywania podłoża genetycznego $\alpha$-i $\beta$-talasemii.

\begin{tabular}{|l|l|l|}
\hline Oznaczenie & Metoda/y & Wartości referencyjne \\
\hline $\begin{array}{l}\text { Badania genetyczne } \alpha \text {-talasemii } \\
\text { i hemoglobinopatii }- \text { badania } \\
\text { podstawowe }\end{array}$ & $\begin{array}{l}\text { Poszukiwanie mutacji delecyjnych me- } \\
\text { todą MLPA (zestaw komercyjny) oraz } \\
\text { gapPCR w klasterze genów } \alpha \text {-globiny }\end{array}$ & $\begin{array}{l}\text { Mutacje wg instrukcji producenta testu MLPA; } \\
\text { w gapPCR wg DNA z mutacjami delecyjnymi } \\
\text { w klasterze genów } \alpha \text {-globiny }\end{array}$ \\
\hline $\begin{array}{l}\text { Badania genetyczne } \alpha \text {-talasemii } \\
\text { i hemoglobinopatii }- \text { badania } \\
\text { uzupełniające }\end{array}$ & $\begin{array}{l}\text { Sekwencjonowanie genów HBA1 } \\
\text { i HBA2 } \alpha \text {-globiny }\end{array}$ & $\begin{array}{l}\text { Bezpośrednia analiza sekwencji genów HBA1 } \\
\text { i HBA2 } \alpha \text {-globiny względem sekwencji referen- } \\
\text { cyjnej }\end{array}$ \\
\hline $\begin{array}{l}\text { Badania genetyczne } \beta \text {-talasemii } \\
\text { i hemoglobinopatii }- \text { badania } \\
\text { podstawowe }\end{array}$ & $\begin{array}{l}\text { Wykrywanie delecji del619 bp oraz } \\
\text { sekwencjonowanie genu HBB } \beta \text {-globi- } \\
\text { ny (w tym HbS, HbC, HbE) }\end{array}$ & $\begin{array}{l}\text { Bezpośrednia analiza sekwencji genu HBB } \beta \text {-globi- } \\
\text { ny względem sekwencji referencyjnej }\end{array}$ \\
\hline $\begin{array}{l}\text { Badania genetyczne } \beta \text {-talasemii } \\
\text { i hemoglobinopatii }- \text { badania } \\
\text { uzupełniające }\end{array}$ & $\begin{array}{l}\text { Badania uzupełniające metodą MLPA } \\
\text { i/lub gapPCR i sekwencjonowanie } \\
\text { hybrydy } \lambda-\beta \text {-globiny (hemoglobina } \\
\text { Lepore) }\end{array}$ & $\begin{array}{l}\text { Mutacje wg instrukcji producenta testu MLPA; } \\
\text { w gapPCR wg DNA z mutacjami; bezpośrednia } \\
\text { analiza sekwencji hybrydy } \lambda-\beta \text {-globiny względem } \\
\text { sekwencji referencyjnej }\end{array}$ \\
\hline
\end{tabular}




\section{ZAKŁAD IMMUNOGENETYKI}

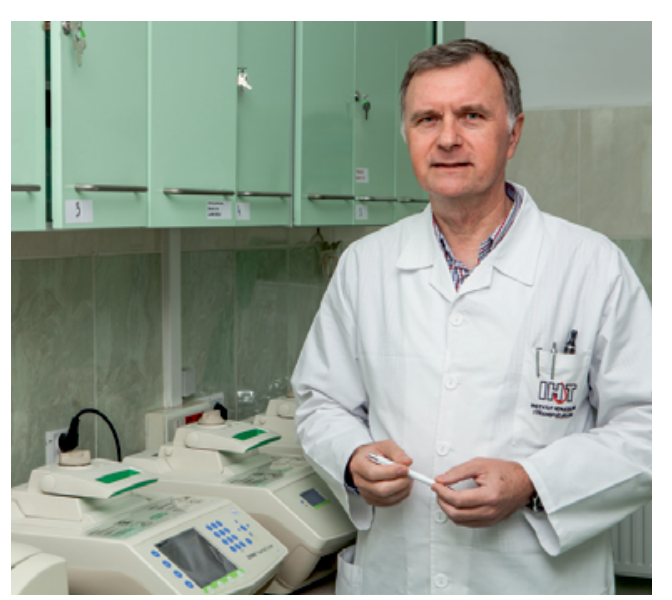

Kierownik: dr hab. n. med. Jacek Nowak, prof. nadzw.

Zastępca: dr n. med. Urszula Szlendak

Diagności laboratoryjni: mgr Joanna Dziopa, mgr Sławomir Gwozdowicz, mgr Elżbieta Graczyk-Pol, mgr Agnieszka Malinowska, mgr Anna Marosz-Rudnicka, mgr Renata Mika-Witkowska, mgr Klaudia Nestorowicz, mgr Daria Pawliczak, mgr Marta Rogatko-Koroś, mgr Agnieszka Witkowska, mgr Emilia Wojciechowska

Sekretariat: Agnieszka Gawron

Zakład prowadzi działalność usługową i naukową $\mathrm{w}$ dziedzinie immunogenetycznego typowania biorców i dawców do przeszczepienia HSC, a także

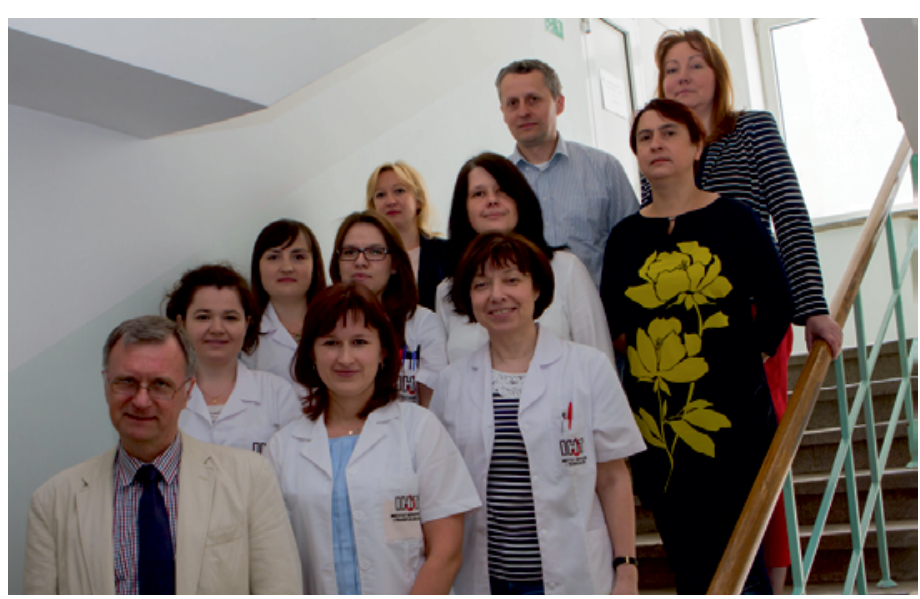

realizuje szkolenia oraz udziela konsultacji w tym zakresie. W ramach tych procedur Zakład prowadzi immunogenetyczny dobór niespokrewnionych, rodzinnych i haploidentycznych dawców HSC do transplantacji allogenicznych. Poszukuje również dawców w rejestrach krajowych i zagranicznych, ustala strategię doboru rodzinnego lub niespokrewnionego dawcy, wykonuje genotypowania HLA i KIR, a także udziela porad w zakresie immunogenetycznej selekcji optymalnego dawcy rodzinnego lub niespokrewnionego.

Działalność naukowa Zakładu koncentruje się na wypracowywaniu standardów immunogenetycz-

\begin{tabular}{|l|l|l|}
\hline Oznaczenie & Metoda & Zakres badań HLA \\
\hline $\begin{array}{l}\text { Wstępne typowanie HLA chorego i (ew.) członków jego rodzi- } \\
\text { ny do transplantacji HSC }\end{array}$ & $\begin{array}{l}\text { PCR-SSO } \\
\text { Luminex }\end{array}$ & $\begin{array}{l}\text { HLA-A, B, DRB1 na poziomie niskiej/pośred- } \\
\text { niej rozdzielczości }\end{array}$ \\
\hline $\begin{array}{l}\text { Weryfikacyjne typowanie HLA chorego i zgodnych członków } \\
\text { rodziny do transplantacji HSC }\end{array}$ & $\begin{array}{l}\text { PCR-SSO } \\
\text { Luminex }\end{array}$ & $\begin{array}{l}\text { HLA-A, C i DQB1 (lub B, C i DQB1) na pozio- } \\
\text { mie pośredniej/wyższej rozdzielczości }\end{array}$ \\
\hline $\begin{array}{l}\text { Weryfikacyjne typowanie HLA chorego i niespokrewnionego } \\
\text { dawcy szpiku }\end{array}$ & PCR-SSP & $\begin{array}{l}\text { HLA-A, B, C, DRB1 i DQB1 na poziomie wyso- } \\
\text { kiej i/lub niskiej rozdzielczości }\end{array}$ \\
\hline Wstępne typowanie HLA do doboru koncentratu płytkowego & $\begin{array}{l}\text { PCR-SSO } \\
\text { Luminex }\end{array}$ & $\begin{array}{l}\text { HLA-A, B na poziomie niskiej/pośredniej } \\
\text { rozdzielczości }\end{array}$ \\
\hline $\begin{array}{l}\text { Związek HLA z chorobami } \\
\text { Poszukiwany allel/antygen HLA }\end{array}$ & PCR-SSP & $\begin{array}{l}\text { HLA-A, B, C, DRB1 lub DQB1 na poziomie ni- } \\
\text { skiej lub wysokiej rozdzielczości }\end{array}$ \\
\hline $\begin{array}{l}\text { Badanie HLA niespokrewnionych dawców szpiku rekrutowa- } \\
\text { nych do rejestru }\end{array}$ & $\begin{array}{l}\text { PCR-SSO } \\
\text { Luminex }{ }^{\circledR}\end{array}$ & $\begin{array}{l}\text { HLA-A, B, C, DRB1, DQB1 na poziomie niskiej } \\
\text { rozdzielczości }\end{array}$ \\
\hline $\begin{array}{l}\text { Uzupełniające typowanie HLA niespokrewnionych dawców } \\
\text { szpiku z rejestru - } 1 \text { locus }\end{array}$ & PCR-SSP & $\begin{array}{l}\text { HLA-A, B, C, DRB1 lub DQB1 na poziomie wy- } \\
\text { sokiej i/lub niskiej rozdzielczości }\end{array}$ \\
\hline Genotypowanie KIR-SSP & PCR-SSP & $\begin{array}{l}\text { Określenie genotypu KIR na poziomie geno- } \\
\text { wym wraz z ekspertyzą }\end{array}$ \\
\hline Genotypowanie HLA-DPB1, wysoka rozdzielczość & PCR-SSP & HLA-DPB1 na poziomie wysokiej rozdzielczości \\
\hline
\end{tabular}

Adres: ul. Chocimska 5, 00-957 Warszawa

tel.: 223496 648; 602290529

faks 223496606

e-mail: szpik@ihit.waw.pl 
nego doboru dawcy, metodyce badań genetycznych oraz na badaniach $z$ zakresu genetyki populacyjnej i związku HLA $z$ wystapieniem i przebiegiem chorób. Istotnym kierunkiem działalności naukowej są również badania nad patogenezą nocnej napadowej hemoglobinurii.

Zakład prowadzi szkolenia przed- i podyplomowe w zakresie metodyki badania HLA oraz współorganizuje staże specjalizacyjne $z$ labora- toryjnej immunologii medycznej i transplantologii. Prowadzi także indywidualne szkolenia w ramach specjalizacji w dziedzinie hematologii, transplantologii, transfuzjologii i analityki medycznej, laboratoryjnej hematologii medycznej, immunologii medycznej, transfuzjologii medycznej i genetyki medycznej.

W skład Zakładu wchodzą Pracownia Zgodności Tkankowej i Pracownia Doboru Dawców Komórek Krwiotwórczych.

\section{Pracownia Zgodności Tkankowej}

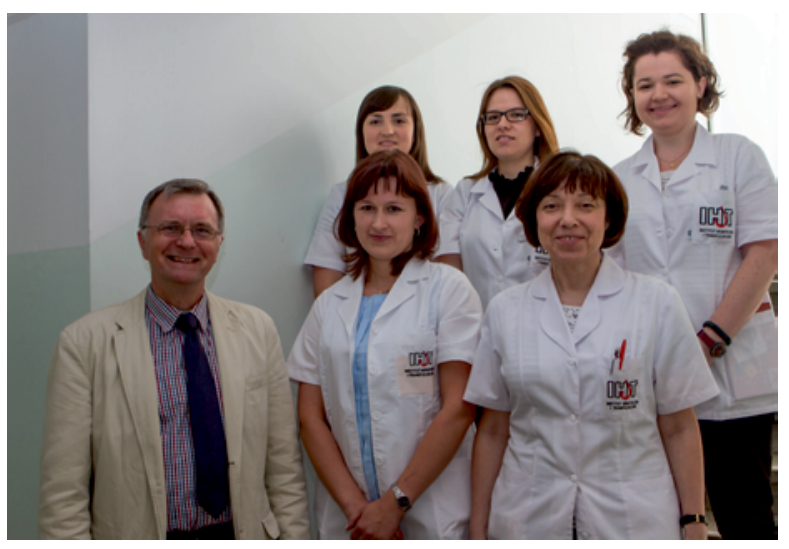

\section{Pracownia Doboru Dawców Komórek Krwiotwórczych}

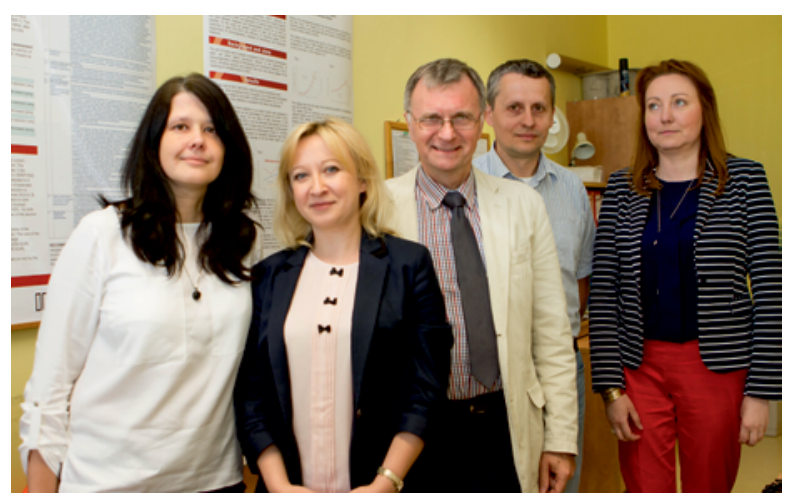

Kierownik: mgr Klaudia Nestorowicz

Adres: ul. Chocimska 5, 00-957 Warszawa tel. 223496623

Do zadań Pracowni należy dobór niespokrewnionych dawców HSC do transplantacji allogenicznych. Poszukiwania dawców są prowadzone w rejestrach krajowych i zagranicznych. W przypadkach braku w pełni zgodnego dawcy Zakład Immunogenetyki przedstawia propozycję optymalizacji doboru częściowo niezgodnego dawcy niespokrewnionego lub haploidentycznego dawcy rodzinnego. W tym celu w Pracowni wykonuje się dodatkowe badania,

\author{
Kierownik: mgr Renata Mika-Witkowska \\ Adres: ul. Chocimska 5, 00-957 Warszawa \\ tel.: $223496672 ; 223496659$
}

Do zakresu badań wykonywanych w Pracowni Zgodności Tkankowej należą badania antygenów zgodności tkankowej HLA i KIR wykonywane metodami PCR-SSP (sequence specific primers) i PCR-SSO Luminex ${ }^{\circledR}$ (sequence specific oligonucleotide probes Luminex ${ }^{\circledR}$ ). Materiałem do badań jest krew pełna pobrana na EDTA w objętości $4 \mathrm{ml} \mathrm{lub} 10 \mathrm{ml}$.

takie jak genotypowanie KIR lub HLA-DPB1. Badania te mogą wymagać ekspertyzy immunogenetycznej w zakresie selekcji optymalnego dawcy HSC.

Do zakresu badań wykonywanych w Pracowni należą:

1) genotypowanie KIR u dawców i biorców przeszczepu HSC wraz $z$ ekspertyzą polegającą na określeniu zawartości haplotypów KIR B oraz na predykcji zmian licencjonowania komórek NK dawcy w nowym środowisku HLA biorcy. Badanie może być wykorzystane w przypadkach przeszczepienia HSC od dawcy częściowo niezgodnego w zakresie HLA klasy I lub haploidentycznego. Badanie pozwala na precyzyjną ocenę konstelacji szerokich haplotypów KIR B oraz funkcjonalnych par HLA-KIR (receptor-ligand) u dawcy i zmian tych par, do jakich dochodzi u biorcy po transplantacji. Badanie umożliwia wyselekcjonowanie dawcy o wyższym potencjale przeciwnowotworowym ze strony komórek NK nie tylko poprzez określenie zawartości haplotypów KIR B, ale przede wszystkim poprzez predykcję zmian w poziomie licencjonowania komórek NK dawcy w nowym środowisku HLA biorcy. 
Do wyselekcjonowania lepszego dawcy służy wspomniana ekspertyza. Celem badania wraz z ekspertyzą jest wykorzystanie nowych możliwości poprawy szans na eradykację nowotworu u biorców $z$ nowotworami leczonych przeszczepieniem HSC;

2) genotypowanie HLA DPB1 w wysokiej rozdzielczności. Wdrożenie typowania dodatkowego locus HLA (DPB1) umożliwia ustalenie zgodności pary dawca-biorca w tym zakresie. Jest to szczególnie istotne w przypadkach doboru dawców częściowo niezgodnych w zakresie HLA lub haploidentycznych. W tych typach transplantacji HSC istotnego znaczenia nabiera obecność u biorcy przeciwciał anty-HLA (anty HLA-DP lub wieloswoistych). Dobór dawcy w zakresie HLA-DPB1 może zapobiec odrzuceniu przeszczepu u biorców immunizowanych.

\section{ZAKŁAD WIRUSOLOGII}

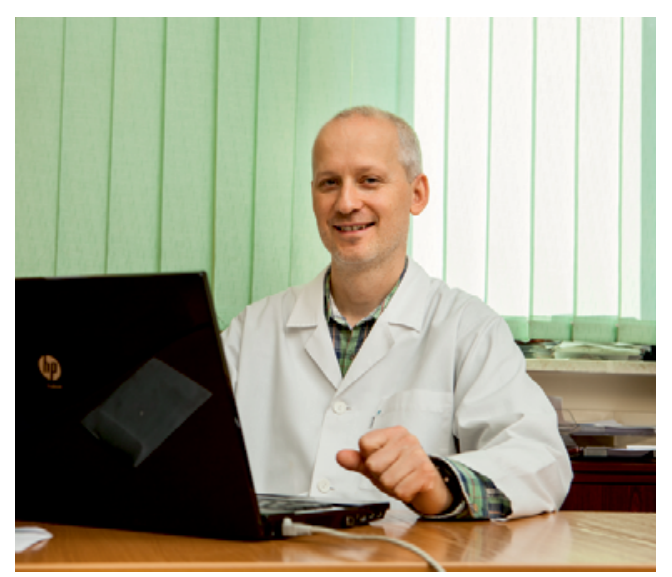

Kierownik: dr hab. n. med. Piotr Grabarczyk, prof. nadzw. Diagności laboratoryjni: mgr Paula Bryłka, mgr Aleksandra Kalińska, mgr Aneta Kopacz, mgr Dorota Kubicka-Russel, mgr Grzegorz Liszewski, mgr Ewa Noceń, mgr Anna Potępa, mgr Joanna Sierżęga, mgr Ewa Sulkowska, mgr Justyna Śledź, mgr Paulina Zwolińska

Biolodzy: Anna Chrzanowska

Pomoc laboratoryjna: Zofia Grzywacz

Sekretariat: mgr Katarzyna Tkaczuk

W Zakładzie Wirusologii są prowadzone prace naukowe oraz działalność usługowa, szkoleniowa i konsultacyjna $\mathrm{w}$ dziedzinie wirusologii medycznej, zwłaszcza w zakresie diagnostyki i epidemiologii wirusów ważnych dla bezpieczeństwa przetoczeń krwi, w tym wirusa zapalenia wątroby typu A (HAV), typu B (HBV), typu C (HCV), wirusa nabytego niedoboru odporności (HIV1/2), parvowirusa B19 (B19V), wirusa cytomegalii (CMV), wirusa Epstein-Barr (EBV) i wirusa BK (BKV). W Zakładzie są także diagnozowane zakażenia wywołane wirusem ludzkiej białaczki z komórek T

Adres: ul. Chocimska 5, 00-957 Warszawa

tel. 223496640

faks 223496603

e-mail: zakladwirusologii@ihit.waw.pl
(HTLV I/II) oraz zakażenia o etiologii innej niż wirusowa (kiła i toksoplazmoza).

Zakład Wirusologii prowadzi badania weryfikacyjne i uzupełniające dla wszystkich CKiK i pełni funkcje ośrodka referencyjnego w zakresie zakażeń wirusowych przenoszonych przez krew. W Zakładzie Wirusologii są także prowadzone badania związane z nowo pojawiającymi się czynnikami zakaźnymi, na przekład wirusem zapalenia wątroby typu E (HEV) czy wirusem zachodniego Nilu (WNV).

Działalność naukowa Zakładu wiąże się z profilem prowadzonej działalności diagnostycznej, w tym $z$ doskonaleniem metod detekcji/weryfikacji/diagnostyki zakażeń u dawców, analizą danych epidemiologicznych i badaniem polimorfizmów wirusów przenoszonych przez krew. Badania te obejmują wdrażanie i doskonalenie metod wykrywania, algorytmów monitorowania zakażeń wirusowych u chorych, różnicowanie zakażeń latentnych i aktywnych oraz ocenę skuteczności leczenia przeciwwirusowego. Prowadzone są również badania z zakresu epidemiologii molekularnej wirusów obejmujące identyfikację „mutantów ucieczki” i dróg ich przenoszenia.

Zakład prowadzi wykłady w ramach kursów CMKP dla diagnostów laboratoryjnych specjalizujących się w laboratoryjnej transfuzjologii medycznej, dla lekarzy specjalizujących się $\mathrm{w}$ transfuzjologii 
klinicznej i hematologii, a także kursy i szkolenia dla dyrektorów CKiK i konsultantów wojewódzkich $\mathrm{w}$ dziedzinie transfuzjologii.
W skład Zakładu wchodzą Pracownia Badań Weryfikacyjnych, Pracownia Wirusologii Klinicznej oraz Pracownia Kontroli Jakości i Analiz.

\section{Pracownia Badań Weryfikacyjnych}

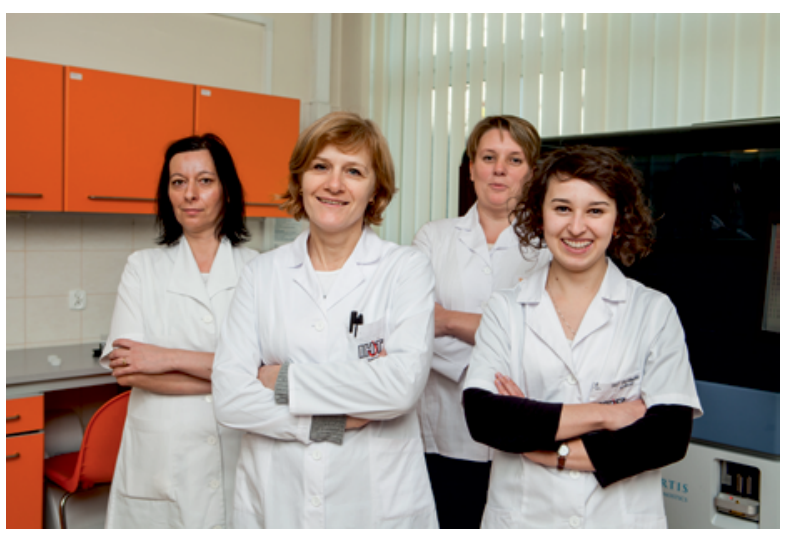

Kierownik: mgr Ewa Sulkowska

Zespół: mgr Anna Chrzanowska, mgr Ewa Noceń, mgr Justyna Śledź

Adres: Chocimska 5, 00-957 Warszawa

tel. 223496662

faks 223496603

e-mail: esulkowska@ihit.waw.pl

Badania wykonywane w Pracowni Badań Weryfikacyjnych wymieniono w poniższej tabeli.

\begin{tabular}{|l|l|l|l|}
\hline Oznaczenie & Metoda & Materiał & Wartości referencyjne \\
\hline Badanie jakościowe RNA HCV+ RNA HIV1/2+ DNA HBV & TMA & Osocze, surowica & Wynik ujemny \\
\hline Badanie jakościowe DNA HBV & Real-time PCR & Osocze & Wynik ujemny \\
\hline Badanie jakościowe RNA HCV & Real-time PCR & Osocze & Wynik ujemny \\
\hline Badanie jakościowe RNA HIV & Real-time PCR & Osocze & Wynik ujemny \\
\hline Badanie ilościowe DNA parvowirusa B19 & Real-time PCR & Osocze & Wynik ujemny \\
\hline Badanie WB w kierunku kiły & Western blot & Surowica, osocze & Wynik ujemny \\
\hline Test kiłowy TPHA & Hemaglutynacja & Surowica, osocze & Wynik ujemny \\
\hline Badanie WB w kierunku HCV & Western blot & Surowica, osocze & Wynik ujemny \\
\hline Badanie WB w kierunku HTLV I/II & Western blot & Surowica, osocze & Wynik ujemny \\
\hline Badanie WB w kierunku HIV & Western blot & Surowica, osocze & Wynik ujemny \\
\hline
\end{tabular}

\section{Pracownia Wirusologii Klinicznej}

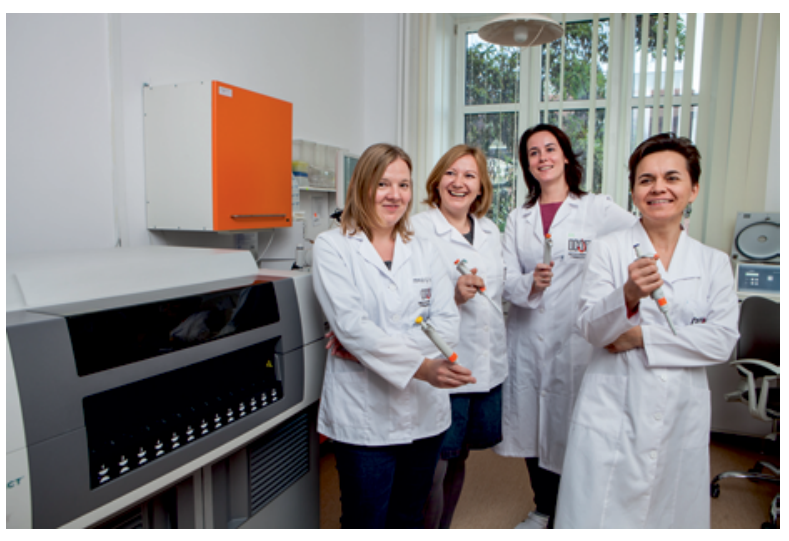

\section{Kierownik: mgr Aleksandra Kalińska}

Zespół: mgr Paula Bryłka, mgr Aneta Klimczak-Plichta, mgr Anna Potępa, mgr Joanna Sierżęga, mgr Paulina Zwolińska

Adres: ul. Chocimska 5, 00-957 Warszawa

tel. 223496644

faks 223496603

e-mail: akalinska@ihit.waw.pl

Badania wykonywane w Pracowni Wirusologii Klinicznej wymieniono w poniższej tabeli. 


\begin{tabular}{|c|c|c|c|c|}
\hline \multirow{4}{*}{ 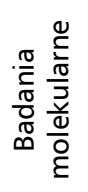 } & Oznaczenie & Metoda & Materiał & Wartości referencyjne \\
\hline & DNA EBV ilościowo/(cito) & Real-time PCR & Krew pełna & Wynik ujemny \\
\hline & DNA CMV ilościowo/(cito) & Real-time PCR & Krew pełna, mocz & Wynik ujemny \\
\hline & DNA B19V ilościowo/(cito) & Real-time PCR & Surowica, osocze & Wynik ujemny \\
\hline \multirow{28}{*}{ 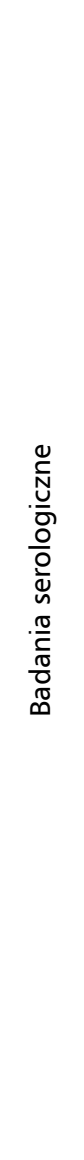 } & DNA BKV półilościowo/(cito) & Real-time PCR & Mocz, krew pełna & Wynik ujemny \\
\hline & HBs Ag & CMIA & Surowica, osocze & Wynik ujemny \\
\hline & Anty-HBc total & CMIA & Surowica, osocze & Wynik ujemny \\
\hline & Anty-HBc IgM & CMIA & Surowica, osocze & Wynik ujemny \\
\hline & $\mathrm{HBe} \mathrm{Ag}$ & CMIA & Surowica, osocze & Wynik ujemny \\
\hline & Anty-HBe & CMIA & Surowica, osocze & Wynik ujemny \\
\hline & Anty-HBs & CMIA & Surowica, osocze & Wynik ujemny \\
\hline & Anty-HCV & CMIA & Surowica, osocze & Wynik ujemny \\
\hline & HIV Ag/Ab & CMIA & Surowica, osocze & Wynik ujemny \\
\hline & Anty-Treponema pallidum & CMIA & Surowica, osocze & Wynik ujemny \\
\hline & Anty-CMV IgG & CMIA & Surowica, osocze & Wynik ujemny \\
\hline & Anty-CMV IgM & CMIA & Surowica, osocze & Wynik ujemny \\
\hline & Anty-Toxo IgG & CMIA & Surowica, osocze & Wynik ujemny \\
\hline & Anty-Toxo IgM & CMIA & Surowica, osocze & Wynik ujemny \\
\hline & Anty-EBV IgM & CMIA & Surowica, osocze & Wynik ujemny \\
\hline & Anty-EBV IgG & CMIA & Surowica, osocze & Wynik ujemny \\
\hline & Anty-EBV EBNA IgG & CMIA & Surowica, osocze & Wynik ujemny \\
\hline & Anty-HTLV I/II & CMIA & Surowica, osocze & Wynik ujemny \\
\hline & Anty-B19V IgG & ELISA & Surowica, osocze & Wynik ujemny \\
\hline & Anty-B19V IgM & ELISA & Surowica, osocze & Wynik ujemny \\
\hline & Anty-HBc total (cito) & CMIA & Surowica, osocze & Wynik ujemny \\
\hline & Anty-HBc IgM (cito) & CMIA & Surowica, osocze & Wynik ujemny \\
\hline & HBe Ag (cito) & CMIA & Surowica, osocze & Wynik ujemny \\
\hline & Anty-HBe (cito) & CMIA & Surowica, osocze & Wynik ujemny \\
\hline & Anty-HTLV I/II (cito) & CMIA & Surowica, osocze & Wynik ujemny \\
\hline & Anty-B19V IgG (cito) & ELISA & Surowica, osocze & Wynik ujemny \\
\hline & Anty-B19V IgM (cito) & ELISA & Surowica, osocze & Wynik ujemny \\
\hline & Test potwierdzenia HBsAg & CMIA & Surowica, osocze & Wynik ujemny \\
\hline
\end{tabular}

*Do badań technikami biologii molekularnej nie należy pobierać krwi na antykoagulant będący inhibitorem reakcji PCR, np. na heparynę

\section{Pracownia Kontroli Jakości i Analiz}

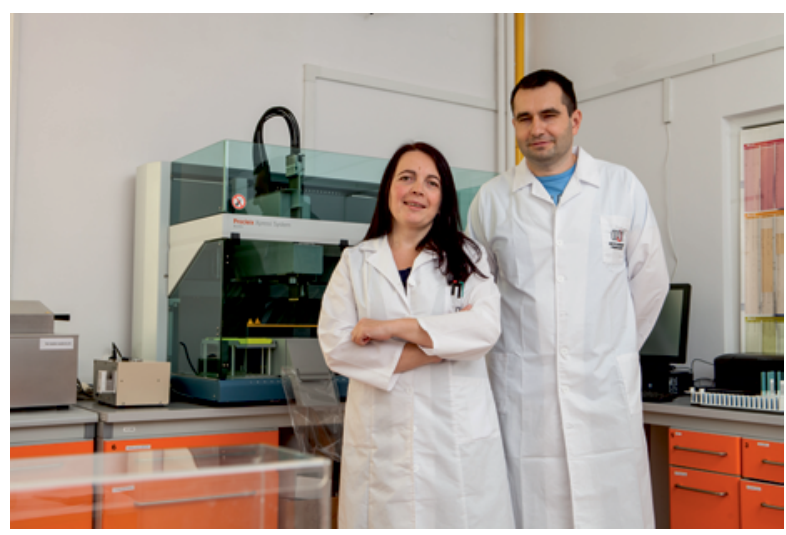

Kierownik: mgr Aneta Kopacz

Zespół: mgr Dorota Kubicka-Russel, mgr Grzegorz Liszewski

Adres: ul. Chocimska 5, 00-957 Warszawa

tel. 223496646

faks 223496603

e-mail: akopacz@ihit.waw.pl
Pracownia prowadzi badania służące ocenie aparatury, metod i testów do badań czynników zakaźnych pod kątem ich przydatności do wykonywania badań przeglądowych u krwiodawców. W Pracowni są prowadzone analizy epidemiologiczne, między innymi częstości wykrywania zakażeń wirusami (HBV, HCV, HIV) u dawców krwi i jej składników. Analizowane są wyniki wirusologicznych badań krwiodawców i pacjentów, u których wykryto zakażenie, między innymi ustala się fazę zakażenia oraz powszechność form polimorficznych wyżej wymienionych wirusów wykrywanych w Polsce.

W Pracowni przygotowuje się panele próbek służących do walidacji i sprawdzianów kontroli jakości metod wprowadzanych i stosowanych w pracowniach czynników zakaźnych przenoszonych przez krew jednostek organizacyjnych publicznej służby krwi. W Pracowni wykonywane są analizy i oceny otrzymywanych wyników badań tych paneli. 


\section{ZAKŁAD RADIOLOGII}

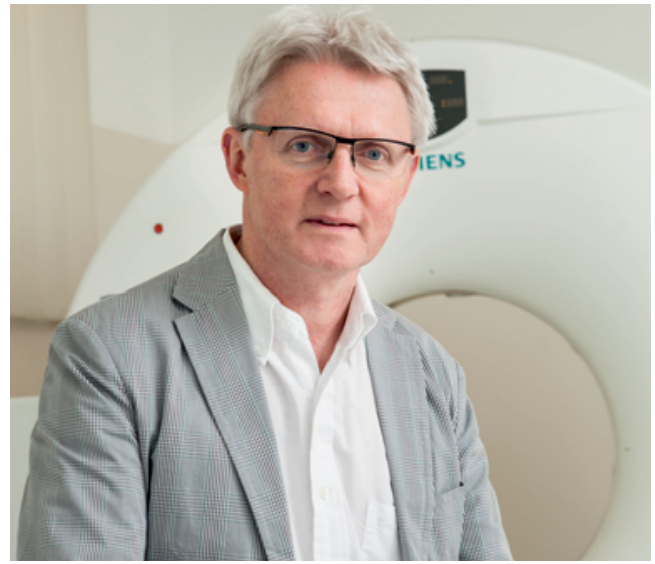

Kierownik: prof. dr hab. n. med. Andrzej Cieszanowski Lekarze: dr n. med. Andrzej Juszyński, lek. Jacek Proniewski, lek. Jerzy Wójtowicz, lek. Janina Żulewska Technicy: st. tech. Aleksandra Cieślak, st. tech. Małgorzata Czajkowska, st. tech. Gabriela Michałowska, st. tech. Krystyna Wiśniewska, tech. Kamil Węgrzycki Sekretariat: Elżbieta Dłutek

\section{Rejestracja: Andrzej Markowicz}

Pielęgniarki: Jadwiga Siwiec, Hanna Ziemczyk

Zakład prowadzi działalność usługową i naukową w dziedzinie radiologii diagnostycznej

Adres: ul. Indiry Gandhi 14, 02-776 Warszawa tel. 223496450

e-mail: edlutek@ihit.waw.pl

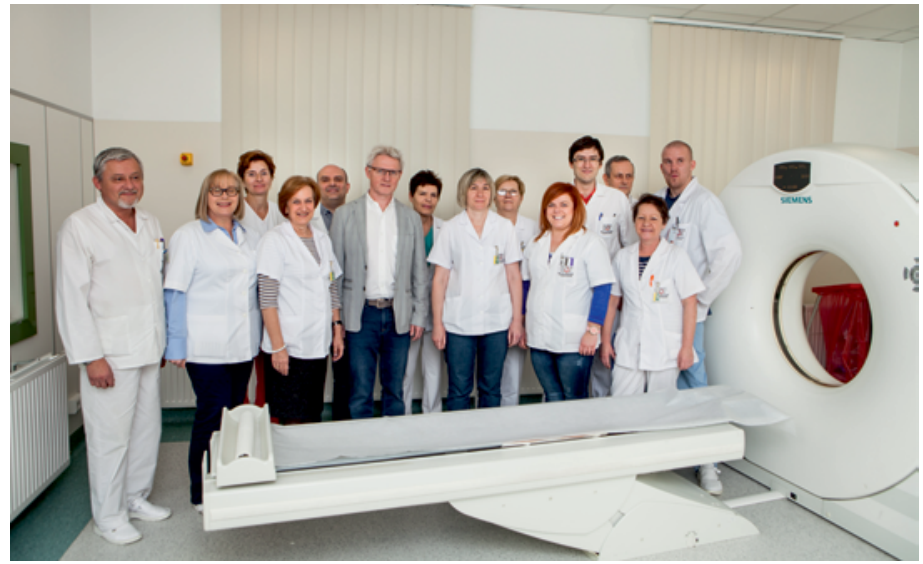

i zabiegowej, a także prowadzi szkolenia i udziela konsultacji w tym zakresie. Ma bogatą i nowoczesną infrastrukturę $\mathrm{i}$ aparaturę pozwalającą na prowadzenie diagnostyki i realizację badań naukowych. Wszystkie aparaty działają w systemie cyfrowym, a pełna informatyzacja pozwala na elektroniczną archiwizację badań.

W Zakładzie są przeprowadzane diagnostyczne badania obrazowe techniką radiologiczną, tomografii komputerowej i ultrasonografii (USG) oraz angiografii tomografii komputerowej, flebografii i USG metodą Dopplera.

W skład Zakładu wchodzą Pracownia Radiologii Ogólnej i Ultrasonografii oraz Pracownia Tomografii Komputerowej. 


\section{ZAKŁAD HEMATOLOGII EKSPERYMENTALNEJ}

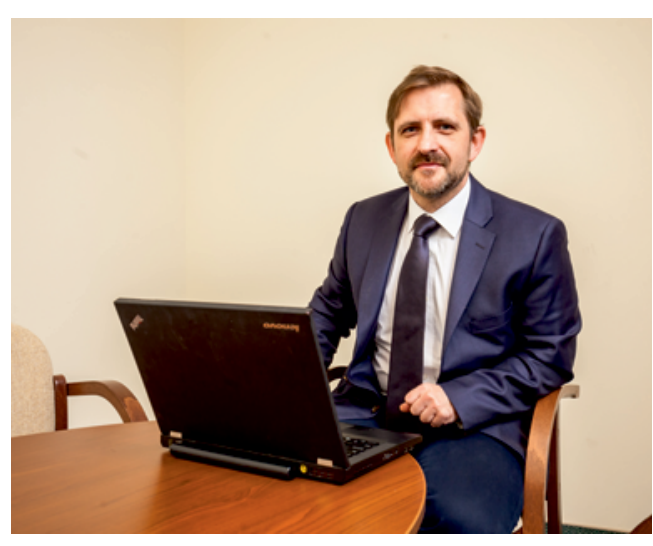

Kierownik: dr hab. n. med. Przemysław Juszczyński, prof. nadzw.

Zastępca kierownika: dr n. biol. Maciej Szydłowski

Adiunkci: dr n. biol. Emilia Białopiotrowicz,

dr n. med. Patryk Górniak, dr n. biol. Ewa Jabłońska, dr n. med. Anna Polak

Biolodzy: mgr Monika Noyszewska-Kania, mgr Karolina Piechna

Alumni: dr Tomasz Sewastianik, dr Przemysław Kiliszek Sekretariat: mgr Monika Milczarek-Szpak

Zakład Hematologii Eksperymentalnej powstał w 2016 roku z przekształcenia Pracowni Hematologii Doświadczalnej Zakładu Diagnostyki Hematologicznej w samodzielną jednostkę organizacyjną. Działalność i kadra Zakładu stanowią zatem rozszerzenie i kontynuację Pracowni powołanej do istnienia w 2011 roku. Utworzenie Pracowni i rekrutacja członków Zespołu były możliwe dzięki inwestycjom Instytutu oraz grantom Fundacji na Rzecz Nauki Polskiej (TEAM) i Narodowego Centrum Nauki, uzyskanym w 2011 roku.

Od początku swej działalności zespól prowadzi badania naukowe dotyczące patogenezy nowotworów układów krwiotwórczego i chłonnego, ze szczególnym uwzględnieniem molekularnej heterogenności chłoniaków B-komórkowych, czynników warunkujących ich wzrost oraz identyfikacji racjonalnych terapii celowanych. Głównym kierunkiem działalności Zakładu są molekularne mechanizmy transmisji sygnału receptora B-komórkowego w komórkach nowotworowych chłoniaków rozlanych $z$ dużych komórek B oraz identyfikacja optymalnych strategii terapeutycznych prowadzących do blokady sygnału i przerwania jego antyapoptotycznego działania

Drugim kierunkiem działania Zakładu są molekularne mechanizmy onkogennej aktywności kinaz PIM i zdefiniowanie potencjalnych zastoso-

Adres: ul. Indiry Gandhi 14, 02-776 Warszawa tel.: 223496 517; 223496 518; 223496305 e-mail: pjuszczynski@ihit.waw.pl wań terapeutycznych ich celowanych inhibitorów. Pracownia prowadzi również badania dotyczące oporności komórek ostrych białaczek limfoblastycznych na stosowane chemioterapeutyki i celowane metody farmakologicznego uwrażliwienia blastów na konwencjonalne cytostatyki. Wyniki tych badań są publikowane w prestiżowych czasopismach i znajdują szeroki oddźwięk w licznych cytowaniach oraz krajowych i zagranicznych wyróżnieniach dla członków zespołu.

Pracownie Zakładu w swoich pracach wykorzystują szerokie spektrum technik biologii molekularnej, biochemii i bioinformatyki, ukierunkowanych na dogłębną funkcjonalną weryfikację stawianych pytań i hipotez. Przy realizacji badań Zakład ściśle współpracuje $z$ Kliniką Hematologii oraz Zakładem Diagnostyki Hematologicznej. Szczególnym zasobem infrastrukturalnym, w znacznej mierze przeznaczonym do pracy naukowej, jest Laboratorium Cyfrowej Patologii („Cyfralab”) (http://www. cyfrowelaboratorium.ihit.waw.pl). Laboratorium Cyfrowej Patologii stanowi zintegrowany system obejmujący aparaturę badawczą pozwalającą między innymi na konstrukcję multibloków, zautomatyzowane barwienia, akwizycję i cyfrową analizę obrazu, mikrodyssekcję laserową; infrastrukturę tę uzupełnia system informatyczny integrujący moduły systemu i obejmujący ponadto cyfrową bibliotekę obrazów oraz bank świeżych i utrwalonych tkanek.

Badania naukowe podejmowane w Zakładzie $\mathrm{w}$ większości są oparte na finansowaniu $z$ grantów Fundacji na Rzecz Nauki Polskiej, Narodowego Centrum Nauki i Narodowego Centrum Badań i Rozwoju. Od 2015 roku Zespół Zakładu prowadzi badania realizowane w ramach projektów Strategmed I i II, których celem jest opracowanie i wdrożenie innowacyjnych terapii ukierunkowanych w nowotworach układów krwiotwórczego i chłonnego.

W skład Zakładu wchodzą Pracownie: Nowotworów Układu Chłonnego, Nowotworów Układu Krwiotwórczego, Immunologii Nowotworów oraz Genetyki i Biologii Obliczeniowej. 
Pracownia Nowotworów Układu Chłonnego

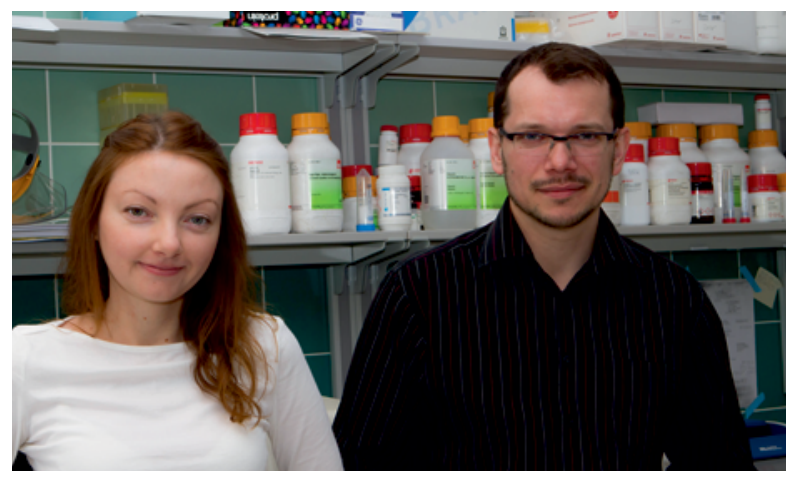

Kierownik: dr n. biol. Maciej Szydłowski

Zespół: dr Anna Polak

Adres: ul. Indiry Gandhi 14, 02-776 Warszawa

tel.: 223496 517; 223496 518; 223496305

e-mail: mszydlowski@ihit.waw.pl

Działalność Pracowni jest skupiona na mechanizmach patogenetycznych i identyfikacji celów terapeutycznych w nowotworach B-komórkowych. Priorytetowe kierunki badań dotyczą mechanizmów przekazywania i efektorów sygnału receptora B-komórkowego. Drugim kierunkiem badań jest rola kinaz PIM w tych nowotworach. Trzeci kierunek badań stanowią mechanizmy oporności na leki w ostrej białaczce limfoblastycznej oraz charakterystyka populacji komórek klonogennych.

\section{Pracownia Nowotworów Układu Krwiotwórczego}

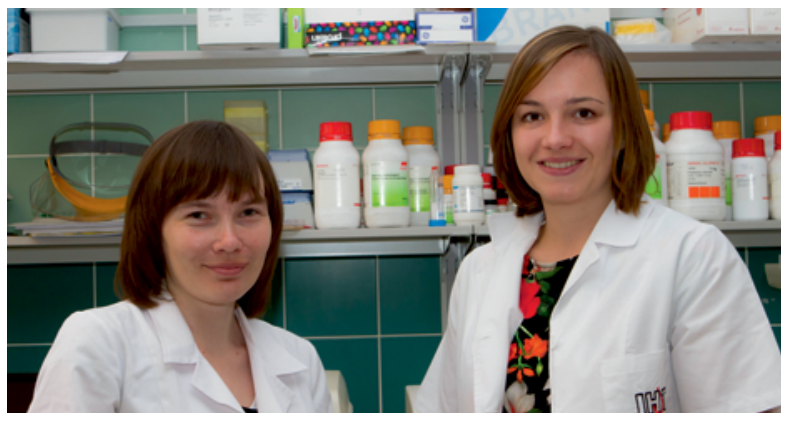

Kierownik: dr n. biol. Emilia Białopiotrowicz Zespół: mgr Monika Noyszewska-Kania Adres: ul. Indiry Gandhi 14, 02-776 Warszawa tel.: 223496 517; 223496 518; 223496305 e-mail: ebialopiotrowicz@ihit.waw.pl

W Pracowni poszukuje się nowych mechanizmów epigenetycznych i metabolicznych w nowotworach układu krwiotwórczego, których celowana inhibicja może stanowić nową strategię terapeutyczną. Ponadto są prowadzone badania dotyczące mechanizmów warunkujących potencjał samoodnowy białaczkowych komórek macierzystych.

\section{Pracownia Immunologii Nowotworów}

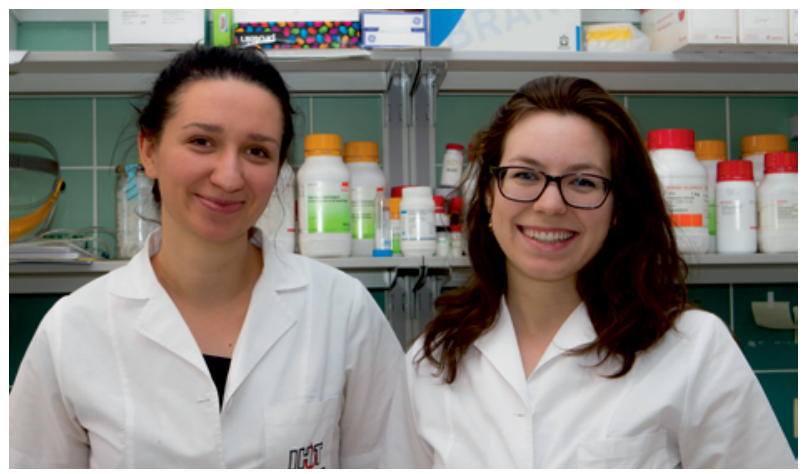

Kierownik: dr n. biol. Ewa Jabłońska

Zespół: mgr Karolina Piechna

Adres: ul. Indiry Gandhi 14, 02-776 Warszawa

tel.: 223496 517; 223496 518; 223496305

e-mail: ejablonska@ihit.waw.pl

W Pracowni są rozwijane nowe strategie immunoterapii $\mathrm{w}$ nowotworach układów chłonnego i krwiotwórczego. Badania te są realizowane w szerokiej współpracy międzyośrodkowej w ramach programu Strategmed. Pracownia współpracuje ponadto $z$ pozostałymi pracowniami Zakładu, Kliniką Hematologii i Zakładem Diagnostyki Hematologicznej w zakresie technik immunologicznych wykorzystywanych w badaniach nad nowotworami układów krwiotwórczego i chłonnego.

\section{Pracownia Genetyki i Biologii Obliczeniowej}

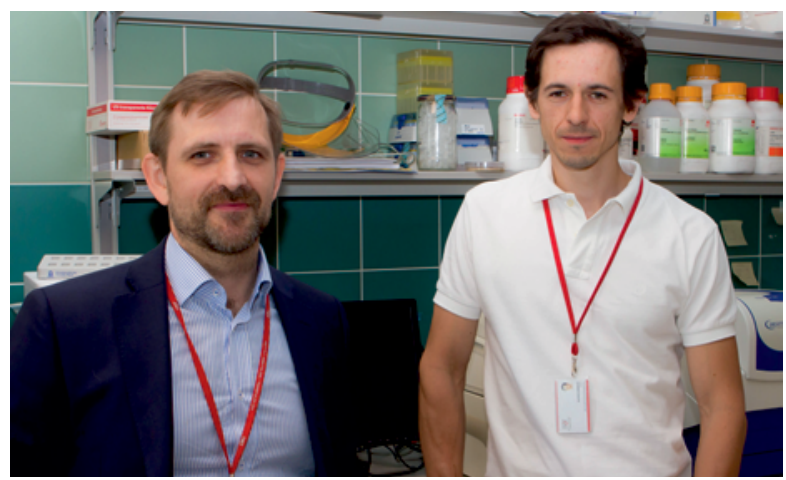

Kierownik: dr n. biol. Patryk Górniak

Adres: ul. Indiry Gandhi 14, 02-776 Warszawa tel.: 223496 517; 223496 518; 223496305 e-mail:pgorniak@ihit.waw.pl

Pracownia współpracuje $z$ pozostałymi pracowniami Zakładu w zakresie technik bioinformatycznych i analiz wielkoskalowych na potrzeby realizowanych projektów, a ponadto stanowi zaplecze naukowe dla opracowywania i weryfikacji nowych metod badań diagnostycznych $z$ zastosowaniem technik genetyki i biologii molekularnej. 